Prepared in cooperation with the Rosebud Sioux Tribe

\title{
Conceptual and Numerical Models of Groundwater Flow in the Ogallala Aquifer in Gregory and Tripp Counties, South Dakota, Water Years 1985-2009
}

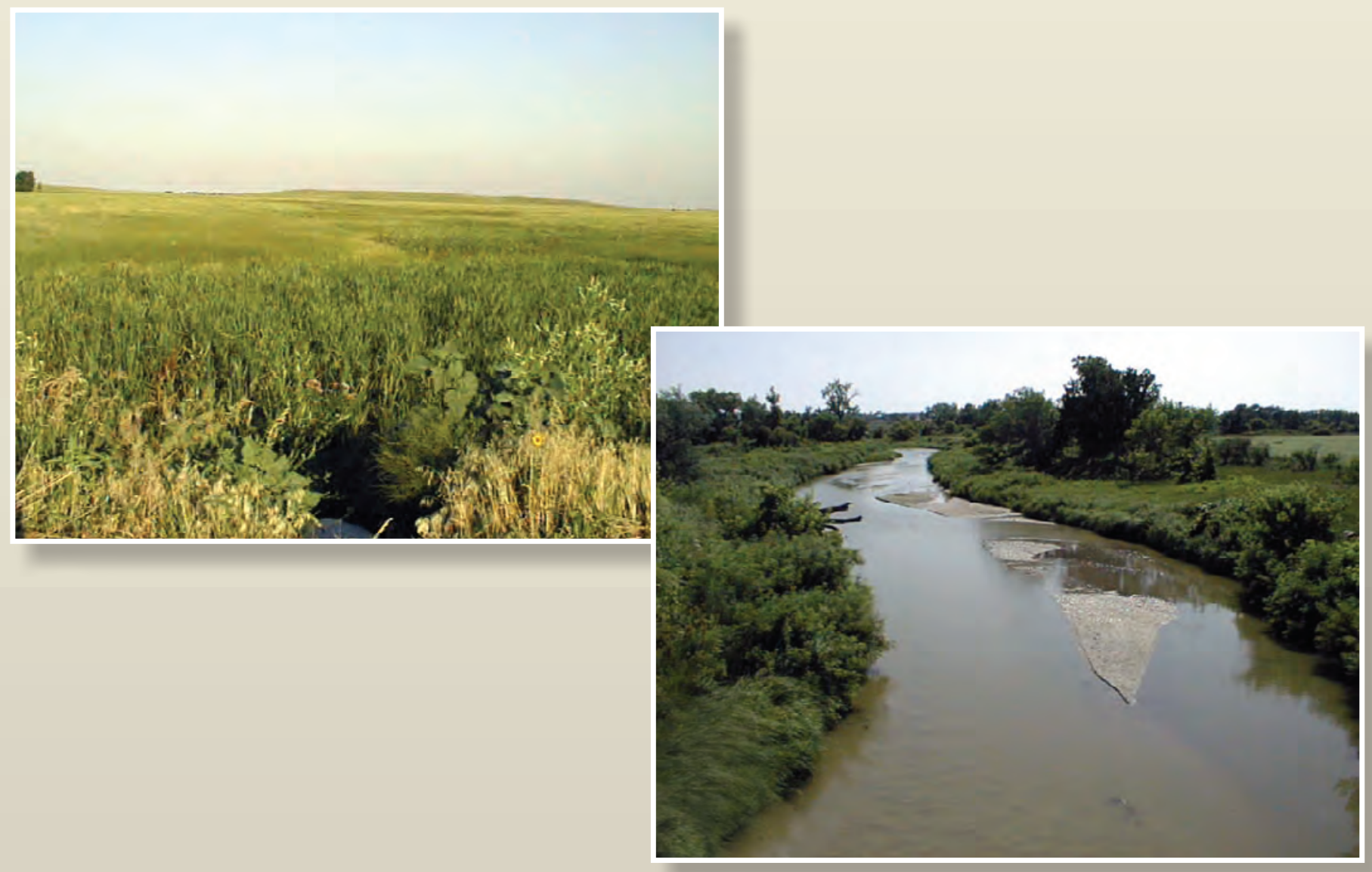

Scientific Investigations Report 2013-5069 
Cover. Left photograph: Sand Creek near Olsonville, South Dakota (streamgage 06464120). Sand Creek is a tributary to the Keya Paha River and is fed by seeps or springs that originate from the Ogallala aquifer. Photograph taken on October 12, 2005, by Brad Kniss, U.S. Geological Survey.

Right photograph: Keya Paha River at Wewela, South Dakota (streamgage 06464500). Groundwater discharge from the Ogallala aquifer provides base flow to the Keya Paha River. Photograph taken on July 17, 2006, by Brad Kniss, U.S. Geological Survey. 


\section{Conceptual and Numerical Models of Groundwater Flow in the Ogallala Aquifer in Gregory and Tripp Counties, South Dakota, Water Years 1985-2009}

By Kyle W. Davis and Larry D. Putnam

Prepared in cooperation with the Rosebud Sioux Tribe

Scientific Investigations Report 2013-5069 


\title{
U.S. Department of the Interior SALLY JEWELL, Secretary
}

\section{U.S. Geological Survey Suzette M. Kimball, Acting Director}

\author{
U.S. Geological Survey, Reston, Virginia: 2013
}

For more information on the USGS - the Federal source for science about the Earth, its natural and living resources, natural hazards, and the environment, visit http://www.usgs.gov or call 1-888-ASK-USGS.

For an overview of USGS information products, including maps, imagery, and publications, visit http://www.usgs.gov/pubprod

To order this and other USGS information products, visit http://store.usgs.gov

Any use of trade, firm, or product names is for descriptive purposes only and does not imply endorsement by the U.S. Government.

Although this information product, for the most part, is in the public domain, it also may contain copyrighted materials as noted in the text. Permission to reproduce copyrighted items must be secured from the copyright owner.

Suggested citation:

Davis, K.W., and Putnam, L.D., 2013, Conceptual and numerical models of groundwater flow in the Ogallala aquifer in Gregory and Tripp Counties, South Dakota, water years 1985-2009: U.S. Geological Survey Scientific Investigations Report 2013-5069, 82 p., http://pubs.usgs.gov/sir/2013/5069/. 


\section{Acknowledgments}

The authors would like to recognize important contributions made by the Rosebud Sioux Tribe to the development of the groundwater-flow model described in this report. Development of a calibrated numerical model resulted from the tribe's long-term commitment to obtaining hydrologic information. The tribe was actively involved in the design of the study, the conceptualization of the groundwater-flow system, the technical evaluation of model performance, and the review of this report. The South Dakota Department of Environment and Natural Resources Geological Survey lithologic database was the primary source of data for interpretation of the hydrogeologic framework. The Water Rights Program of the South Dakota Department of Environment and Natural Resources provided permitting and water-use data and long-term water-level data for their groundwater monitoring network in the study area. 


\section{Contents}

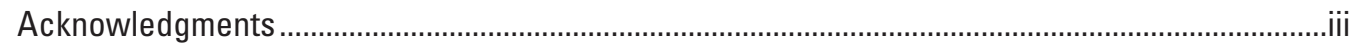

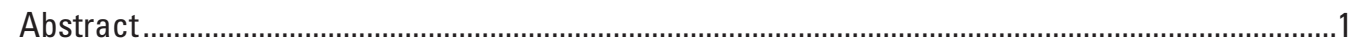

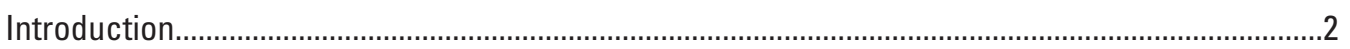

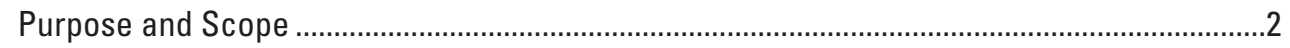

Previous Investigations......................................................................................................

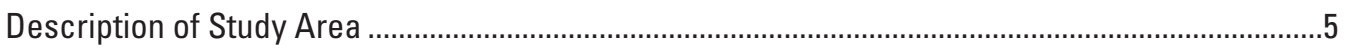

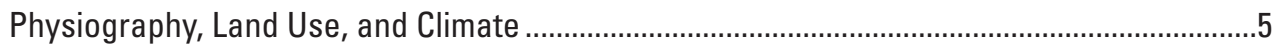

Drainage Features and Streamflow...............................................................................

Geology

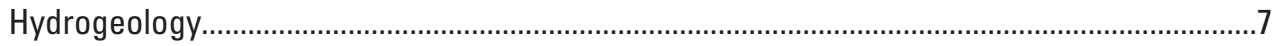

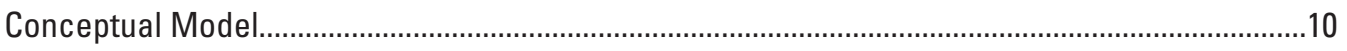

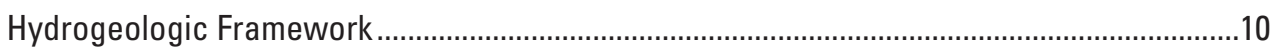

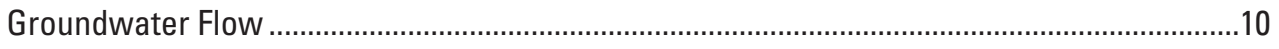

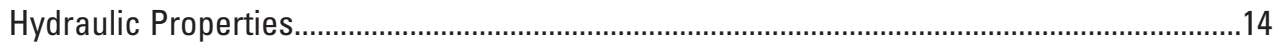

Water Budget Components ..........................................................................................16

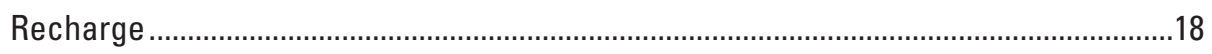

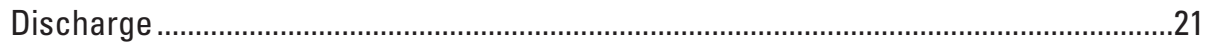

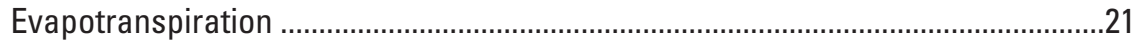

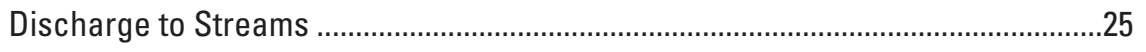

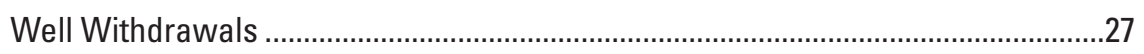

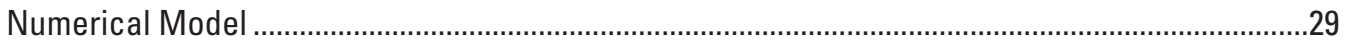

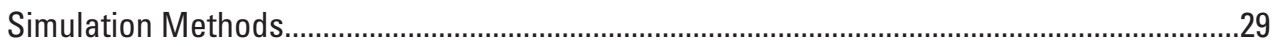

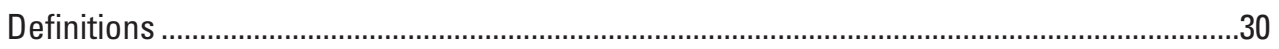

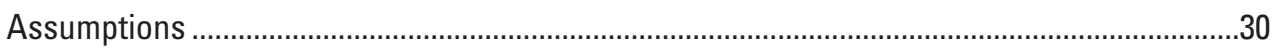

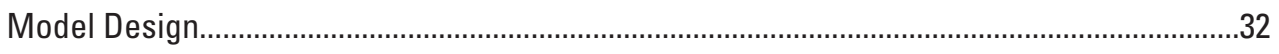

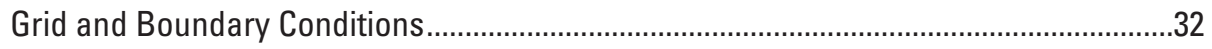

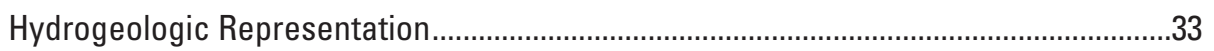

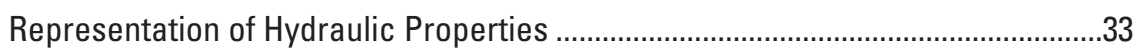

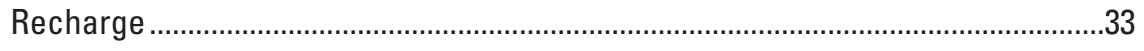

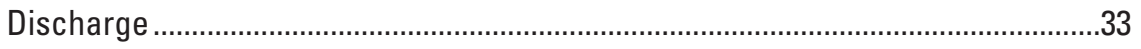

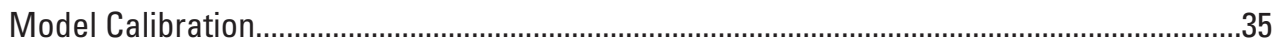

Calibration Targets...................................................................................................

Calibrated Parameter Values..........................................................................................38

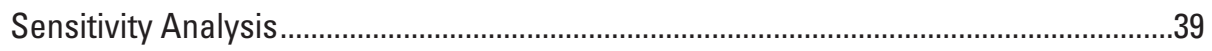

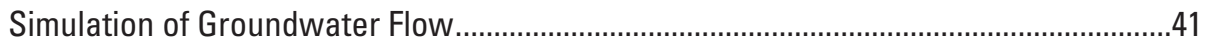

Initialization Period .......................................................................................... 41

Transient Simulation ..............................................................................................

Simulation of Future Scenarios ......................................................................................

Comparison of Simulated Groundwater Budgets.........................................................48

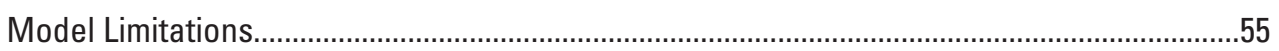

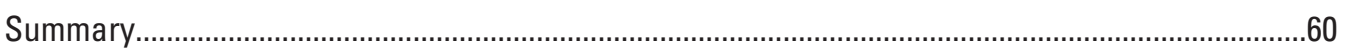

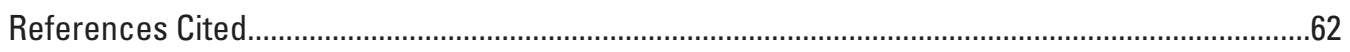




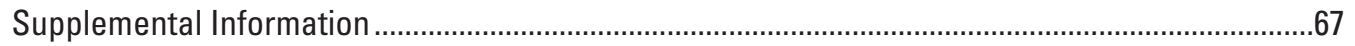

Supplement 1. Data Used to Estimate Mean Potentiometric Surface .............................................68

Supplement 2. Estimates of Transmissivity and Hydraulic Conductivity from Specific Capacity Data ..................................................................................................................

Supplement 3. Analysis of Recharge and Evapotranspiration With a Soil-Water-Balance

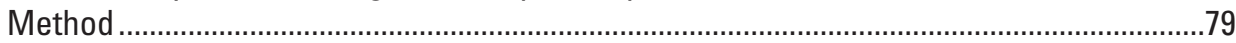

\section{Figures}

1. Map showing study area, extent of the northern High Plains aquifer, and location of main physiographic divisions ................................................................................................

2. Map showing location and altitude of the study area...................................................

3. Map showing drainage basins and generalized land cover in the study area .................6

4. Map showing generalized surface geology in the study area.........................................

5. Map showing estimated mean saturated thickness of the Ogallala aquifer in the study area

6. Map showing the location of South Dakota Department of Environment and Natural Resources observation wells, test holes, and individual wells used to estimate the mean potentiometric surface of the Ogallala aquifer in the study area.

7. Map showing estimated mean potentiometric surface of the Ogallala aquifer in the study area, water years 1985-2009.

8. Graph showing generalized relationship between hydraulic head, hydrogeologic units, and topographic features for cross-section $A-A^{\prime}$.

9. Map showing the altitude of the base of the Ogallala aquifer in the study area.............17

10. Map showing calculated specific capacity of selected wells completed in the Ogallala aquifer and estimated hydraulic conductivity of the aquifer in the study area

11. Map showing the locations of climate stations and streamgages in and around the study area

12. Map showing the spatial distribution of mean annual recharge to the Ogallala aquifer in the study area for water years 1985-2009 estimated with the soil-water-balance method

13. Map showing production wells completed in the Ogallala aquifer in the study area

14. Map showing the numerical model grid design for the study area and boundary conditions used to simulate groundwater flow in the Ogallala aquifer.

15. Map showing pilot-point zones and locations used for representing horizontal hydraulic conductivity in the Ogallala aquifer in the study area .......................................34

16. Map showing model representation of discharge including river cells and drain cells for the Ogallala aquifer in the study area.

17. Map showing calibrated horizontal hydraulic conductivity of the Ogallala aquifer in the study area.

18. Bar graph showing relative composite parameter sensitivities, as defined by Doherty (2010), for the numerical model.

19. Map showing simulated long-term mean potentiometric surface in the Ogallala aquifer in the study area......

20. Map showing difference between the observed and simulated potentiometric surfaces in the study area. 
21. Map showing the mean residuals between observed and simulated hydraulic heads for State observation wells completed in the Ogallala aquifer in the study area, water years $1985-2009$

22. Histogram of residuals of observed and simulated hydraulic head in State observation wells for the Ogallala aquifer in the study area, water years 1985-2009

23. Hydrographs showing observed and simulated hydraulic heads for State observation wells completed in the Ogallala aquifer in the study area

24. Graph showing linear regression of observed and simulated hydraulic heads for State observation wells in the Ogallala aquifer in the study area.

25. Graph showing estimated and simulated base flow from groundwater discharge from the Ogallala aquifer in the study area for the Keya Paha River..

26. Hydrographs showing the difference in hydraulic heads between the results of the calibrated model (non-drought simulation) and the assumed potential drought scenario for the 25-year simulation period for selected State observation wells completed in the Ogallala aquifer in the study area..

27. Map showing the simulated difference in hydraulic head between the calibrated model (non-drought simulation) and the simulation representing a potential drought scenario for the Ogallala aquifer in the study area

28. Map showing the simulated difference in hydraulic head between the calibrated model and the simulation representing a potential increased pumping scenario for the Ogallala aquifer in the study area

S3-1. Map of soil type as defined for recharge calculations in soil-water-balance method in the study area 


\section{Tables}

1. Generalized stratigraphic column showing geologic units west of the Missouri River in study area.

2. Selected data for long-term State observation wells completed in the Ogallala aquifer in Gregory and Tripp Counties .

3. Previously published hydraulic properties within or near the study area .......................18

4. Recharge to the Ogallala aquifer in the study area estimated by using the soil-water-balance method, water years 1985-2009...

5. Measured pan evaporation at Pickstown, South Dakota, and maximum potential evapotranspiration estimated by using the soil-water-balance method, water years 1985-2009.

6. Discharge to the Keya Paha River as base flow estimated using hydrograph separation, water years 1985-2009

7. Estimated withdrawals from the Ogallala aquifer for irrigation use in the study area, water years 1985-2009

8. Estimated per capita use and withdrawals from the Ogallala aquifer for public supply in the study area

9. Estimated discharge components from the Ogallala aquifer as base flow to the Keya Paha River between streamgages at Keyapaha and Wewela, South Dakota, for the for the initialization stress period...

10. Calibrated horizontal hydraulic conductivity for pilot points used in numerical model 38

11. Calibrated parameters for the numerical model

12. Water budget for the numerical model simulating long-term mean conditions compared with flow estimates from the conceptual model.

13. Comparison of observed and simulated hydraulic heads for State observation wells for the transient simulation

14. Comparison of estimated to simulated base flow for the Keya Paha River for the transient simulation.

15. Simulated groundwater budget for the initialization period, water years 1985-2009, potential drought scenario, and potential increased pumping scenario for the Ogallala aquifer in the study area

S1-1. Selected data from wells used for mean potentiometric surface of the Ogallala aquifer for water years 1985-2009.

S2-1. Specific capacity data, transmissivity, and hydraulic conductivity for selected wells completed in the Ogallala aquifer in the study area .............................................76

S3-1. Infiltration rates assigned by soil type ..........................................................................

S3-2. Interception storage values and depth of root zone assigned by land-cover category 


\section{Conversion Factors}

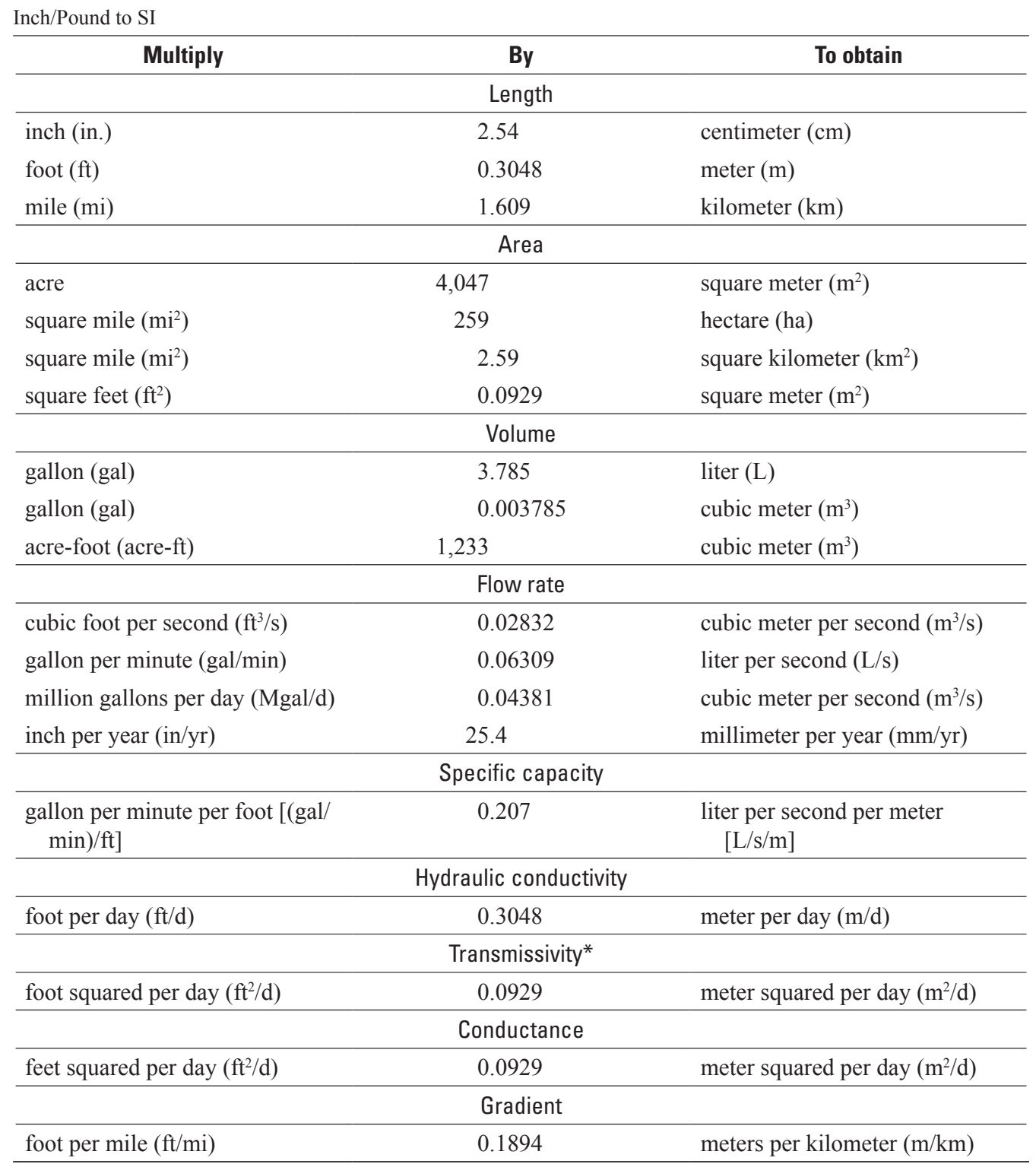

Temperature in degrees Fahrenheit $\left({ }^{\circ} \mathrm{F}\right)$ may be converted to degrees Celsius $\left({ }^{\circ} \mathrm{C}\right)$ as follows:

${ }^{\circ} \mathrm{C}=\left({ }^{\circ} \mathrm{F}-32\right) / 1.8$

Vertical coordinate information is referenced to the National Geodetic Vertical Datum of 1929 (NGVD 29).

Horizontal coordinate information is referenced to the North American Datum of 1983 (NAD 83).

Altitude, as used in this report, refers to distance above the vertical datum. 
*Transmissivity: The standard unit for transmissivity is cubic foot per day per square foot times foot of aquifer thickness $\left[\left(\mathrm{ft}^{3} / \mathrm{d}\right) / \mathrm{ft}^{2}\right] \mathrm{ft}$. In this report, the mathematically reduced form, foot squared per day $\left(\mathrm{ft}^{2} / \mathrm{d}\right)$, is used for convenience.

A water year (WY) is the 12-month period from 0ctober 1 through September 30 and is designated by the calendar year in which it ends.

\section{Abbreviations}

$\begin{array}{ll} \pm & \text { plus or minus } \\ \text { DEM } & \text { digital elevation model } \\ \text { GIS } & \text { geographic information system } \\ \text { NED } & \text { National Elevation Dataset (U.S. Geological Survey) } \\ \text { NOAA } & \text { National Oceanic and Atmospheric Administration } \\ \text { PEST } & \text { Parameter Estimation } \\ \text { RASA } & \text { Regional Aquifer-System Analysis (U.S. Geological Survey) } \\ \text { SDDENR } & \text { South Dakota Department of Environment and Natural Resources } \\ \text { SWB } & \text { Soil-Water Balance (software program) or soil-water balance } \\ \text { SWUDS } & \text { Site-specific Water-Use Data System (U.S. Geological Survey) } \\ \text { UPW } & \text { Upstream Weighting (MODFLOW-NWT solver package) } \\ \text { USGS } & \text { U.S. Geological Survey } \\ \text { WY } & \text { water year }\end{array}$





\title{
Conceptual and Numerical Models of Groundwater Flow in the Ogallala Aquifer in Gregory and Tripp Counties, South Dakota, Water Years 1985-2009
}

\author{
By Kyle W. Davis and Larry D. Putnam
}

\section{Abstract}

The Ogallala aquifer is an important water resource for the Rosebud Sioux Tribe in Gregory and Tripp Counties in south-central South Dakota and is used for irrigation, public supply, domestic, and stock water supplies. To better understand groundwater flow in the Ogallala aquifer, conceptual and numerical models of groundwater flow were developed for the aquifer. A conceptual model of the Ogallala aquifer was used to analyze groundwater flow and develop a numerical model to simulate groundwater flow in the aquifer. The MODFLOWNWT model was used to simulate transient groundwater conditions for water years 1985-2009. The model was calibrated using statistical parameter estimation techniques. Potential future scenarios were simulated using the input parameters from the calibrated model for simulations of potential future drought and future increased pumping.

Transient simulations were completed with the numerical model. A 200-year transient initialization period was used to establish starting conditions for the subsequent 25-year simulation of water years 1985-2009. The 25-year simulation was discretized into three seasonal stress periods per year and used to simulate transient conditions.

A single-layer model was used to simulate flow and mass balance in the Ogallala aquifer with a grid of 133 rows and 282 columns and a uniform spacing of 500 meters (1,640 feet). Regional inflow and outflow were simulated along the western and southern boundaries using specified-head cells. All other boundaries were simulated using no-flow cells. Recharge to the aquifer occurs through precipitation on the outcrop area.

Model calibration was accomplished using the Parameter Estimation (PEST) program that adjusted individual model input parameters and assessed the difference between estimated and model-simulated values of hydraulic head and base flow. This program was designed to estimate parameter values that are statistically the most likely set of values to result in the smallest differences between simulated and observed values, within a given set of constraints. The potentiometric surface of the aquifer calculated during the 200-year initialization period established initial conditions for the transient simulation. Water levels for 38 observation wells were used to calibrate the 25-year simulation. Simulated hydraulic heads for the transient simulation were within plus or minus 20 feet of observed values for 95 percent of observation wells, and the mean absolute difference was 5.1 feet. Calibrated hydraulic conductivity ranged from 0.9 to 227 feet per day.

The annual recharge rates for the transient simulation (water years 1985-2009) ranged from 0.60 to 6.96 inches, with a mean of 3.68 inches for the Ogallala aquifer. This represents a mean recharge rate of $280.5 \mathrm{ft}^{3} / \mathrm{s}$ for the model area. Discharge from the aquifer occurs through evapotranspiration, discharge to streams through river leakage and flow from springs and seeps, and well withdrawals. Water is withdrawn from wells for irrigation, public supply, domestic, and stock uses. Simulated mean discharge rates for water years 1985-2009 were about 185 cubic feet per second $\left(\mathrm{ft}^{3} / \mathrm{s}\right)$ for evapotranspiration, $66.7 \mathrm{ft}^{3} / \mathrm{s}$ for discharge to streams, and $5.48 \mathrm{ft}^{3} / \mathrm{s}$ for well withdrawals. Simulated annual evapotranspiration rates ranged from about 128 to $254 \mathrm{ft}^{3} / \mathrm{s}$, and outflow to streams ranged from 52.2 to $79.9 \mathrm{ft}^{3} / \mathrm{s}$.

A sensitivity analysis was used to examine the response of the calibrated model to changes in model parameters for horizontal hydraulic conductivity, recharge, evapotranspiration, and spring and riverbed conductance. The model was most sensitive to recharge and maximum potential evapotranspiration and least sensitive to riverbed and spring conductances.

Two potential future scenarios were simulated: a potential drought scenario and a potential increased pumping scenario. To simulate a potential drought scenario, a synthetic drought record was created, the mean of which was equal to 60 percent of the mean estimated recharge rate for the 25 -year simulation period. Compared with the results of the calibrated model (non-drought simulation), the simulation representing a potential drought scenario resulted in water-level decreases of as much as 30 feet for the Ogallala aquifer. To simulate the effects of potential future increases in pumping, well withdrawal rates were increased by 50 percent from those estimated for the 25-year simulation period. Compared with the results of the calibrated model, the simulation representing an 
increased pumping scenario resulted in water-level decreases of as much as 26 feet for the Ogallala aquifer.

Groundwater budgets for the potential future scenario simulations were compared with the transient simulation representing water years 1985-2009. The simulation representing a potential drought scenario resulted in lower aquifer recharge from precipitation and decreased discharge from streams, springs, seeps, and evapotranspiration. The simulation representing a potential increased pumping scenario was similar to results from the transient simulation, with a slight increase in well withdrawals and a slight decrease in discharge from river leakage and evapotranspiration.

This numerical model is suitable as a tool that could be used to better understand the flow system of the Ogallala aquifer, to approximate hydraulic heads in the aquifer, and to estimate discharge to rivers, springs, and seeps in the study area. The model also is useful to help assess the response of the aquifer to additional stresses, including potential drought conditions and increased well withdrawals.

\section{Introduction}

The High Plains aquifer, which includes the Ogallala and Arikaree aquifers, underlies almost 112 million acres in the central United States (Stanton and others, 2011). The High Plains aquifer underlies parts of eight States and extends from southern South Dakota to Texas (fig. 1). The aquifer has been used extensively for irrigation, public supply, domestic, and stock water use and is an important water supply for the United States. About 2 million people rely on the High Plains aquifer for drinking water with total public supply withdrawals of 418 million gallons per day (Mgal/d; Dennehy, 2000). The High Plains region supplies approximately one-fourth of the Nation's agricultural production (McMahon and others, 2007).

The High Plains aquifer underlies about 4,750 square miles $\left(\mathrm{mi}^{2}\right)$ in south-central South Dakota (Gutentag and others, 1984), including parts of Gregory and Tripp Counties (fig. 2). The Ogallala aquifer overlies the Arikaree aquifer throughout much of this area and is used extensively for irrigation, public supply, domestic, and stock water supplies. Although the Arikaree aquifer is considered part of the High Plains aquifer, it is used much less extensively than the Ogallala aquifer within Gregory and Tripp Counties.

The High Plains aquifer generally is less developed in South Dakota compared with other parts of the Nation underlain by this aquifer, and thus, water levels in the aquifer in South Dakota generally changed less than 5 feet (ft) from 1980 to 1999 (McGuire, 2001). Despite minimal water-level changes in the High Plains aquifer in South Dakota, extensive withdrawals of groundwater for irrigation have caused waterlevel decreases in many parts of the aquifer and increased concerns about the long-term sustainability of the aquifer (Stanton and others, 2011). Since the 1950s, water-level decreases of as much as $100 \mathrm{ft}$ have been measured in parts of Kansas, New
Mexico, Oklahoma, and Texas (Dennehy, 2000). Discharge from the aquifer through springs and seeps provides base flow for several important streams in the area (Carter, 1998; Filipovic, 2004). Therefore, continued or increased withdrawals from the aquifer or prolonged drought may have the potential to affect water levels within the aquifer and discharge to important streams in the area.

The Rosebud Sioux Tribe has identified a need for waterresource tools to analyze the effects of potential increased groundwater demand or prolonged drought and to evaluate potential future management issues associated with the Ogallala aquifer, such as planning for source-water protection, describing potential effects of contamination, and estimating sustainable aquifer withdrawals. A primary tool conceived by the tribe was a numerical groundwater-flow model for the Ogallala aquifer in Gregory and Tripp Counties. Therefore, the U.S. Geological Survey (USGS) has worked in cooperation with the tribe to develop the conceptual and numerical models described in the report.

The numerical model is a water-resource tool used to analyze the groundwater system and can be used to assess water-management issues associated with the Ogallala aquifer in Gregory and Tripp Counties. The model could be used by water managers to evaluate the effects of various hydrologic scenarios, including increased well withdrawals or prolonged drought within the study area.

\section{Purpose and Scope}

This report describes and documents conceptual and numerical models of groundwater flow in the Ogallala aquifer, developed in cooperation with the Rosebud Sioux Tribe. The conceptual and numerical models were developed to describe and simulate groundwater flow in the Ogallala aquifer in Gregory and Tripp Counties in south-central South Dakota. The conceptual model describes the geology, hydrogeology, and groundwater flow for water years (WYs) 1985-2009 (October 1, 1984, through September 30, 2009). A transient numerical model was executed for a 25 -year period of measured data consisting of WYs 1985-2009. This report also documents numerical simulations of two potential future scenarios. The first scenario represented a potential 25 -year drought, and the second scenario represented a potential increase in groundwater withdrawals from existing production wells.

\section{Previous Investigations}

Newport (1959) described the groundwater resources for the lower Niobrara River and Ponca Creek drainage basins, which includes parts of the Ogallala aquifer in Gregory and Tripp Counties, S. Dak. Rahn and Paul (1975) conducted an aquifer test in southeastern Todd County, S. Dak., to determine hydraulic properties of the Ogallala aquifer. Kolm and Case (1983) developed a two-dimensional numerical groundwater model for the High Plains aquifer, which includes the Ogallala 


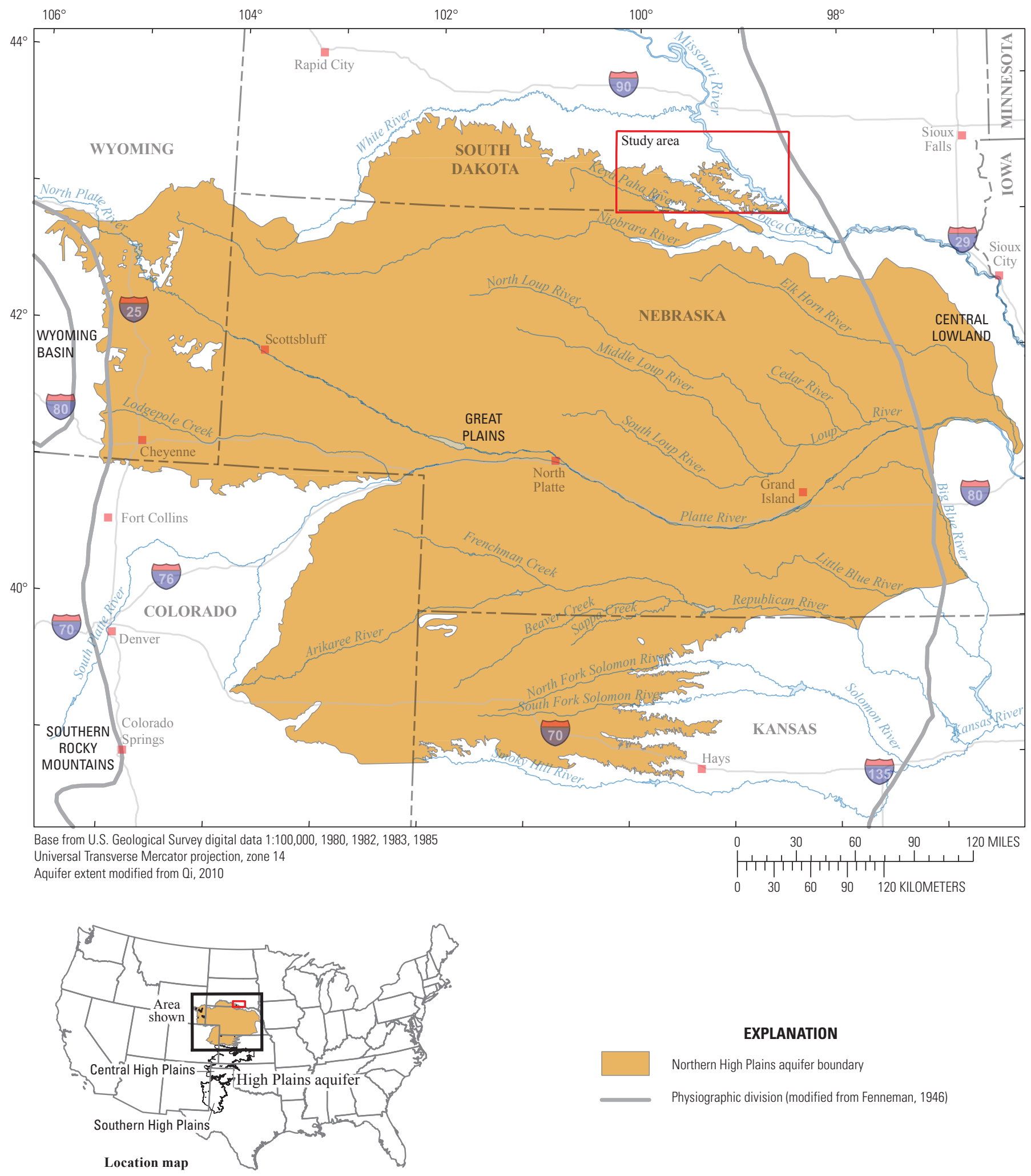

Figure 1. Study area, extent of the northern High Plains aquifer, and location of main physiographic divisions. 


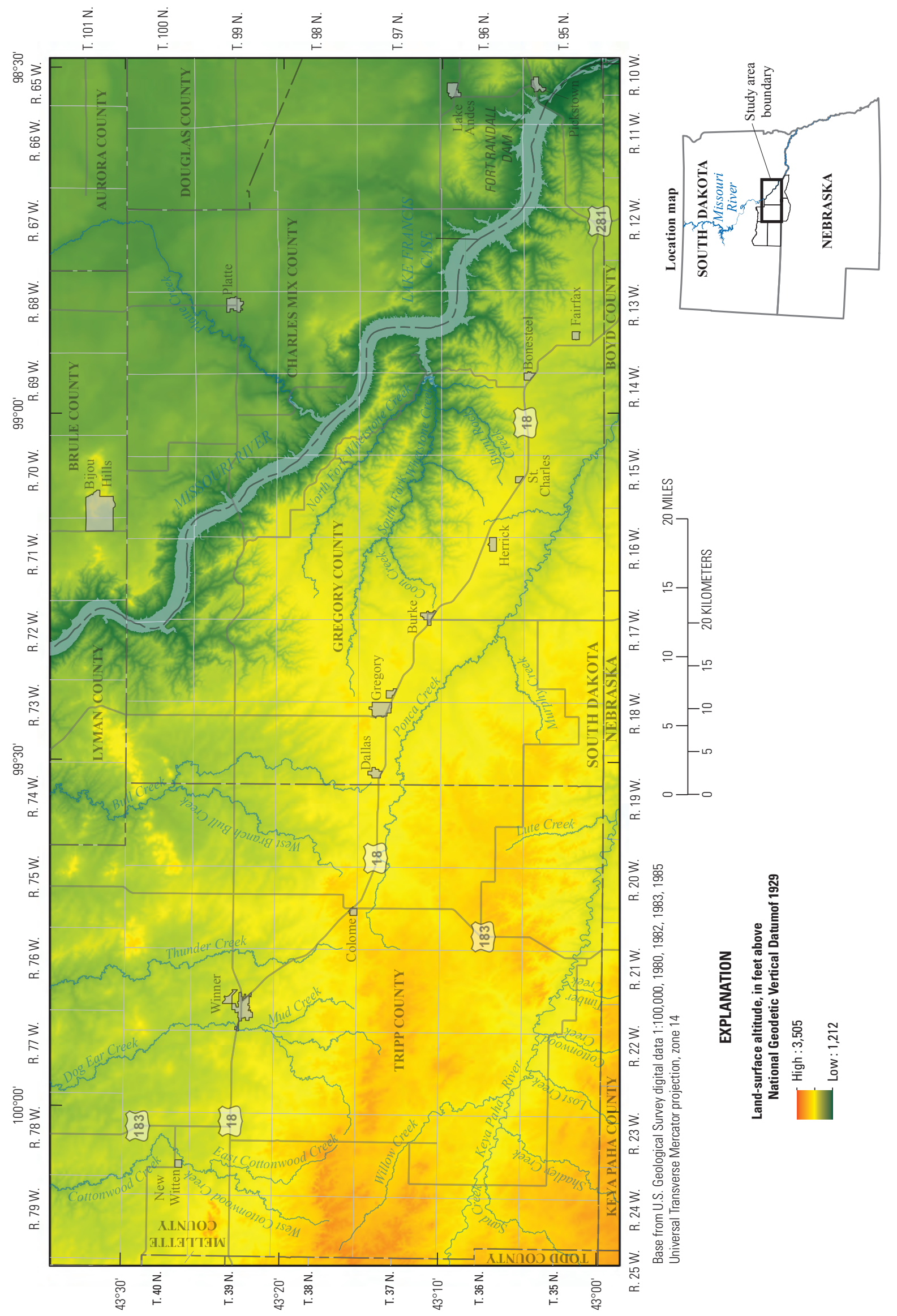

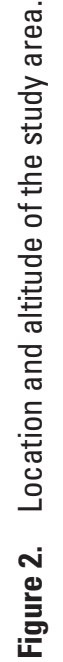


and Arikaree aquifers, in southern South Dakota and northern Nebraska. Kremin-Smith (1984) analyzed aquifer test data for the Ogallala aquifer in south-central Todd County. Carter (1998) described the water resources for Mellette and Todd Counties (located to the west of Tripp County; fig. 2), where the High Plains aquifer is used extensively for irrigation, public supply, domestic, and stock water supplies. Long and others (2003) and Long and Putnam (2010) performed threedimensional groundwater-flow modeling for the Ogallala and Arikaree aquifers in Mellette and Todd Counties. The model developed by Long and Putnam (2010) was an extension of the model developed by Long and others (2003) to address the effects of potential increased pumping and extended drought. Filipovic (2004) published a generalized water table and saturated thickness map and developed cross-sections for the Ogallala aquifer in Gregory and Tripp Counties based on lithologic, water-level, and geochemical data collected during 2003 and 2004. LaBelle (2011) estimated recharge to the Ogallala and Arikaree aquifers in Bennett, Jackson, and Shannon Counties in southwest-central South Dakota.

In 1978, the USGS initiated a study called the High Plains Regional Aquifer-System Analysis to evaluate the effects of groundwater development on the High Plains aquifer. The High Plains Regional Aquifer-System Analysis was completed as a part of the Regional Aquifer-System Analysis (RASA) Program, which was a response to a congressional mandate to quantitatively appraise the major groundwater systems of the United States (Weeks and others, 1988). Gutentag and others (1984) presented the geohydrology of the High Plains aquifer, including its depositional history in relation to bedrock, the quantity and quality of groundwater, and the history of groundwater development. Luckey and others (1986) described digital models used to simulate groundwater flow in the High Plains aquifer in the United States and subdivided the aquifer into the northern, central, and southern High Plains (fig. 1). Thelin and Heimes (1987) used satellite imagery to map irrigated land and estimated groundwater use on the basis of irrigated acreage. Luckey and others (1988) projected the effects of groundwater withdrawals on the High Plains aquifer for three potential scenarios. Weeks and others (1988) summarized the findings of the High Plains RASA study in detail.

\section{Description of Study Area}

The study area includes parts of Gregory and Tripp Counties and small parts of Mellette and Todd Counties in South Dakota as well as small parts of Boyd and Keya Paha Counties in Nebraska where the Ogallala aquifer is present. The study area is located within the Great Plains physiographic division (Fenneman, 1946) in the northern High Plains aquifer region (fig. 1; Luckey and others, 1988).

\section{Physiography, Land Use, and Climate}

Much of the study area has rolling topography and numerous deep valleys that drain to the southeast toward the Missouri River (figs. 2 and 3). The altitude of the study area ranges from more than $3,500 \mathrm{ft}$ above the National Geodetic Vertical Datum of 1929 (NGVD 29) near the western edge of the study area to slightly less than 1,200 ft above NGVD 29 in the southeastern part of the study area.

Agriculture is the primary land use within the study area. Approximately 55 percent of the land within the study area is used for cultivated crops, which include corn, alfalfa, grain sorghum, oats, and wheat (Springer, 1979; Wiesner, 1984). Approximately 42 percent of the land is range land used for grazing where native hay also is harvested. Land cover within Gregory and Tripp Counties includes herbaceous grassland, cultivated crops, hay and pasture, wetlands, forest, and lowdensity urban development (fig. 3; Multi-Resolution Land Characteristics Consortium, 2009). Most of land cover in the study area is herbaceous grassland.

The climate is continental, characterized by wide daily and annual ranges in temperature (Filipovic, 2004). The spring weather usually is rainy, cool, and windy; summer usually has moderate precipitation, hot days, and cool nights; the autumn months generally are mild; and the winter is characterized by low temperatures accompanied by wind and snow (Newport, 1959). The mean annual precipitation (1961-1990) is about 24 inches (in.) in Winner, S. Dak. (National Oceanic and Atmospheric Administration station 399367; High Plains Regional Climate Center, 2011).

\section{Drainage Features and Streamflow}

The major rivers that drain the study area are the Keya Paha River, the White River, the Ponca Creek, and the Missouri River (fig. 3). Smaller streams include several tributaries to the White and Missouri Rivers. Groundwater discharge from the Ogallala aquifer provides base flow to the Keya Paha River, which generally receives more than one-half of its flow from groundwater discharge, especially during the winter months (Carter, 1998). Direct runoff is the largest component of streamflow for streams that do not receive discharge from the Ogallala aquifer (Long and Putnam, 2010). The Missouri River flows through the eastern part of the study area and is impounded by the Fort Randall Dam, which forms Lake Francis Case within the Fort Randall Reservoir drainage basin (fig. 3).

\section{Geology}

Buried rocks in the study area include those of Precambrian age, the Ordovician-age Red River and Winnipeg Formations, and Cretaceous-age Dakota Sandstone. The exposed geologic formations within the study area consist of Cretaceous-, Tertiary-, and Quaternary-age rocks and 


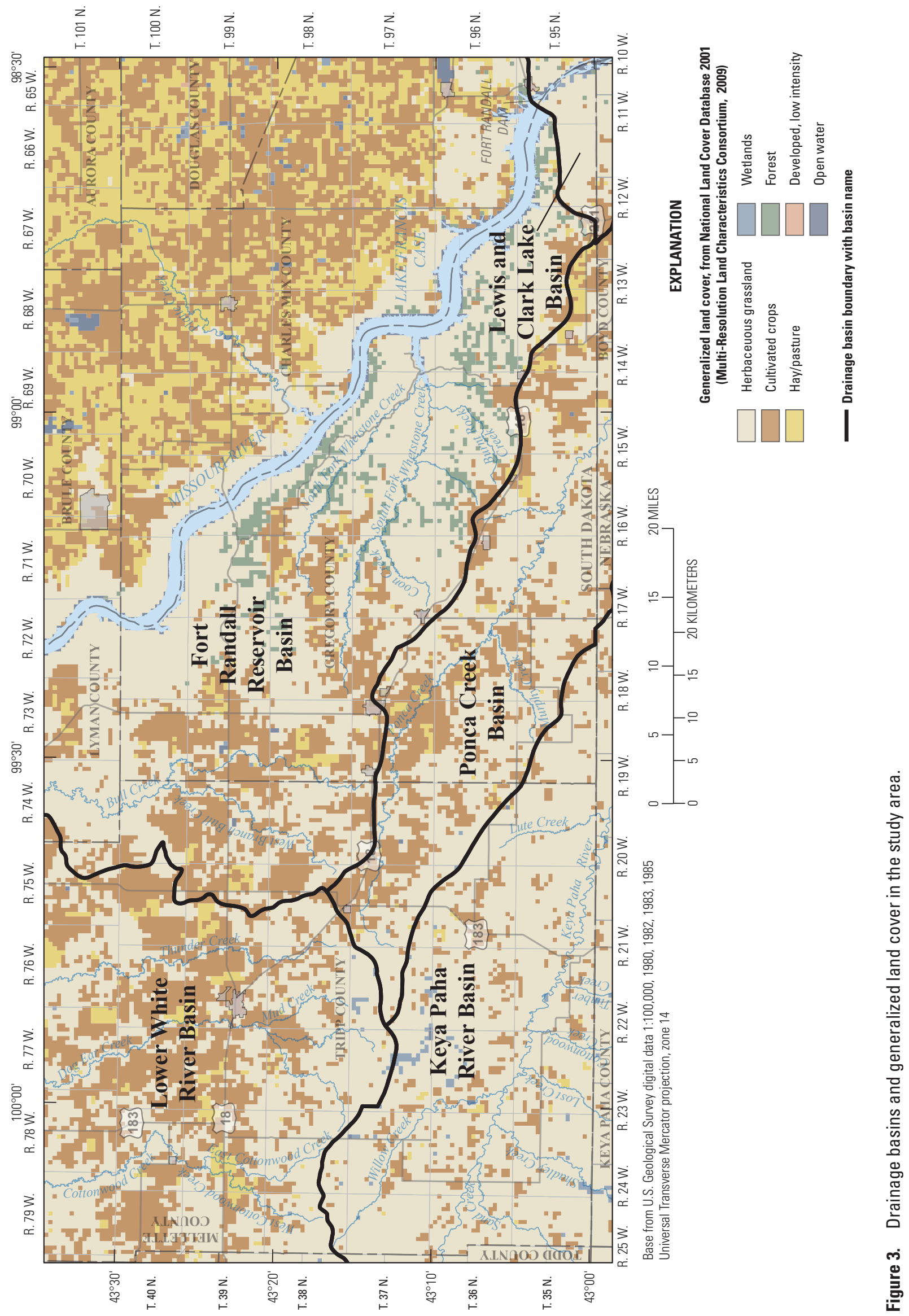


sediments (fig. 4; table 1). These exposed geologic formations are divided into the Cretaceous-age Niobrara Formation (small outcrop area in the southeastern corner of study area) and Pierre Shale; the Tertiary-age White River Group, Arikaree Formation, and Ogallala Formation; and Quaternaryage unconsolidated deposits. Unconsolidated deposits include glacial sediments east of the Missouri River and windblown, terrace, and alluvial sediments to the west of the Missouri River (fig. 4). Unconsolidated glacial sediments do not directly overlie the Ogallala Formation in the study area and therefore, glacial sediments are not included in table 1.

The Cretaceous-age Pierre Shale is a marine shale that is predominantly dark-gray and is present throughout the study area (Filipovic, 2004). The Oligocene-age White River Group is present to the west of the Missouri River near the western boundary of the study area (fig. 4) and was deposited unconformably on top of the Pierre Shale. The White River Group sometimes is divided into two units where distinguishablethe Chadron and Brule Formations (Filipovic, 2004). The Chadron Formation is the lower unit and is mainly composed of varicolored quartz sand and conglomerate interbedded with clay and silt deposited in channels. The overlying Brule Formation is a massive white, pink, light-green, and light-brown, bentonitic claystone and siltstone (Filipovic, 2004).

The Arikaree Formation is a moderately indurated, pinkcolored shale and siltstone. In the study area, the Arikaree Formation may be present only in the southwestern part (fig. 4), but the exact extent is not known because few wells penetrate this formation. The thickness of the Arikaree Formation varies with the undulating unconformity between it and the overlying Ogallala Formation (Rahn and Paul, 1975). The lower 50 to $150 \mathrm{ft}$ is characterized by silty and sandy beds that commonly are separated from the upper clayey part by 5 to $10 \mathrm{ft}$ of thinbedded limestone (Long and Putnam, 2010).

The extent of the Ogallala Formation in the study area is indicated by the extent of the northern High Plains aquifer in figure 1; thus, it is not present to the east of the Missouri River. The Ogallala Formation directly overlies parts of the Arikaree Formation, the White River Group, and the Pierre Shale within the study area. Early South Dakota Geological Survey quadrangle maps (Stevenson and Buckmeier, 1958; Sevon and Petsch, 1960) divided the Ogallala Formation into two units - the underlying Valentine Formation and the overlying Ash Hollow Formation. More recently, Ellis and others (1971) and Harksen and McDonald (1969) have called the Ogallala Formation one unit because of the indistinct field identification of the two units (Rahn and Paul, 1975). The Ogallala Formation consists of an olive-colored, mediumgrained pure quartz sandstone that is poorly indurated (Rahn and Paul, 1975). The formation consists of interbedded layers of sandy gravel, sand, silt, and clay. Some lenses of volcanic ash also are present (Newport, 1959).

The Ogallala Formation was deposited unconformably on the uneven surface of the Pierre Shale, White River Group, or Arikaree Formation where present in the study area. The Ogallala Formation was deeply eroded by streams in the
Quaternary period; therefore, it differs considerably in thickness from place to place (Newport, 1959). The thickness of the Ogallala Formation ranges from 0 to $200 \mathrm{ft}$ in the study area and is controlled primarily by the morphology of the eroded pre-Ogallala surface (Filipovic, 2004). The altitude of the base of the Ogallala Formation in Gregory and Tripp Counties was estimated from lithologic logs and ranged from 1,621 to $2,445 \mathrm{ft}$ above NGVD 29. The basal dip of the Ogallala aquifer is about 10 feet per mile $(\mathrm{ft} / \mathrm{mi})$ to the southeast.

Sediments of Quaternary age consist of glacial, terrace, windblown, and alluvial deposits. The windblown deposits consist of sand that is sometimes calcareous and is derived from the Ogallala Formation. In some places, the contact between the windblown deposits and the Ogallala Formation is not easily identified. Alluvium is present in fluvial floodplains and terrace sediments along active streams and rivers (Filipovic, 2004). Glacial sediments were deposited to the east of the Missouri River.

\section{Hydrogeology}

The Dakota Sandstone, the Ogallala Formation, and deposits of sandy gravel of Quaternary age are the principal water-bearing rocks in the study area (Newport, 1959). The shallow aquifers in the study area are the alluvial, Ogallala, Arikaree, and White River aquifers. These shallow aquifers consist primarily of unconsolidated sand and gravel or poorly consolidated sandstones and siltstones (Long and Putnam, 2010). Well logs indicate that the deep bedrock aquifers are the Pierre and Dakota aquifers (South Dakota Department of Environment and Natural Resources, 2011).

The Ogallala aquifer is composed of the saturated sandstones, gravel, sand, and silt of the Ogallala Formation. The upper unit of the Ogallala Formation has relatively low permeability, but small seeps occur near its base (Ellis and others, 1971). The lower unit of the Ogallala Formation generally is water bearing; however, the permeability of that unit varies with lithology. Where the Ogallala Formation caps narrow ridges or is near deeply entrenched streams, discharge generally is greater than recharge, and the Ogallala aquifer will not yield large amounts of water to wells (Newport, 1959). Where the Ogallala Formation is thick and at least a few miles distant from deeply entrenched streams, it contains a large quantity of water (Newport, 1959). The base of the Ogallala aquifer is coincident with the base of the Ogallala Formation. Unconsolidated Quaternary-age windblown, terrace, and alluvial deposits overlying the Ogallala Formation to the west of the Missouri River are considered part of the Ogallala aquifer because these deposits are assumed to be in hydraulic connection with the Ogallala aquifer (Weeks and Gutentag, 1981).

The Ogallala aquifer is considered unconfined within the study area even though it is overlain by younger deposits in some areas. In the study area, the depth to water ranges from about 5 to $132 \mathrm{ft}$ below the land surface, and the saturated thickness ranges from about 0 to $190 \mathrm{ft}$ (Filipovic, 2004). The 

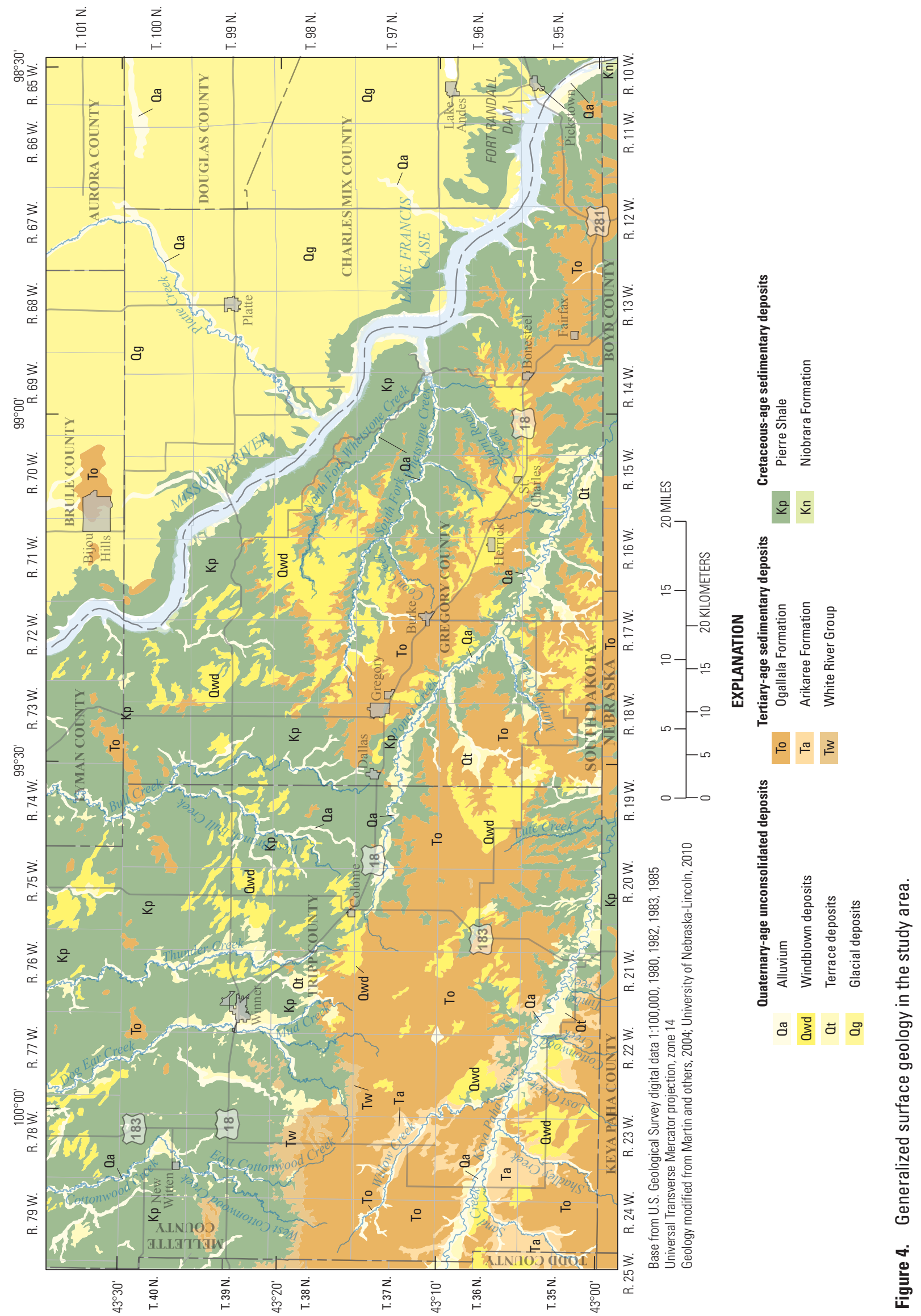
Table 1. Generalized stratigraphic column showing geologic units west of the Missouri River in study area.

[Modified from Carter (1998), Diffendal and Voorhies (1994), and Newport (1959). --, not applicable]

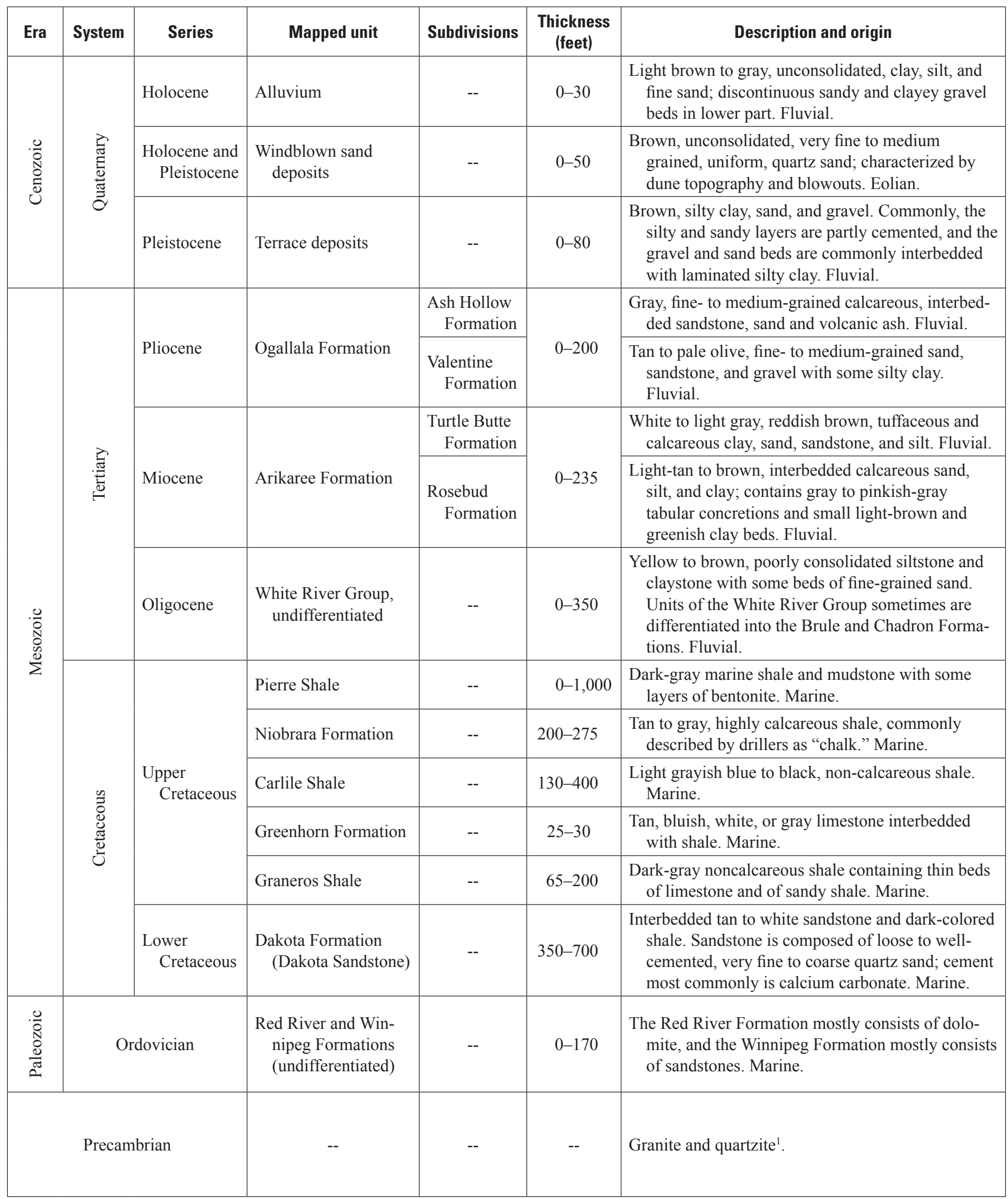

${ }^{1}$ From McCormick (2010). 
Ogallala aquifer is present throughout most of the southern part of the study area where it underlies approximately $1,050 \mathrm{mi}^{2}$ in Gregory and Tripp Counties and is absent in the northern part of the study area where older formations are exposed at land surface and to the east of the Missouri River (fig. 4).

Drainages of the large streams in the study area have cut down through the base of the aquifer and have exposed the underlying rock units. Within the study area, both the Keya Paha River and Ponca Creek are eroded through the base of the aquifer. The alluvial sediments surrounding the Keya Paha River are in contact with the Ogallala aquifer and thus are considered hydraulically connected to the aquifer (fig. 4). Alluvial sediments surrounding Ponca Creek are separated from the Ogallala aquifer by the low permeability Pierre Shale, and therefore are not hydraulically connected to the Ogallala aquifer. In the study area, the Ogallala aquifer is generally thickest in the central part of Tripp County (Filipovic, 2004).

The Arikaree aquifer generally comprises the saturated sandstones and siltstones of the Arikaree Formation and generally is confined where overlain by low permeability materials at the base of the Ogallala Formation (Long and others, 2003). Although the Arikaree aquifer contains saturated material, it will not readily yield water for withdrawal, unless highly fractured or fissured, because of its low permeability (Rahn and Paul, 1975). For this study, the Arikaree Formation, where present, is considered to represent the impermeable lower boundary of the overlying Ogallala aquifer because of its low permeability. Additionally, few wells within the study area penetrate the Arikaree aquifer. The Arikaree aquifer is present in the southwestern part of the study area where it underlies the Ogallala aquifer. The Ogallala and Arikaree aquifers collectively compose the High Plains aquifer system, which extends southward for hundreds of miles.

Where directly underlying the Ogallala Formation, the Brule Formation of the White River Group serves as the lower impermeable boundary for the Ogallala aquifer. The White River Group exists in the western part of the study area. Where the White River Group and Arikaree Formation are not present, the Pierre Shale serves as the impermeable lower boundary for the Ogallala aquifer (Newport, 1959).

\section{Conceptual Model}

A conceptual model of the Ogallala aquifer was used to analyze groundwater flow in the study area and to develop input datasets for a numerical model to simulate groundwater flow in the aquifer. The conceptual model describes the hydrogeologic framework, groundwater flow, hydraulic properties, and water budget components of the Ogallala aquifer for WYs 1985-2009.

\section{Hydrogeologic Framework}

The unconsolidated Quaternary-age windblown, terrace, and alluvial deposits overlying the Ogallala aquifer within the study area have similar hydrogeologic properties and are in direct hydraulic connection with the Ogallala aquifer (Weeks and Gutentag, 1981); therefore, these units are considered together with the Ogallala aquifer as a single, water-bearing unit for the purposes of this study. The Pierre Shale, White River Group, and Arikaree Formation are considered the underlying confining units for the Ogallala aquifer where they directly underlie the Ogallala Formation because of their low permeability.

Recharge to the Ogallala aquifer occurs from precipitation on the outcrop of the Ogallala Formation. Groundwater originating from precipitation moves from areas of high altitude toward streams that gain flow from the Ogallala aquifer. Discharge by evapotranspiration from the aquifer occurs in areas where the water table is at or near the land surface. Additionally, discharge from the Ogallala aquifer occurs through withdrawals for irrigation, production, domestic, and stock wells (Filipovic, 2004).

The saturated thickness of the aquifer was determined by examining well completion reports (South Dakota Department of Environment and Natural Resources, 2011) and saturated thickness contours published by Filipovic (2004). The saturated thickness at individual well locations and saturated thickness contours were used to interpolate the saturated thickness of the Ogallala aquifer in the study area. A geographic information system (GIS) layer of the distribution of the saturated thickness in the study area was developed using the kriging interpolation from the Geostatistical Analyst tool in ArcGIS (Esri, 2011a,b). The mean saturated thickness for the Ogallala aquifer ranged from 10 to $166 \mathrm{ft}$ (fig. 5).

\section{Groundwater Flow}

A mean potentiometric surface was estimated for the analysis period (WYs 1985-2009) for the Ogallala aquifer. The extents of the Ogallala aquifer were modified from Martin and others (2004) and Filipovic (2004) to represent areas with sufficient saturation for inclusion in the numerical model (figs. 6 and 7). The mean potentiometric surface was constructed from water-level data and associated land-surface altitudes from 261 wells between October 1, 1984, and September 30, 2009 (WYs 1985-2009).

Water levels during 2002 and 2003 were documented by Filipovic (2004) for selected wells completed in the Ogallala aquifer. Filipovic (2004) drilled 126 test holes, 21 of which were completed as observation wells in the Ogallala aquifer (fig. 6). Filipovic (2004) concluded that water-level altitudes in wells completed in the Ogallala aquifer ranged from 1,898 to 2,476 ft above NGVD 29. From 1978 through 2003, selected wells showed water-level fluctuations of less than $10 \mathrm{ft}$ (Filipovic, 2004). Estimated water levels from test holes 

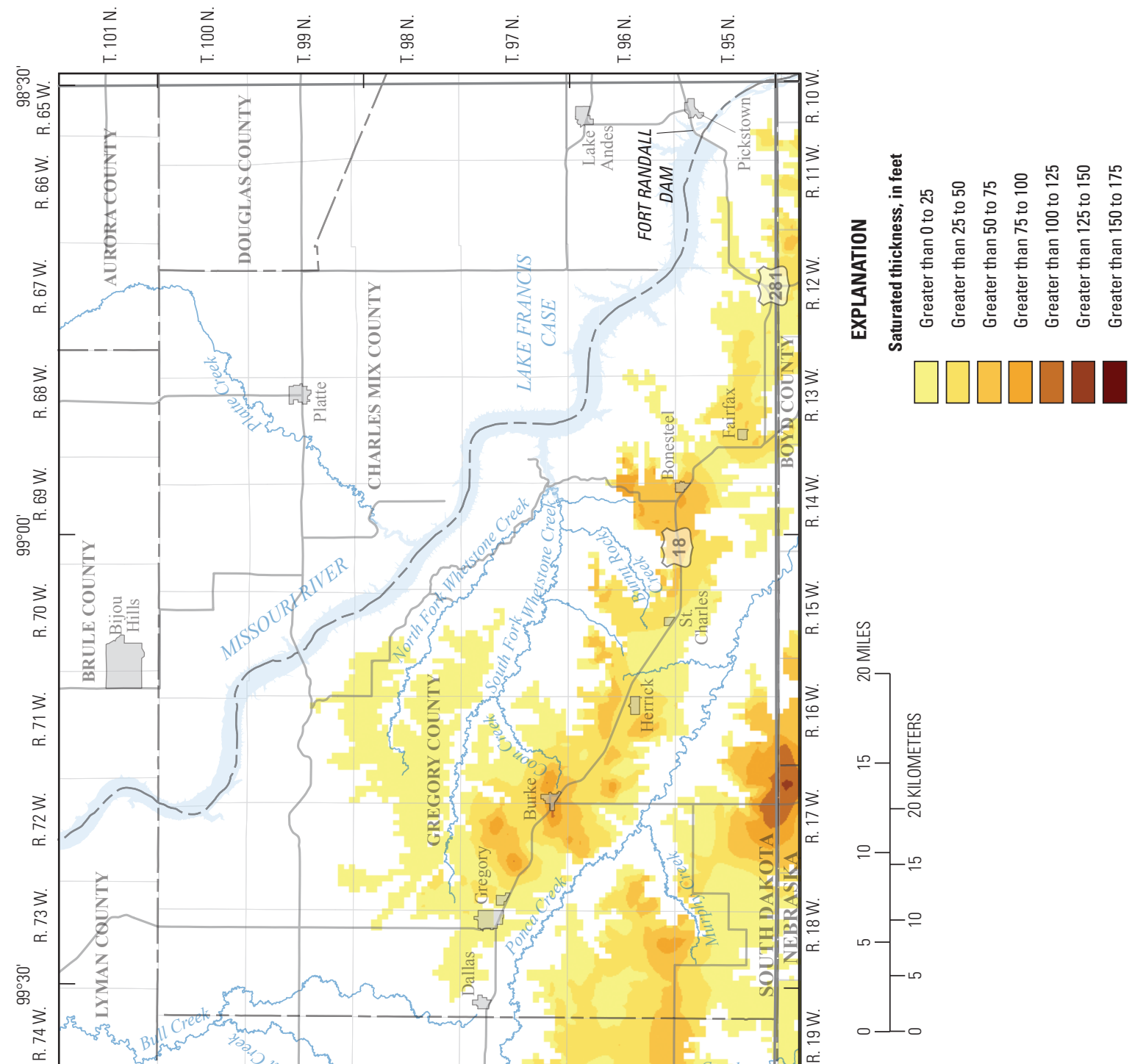

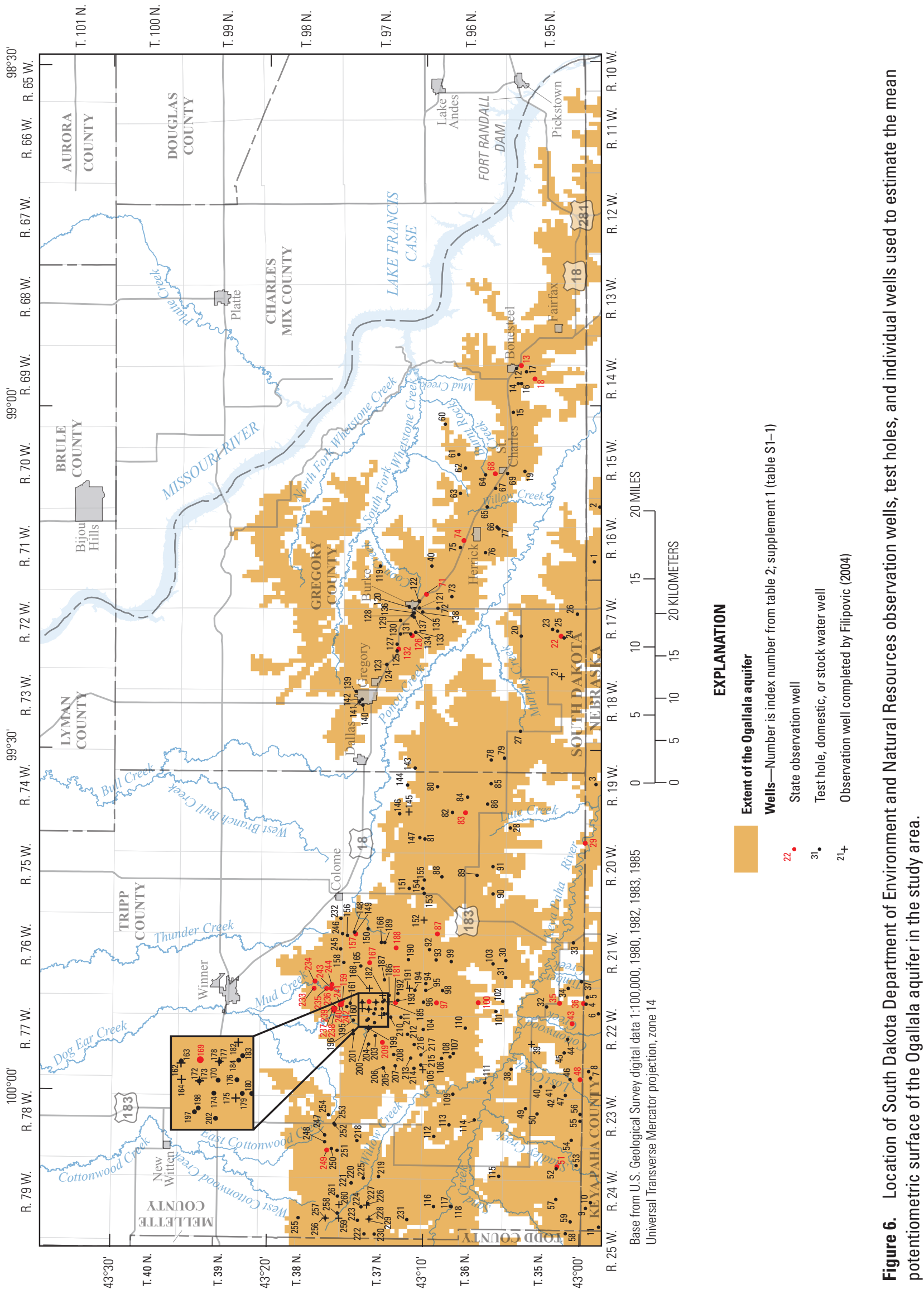

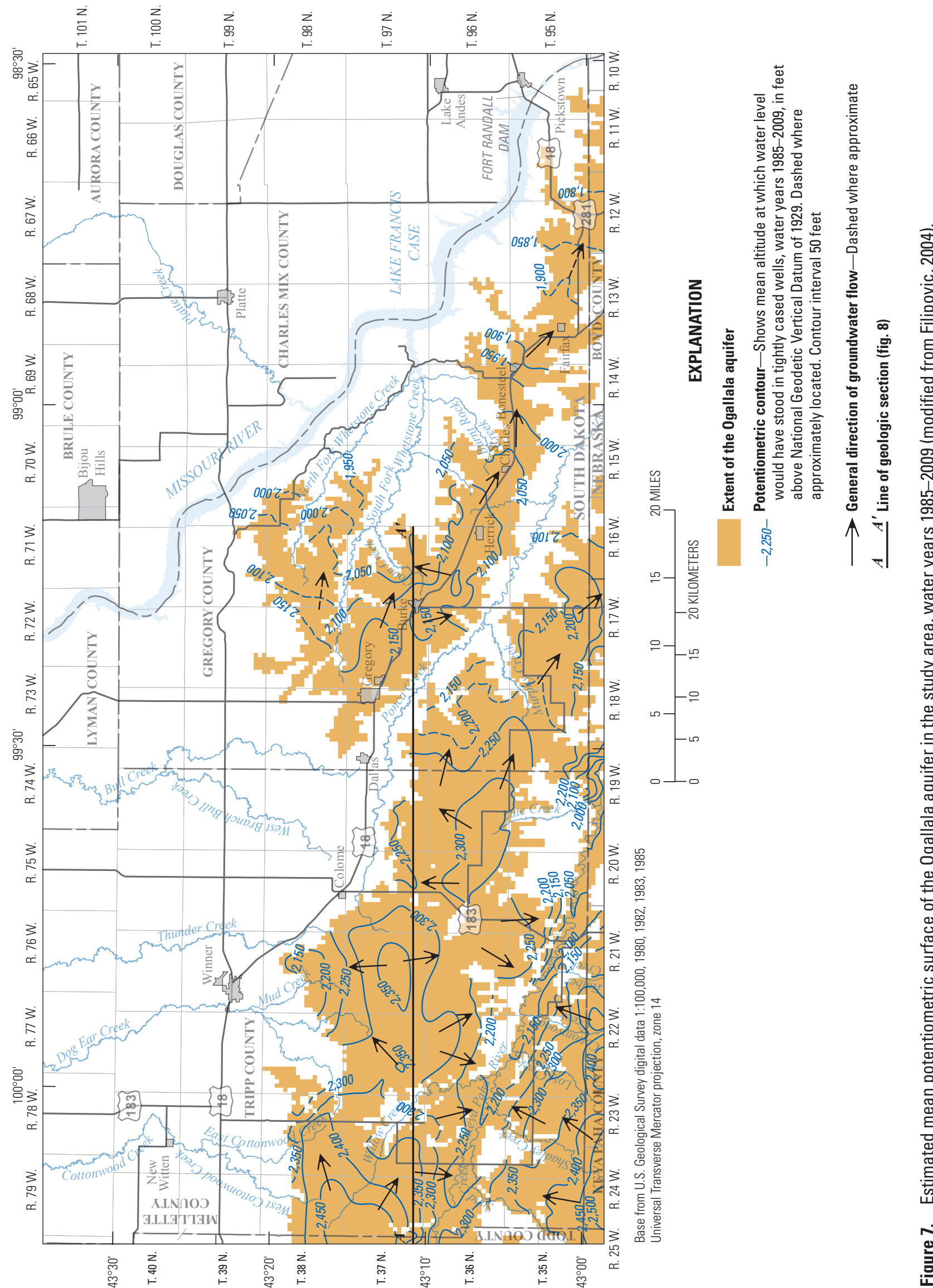
and measured water levels in observation wells completed by Filipovic (2004) were used to estimate the mean potentiometric surface for the study area for WYs 1985-2009 (table S1-1).

Long-term records were available for 38 State observation wells completed in the Ogallala aquifer in the study area that are maintained by the South Dakota Department of Environment and Natural Resources (SDDENR; fig. 6; table 2; Ken Buhler, South Dakota Environment and Natural Resources, written commun., 2009). During the 25 -year analysis period, some water levels increased, some decreased, and some changed very little.

Additional water-level data were obtained from the USGS National Water Information System database (U.S. Geological Survey, 2011), well completion reports (Ken Buhler, South Dakota Environment and Natural Resources, written commun., 2009), and lithologic logs (South Dakota Department of Environment and Natural Resources, 2010) for 223 well and test hole locations (fig. 6; table S1-1). These additional data represent SDDENR test holes and domestic and stock wells located within the study area. Data used for the construction of the mean potentiometric surface included well locations, land-surface altitude, and depth to water. In many cases, the land-surface altitude of a well location was not provided. Any well that did not have land-surface altitude information was plotted at its legal location using the GIS software ArcMap (Esri, 2011c), and the National Elevation Dataset (NED; U.S. Geological Survey, 2006) for the study area was used to determine the land-surface altitude at each well.

Using the land-surface altitude for each well and the depth to water, the mean water-level altitude (hydraulic head) for each well was determined (table S1-1). Wells with a single water-level measurement were used without adjustment. All water-level measurements for individual State observation wells were averaged for the 25 -year analysis period. In locations where few water-level data were available, the potentiometric surface published by Filipovic (2004) was used as control. The kriging interpolation from the Geostatistical Analyst tool was used to interpolate the mean potentiometric surface in the study area. Kriging assumes that the distance or direction between sample points (hydraulic-head measurements) reflects a spatial correlation that can be used to explain the variation in a surface (potentiometric surface). The kriging interpolation from the Geostatistical Analyst tool fit a mathematical function to a specified number of points or all points within a specified radius of measurement locations to determine the output value for each location. Kriging weights surrounding measured values were used to derive a prediction for an unmeasured location (Esri, 2011b). The Geostatistical Analyst tool and the kriging algorithm are described in the help documentation for ArcGIS (Esri, 2011a,b).

In some low-lying parts of the study area, the interpolated potentiometric surface was above the land surface. Where above the land surface, the interpolated hydraulic head was set equal to the land-surface altitude. The resulting potentiometric surface map represents mean conditions for the 25-year analysis period. Water-level data for the Ogallala aquifer were not available southeast of Fairfax, S. Dak., in the study area (fig. 7). Therefore, the potentiometric surface was extrapolated southeast of Fairfax to include all parts of the Ogallala aquifer within the study area.

The mean potentiometric surface for WYs 1985-2009 (fig. 7) indicates that the hydraulic head of the Ogallala aquifer ranged from less than 1,800 to greater than $2,500 \mathrm{ft}$, and the hydraulic gradient was about $6 \mathrm{ft} / \mathrm{mi}$ toward the southeast. Locally, groundwater flow is topographically controlled and is toward perennial streams and rivers (figs. 7 and 8). On the basis of the orientation of the potentiometric surface, regional inflow occurs along the western and southwestern boundaries of the study area, and regional outflow occurs along the southeastern boundary of the study area. Because of the low permeability units at the base of the Ogallala aquifer, upward and downward seepage of groundwater were assumed to be negligible. Thus, groundwater flow in the Ogallala aquifer is assumed to be predominantly horizontal.

ArcGIS layers for the mean saturated thickness (fig. 5) and the mean potentiometric surface (fig. 7) were used to determine the base of the Ogallala aquifer in the study area. The mean saturated thickness was subtracted from the mean potentiometric surface to calculate the aquifer base (fig. 9). The altitude of the base of the aquifer ranged from 1,621 ft above NGVD 29 in the southeast part of the study area to $2,445 \mathrm{ft}$ above NGVD 29 in the western part of the study area.

\section{Hydraulic Properties}

Hydraulic properties (transmissivity, hydraulic conductivity, storage coefficient, and specific yield) for the Ogallala aquifer in and near the study area have been estimated by previous investigators (table 3). Rahn and Paul (1975) estimated hydraulic properties for the Ogallala aquifer by conducting an aquifer test in southwestern Todd County and analyzing time- and distance-drawdown data for water levels measured in 11 observation wells. The mean hydraulic conductivity determined from the aquifer test, assuming a mean saturated thickness of $84 \mathrm{ft}$, was 58.7 feet per day (ft/d). The hydraulic conductivity ranged from 28.8 to $189.4 \mathrm{ft} / \mathrm{d}$. This represents a mean transmissivity of 4,930 square feet per day $\left(\mathrm{ft}^{2} / \mathrm{d}\right)$. Specific yields ranged from 0.00921 to 0.23 (Rahn and Paul, 1975). Kolm and Case (1983) estimated hydraulic conductivity for the High Plains aquifer in South Dakota by analyzing grain-size descriptions from 205 wells logs. The estimated hydraulic conductivity ranged from 3.6 to $160 \mathrm{ft} / \mathrm{d}$ (Kolm and Case, 1983). Kremin-Smith (1984) analyzed data from three aquifer tests. The hydraulic conductivity ranged from 7.9 to $21.6 \mathrm{ft} / \mathrm{d}$, and transmissivity ranged from 1,644 to $3,088 \mathrm{ft}^{2} / \mathrm{d}$ for the three aquifer tests.

Long and others (2003) and Long and Putnam (2010) simulated groundwater flow in the Ogallala and Arikaree aquifers in Mellette and Todd Counties in south-central South 
Table 2. Selected data for long-term State observation wells completed in the Ogallala aquifer in Gregory and Tripp Counties.

[Hydraulic heads are estimated means for water years 1985-2009. NGVD 29, National Geodetic Vertical Datum of 1929; --, no data]

\begin{tabular}{|c|c|c|c|c|c|c|}
\hline $\begin{array}{l}\text { Index number } \\
\text { (fig. 6) }\end{array}$ & Well name & $\begin{array}{c}\text { Site identification } \\
\text { number }\end{array}$ & Legal location & $\begin{array}{l}\text { Land-surface altitude } \\
\text { (feet above NGVD 29) }\end{array}$ & Well depth & $\begin{array}{c}\text { Mean measured } \\
\text { hydraulic head } \\
\text { (feet above NGVD 29) }\end{array}$ \\
\hline 74 & GY-57A & 430743099115001 & 96N71W13CCBB & 2,163 & 39 & $2,138.5$ \\
\hline 68 & GY-57B & 430542099055901 & 96N70W34AAAD & 2,085 & 16 & $2,080.0$ \\
\hline 126 & GY-77A & 431153099212201 & 97N72W21DDDD & 2,150 & 53 & $2,145.2$ \\
\hline 132 & GY-77B & 431101099211901 & 97N72W27DDDD & 2,163 & 56 & $2,152.9$ \\
\hline 22 & GY-78B & 430129099201201 & 95N72W22DDDD & 2,217 & 104 & $2,182.7$ \\
\hline 13 & GY-78C & 430405098563401 & 95N69W 1DDDD & 1,930 & 64 & $1,897.7$ \\
\hline 18 & GY-78D & 430310098574401 & 95N69W14AAAA & 1,943 & 83 & $1,909.7$ \\
\hline 29 & $\mathrm{TR}-57 \mathrm{C}$ & 425946099382001 & 95N74W31DDCC 1 & 1,990 & 30 & $1,963.1$ \\
\hline 234 & TR-72B & 431703099502901 & 98N76W28BAAA & 2,198 & 84 & $2,171.8$ \\
\hline 235 & $\mathrm{TR}-72 \mathrm{C}$ & 431714099510501 & 98N76W29DDAA & 2,231 & 57 & $2,216.4$ \\
\hline 243 & $\mathrm{TR}-72 \mathrm{D}$ & 431604099510401 & 98N76W32AADD & 2,241 & 63 & $2,221.8$ \\
\hline 159 & $\mathrm{TR}-72 \mathrm{E}$ & 431519099520301 & 97N76W 5BBBA & 2,264 & 42 & $2,257.3$ \\
\hline 237 & $\mathrm{TR}-72 \mathrm{~F}$ & 431553099525701 & 98N76W31BDCA & 2,282 & 118 & $2,238.3$ \\
\hline 238 & $\mathrm{TR}-72 \mathrm{G}$ & 431553099524602 & 98N76W31BDDB 2 & 2,265 & -- & $2,231.2$ \\
\hline 239 & $\mathrm{TR}-72 \mathrm{H}$ & 431553099525503 & 98N76W31BDDB 3 & 2,265 & -- & $2,225.3$ \\
\hline 236 & $\mathrm{TR}-74 \mathrm{~A}$ & 431550099524501 & 98N76W31ACCC & 2,260 & 28 & $2,248.8$ \\
\hline 209 & $\mathrm{TR}-78 \mathrm{C}$ & 431243099553601 & 97N77W23BBBB & 2,340 & 105 & $2,335.7$ \\
\hline 249 & $\mathrm{TR}-78 \mathrm{D}$ & 431608100051101 & 98N78W33BBBB & 2,430 & 78 & $2,416.7$ \\
\hline 51 & $\mathrm{TR}-78 \mathrm{E}$ & 430133100061501 & 95N78W20CCCC & 2,430 & 105 & $2,388.3$ \\
\hline 35 & $\mathrm{TR}-78 \mathrm{~F}$ & 430128099520001 & 95N76W29BBBB & 2,253 & 77 & $2,222.4$ \\
\hline 157 & $\mathrm{TR}-78 \mathrm{G}$ & 431434099462401 & 97N76W 1DDDD & 2,341 & 45 & $2,323.3$ \\
\hline 167 & $\mathrm{TR}-78 \mathrm{H}$ & 431330099484501 & 97N76W15AABA & 2,332 & 85 & $2,327.4$ \\
\hline 188 & TR-78I & 431156099472601 & 97N76W23DDDD & 2,362 & 65 & $2,355.8$ \\
\hline 97 & TR-78J & 430919099521501 & 96N76W 6DDDD & 2,309 & 25 & $2,305.5$ \\
\hline 87 & $\mathrm{TR}-78 \mathrm{~K}$ & 430923099461001 & 96N75W 6CCCC & 2,301 & 30 & $2,290.3$ \\
\hline 100 & TR-78L & 430638099520801 & 96N76W29BBBB & 2,246 & 46 & $2,235.7$ \\
\hline 43 & TR-78M & 430037099535601 & 95N77W25DCCC & 2,288 & 185 & $2,244.9$ \\
\hline 36 & $\mathrm{TR}-78 \mathrm{~N}$ & 425956099520501 & 95N76W32CCCC & 2,348 & 66 & $2,337.8$ \\
\hline 83 & TR-79A & 430732099353201 & 96N74W16DDDD & 2,342 & 35 & $2,334.8$ \\
\hline
\end{tabular}




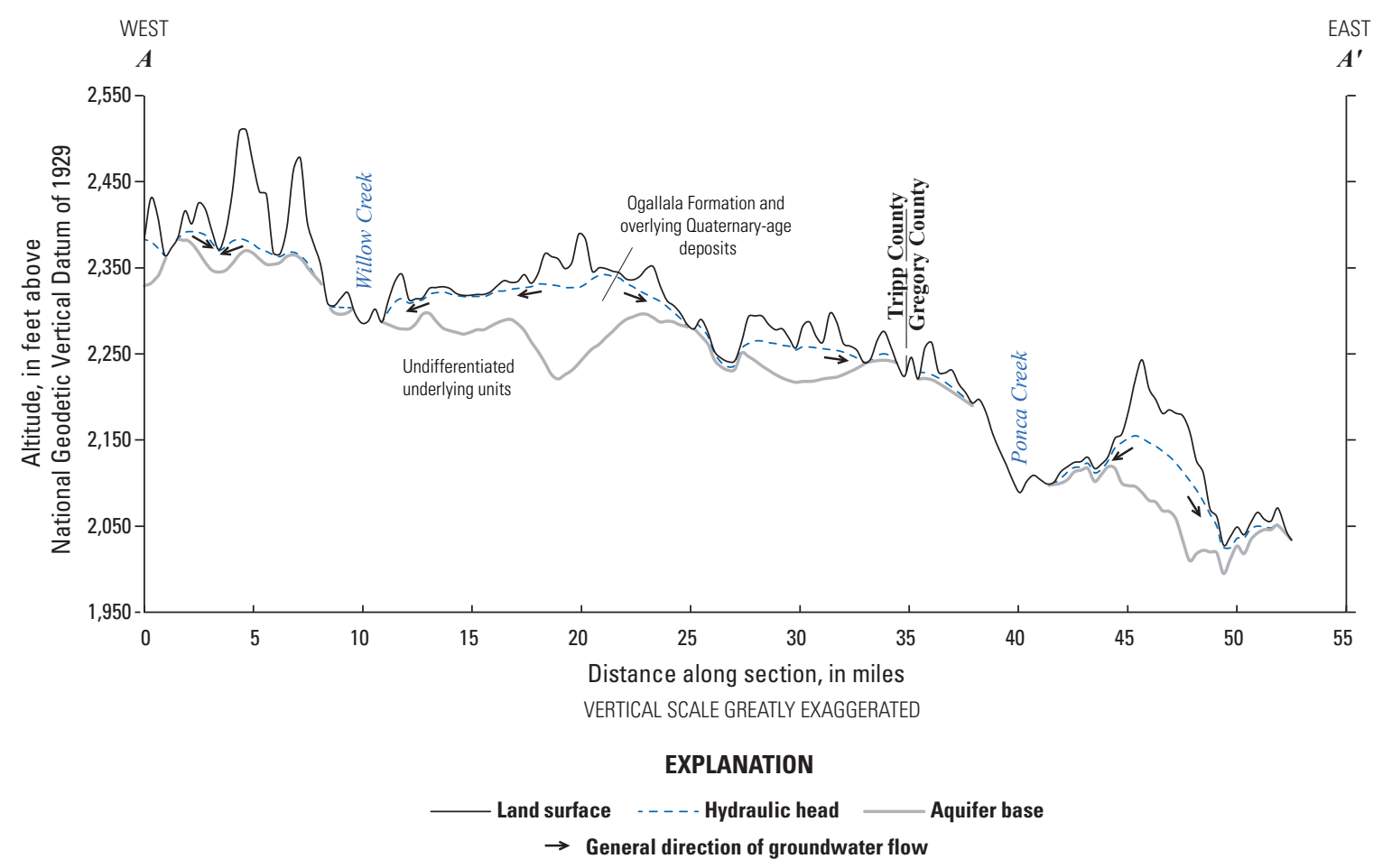

Figure 8. Generalized relationship between hydraulic head, hydrogeologic units, and topographic features for cross-section $A-A^{\prime}$. Location of section shown in figure 7.

Dakota. Long and others (2003) estimated that hydraulic conductivity ranged from 0.2 to $120 \mathrm{ft} / \mathrm{d}$ based on previously published values and the spatial distribution of specific capacities of wells. Long and Putnam (2010) published an extension of the model by Long and others (2003) and used inverse modeling techniques to estimate the hydraulic conductivity for the Ogallala aquifer. Estimated hydraulic conductivity ranged from 0.2 to $84.4 \mathrm{ft} / \mathrm{d}$ (Long and Putnam, 2010).

Hammond and others (1996) conducted an aquifer test in the southeastern part of the study area near Bonesteel, S. Dak. Analysis of aquifer test data indicated an estimated hydraulic conductivity of $86.7 \mathrm{ft} / \mathrm{d}$ and a storage coefficient of 0.00045 . Hammond and others (1996) concluded that the aquifer was under semiconfined conditions and suggested that the silt and clay layers in the aquifer act as confining or semiconfining layers in the aquifer near Bonesteel.

Specific capacity was calculated using data for 88 wells completed in the Ogallala aquifer in the study area (fig. 10; table S2-1). Specific capacity of the 88 wells ranged from 0.03 to 24 gallons per minute per foot [(gal/min)/ft] of drawdown, with a mean of $2.54(\mathrm{gal} / \mathrm{min}) / \mathrm{ft}$. Transmissivity for the same wells was calculated with methods documented by Mace (2001). Based on the well discharge rate, measured drawdown, pumping time, well radius, and storage coefficient, the calculated transmissivity at these 88 wells ranged from 2.59 to about 4,950 $\mathrm{ft}^{2} / \mathrm{d}$ (table S2-1).

The calculated transmissivity data were compiled in a GIS layer. Using the kriging interpolation from the
Geostatistical Analyst tool, the transmissivity for the study area was plotted in a GIS layer representing the spatial distribution of transmissivity. The spatial distribution of hydraulic conductivity (fig. 10) for the study area was calculated by dividing the GIS layer for the estimated transmissivity distribution by the GIS layer for the estimated mean saturated thickness distribution (fig. 5) in ArcMap.

\section{Water Budget Components}

Water budget components of recharge and discharge are described in this section. Recharge occurs by infiltration of precipitation. Discharge occurs through evapotranspiration, discharge to streams, and well withdrawals.

In order to more clearly describe water budget components, each water year during the 25-year analysis period (WYs 1985-2009) was subdivided into three discrete time intervals called stress periods. For each year of the analysis, stress periods represent (1) fall/winter (October through February), (2) spring (March through May), and (3) summer (June through September). Three stress periods per year were determined to adequately represent seasonal changes in hydrologic data. Stress periods were numbered from 1 through 75, with stress period 1 representing October 1984 through February 1985, and stress period 75 representing June 2009 through September 2009. 


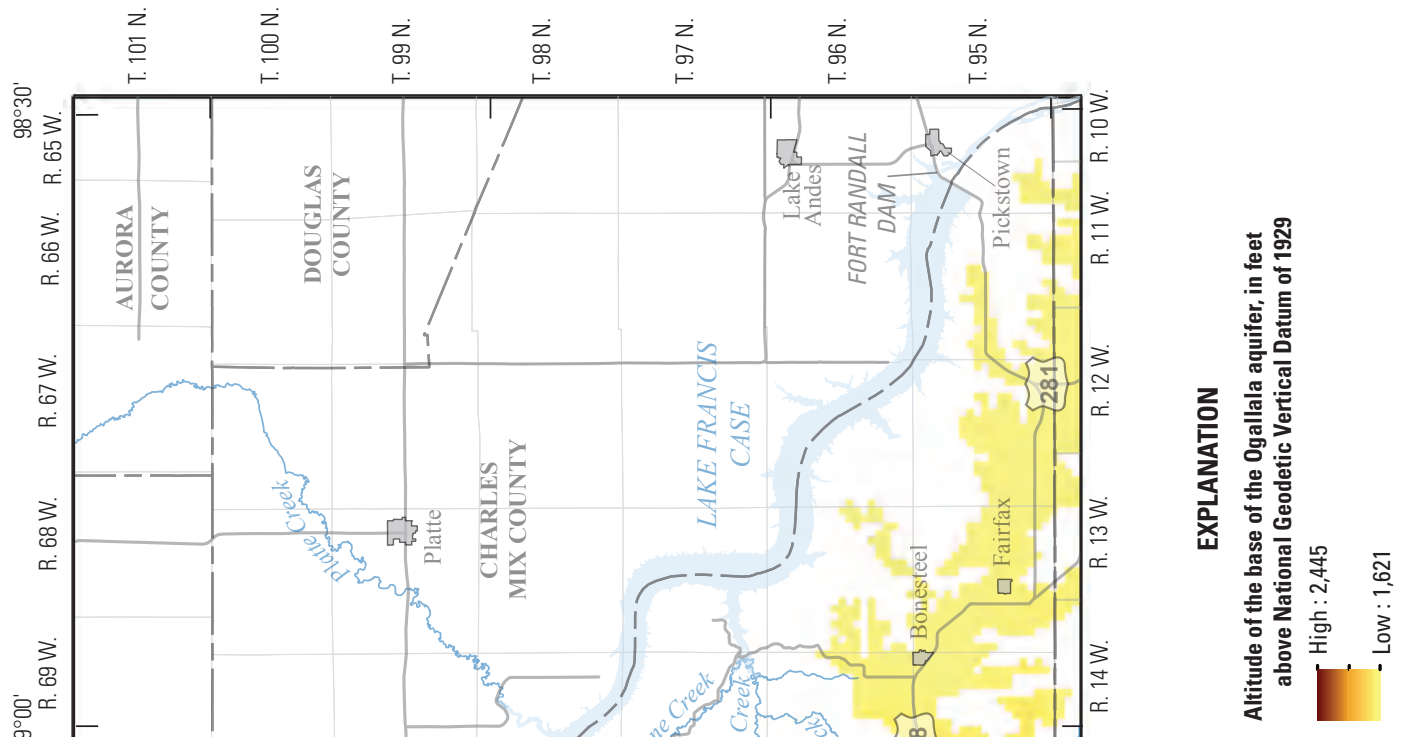

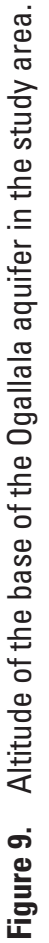


Table 3. Previously published hydraulic properties within or near the study area.

$\left[\mathrm{ft}^{2} / \mathrm{d}\right.$, feet squared per day; $\mathrm{ft} / \mathrm{d}$, feet per day; --, no data]

\begin{tabular}{|c|c|c|c|c|c|c|c|}
\hline Method & $\begin{array}{l}\text { In } \\
\text { study } \\
\text { area }\end{array}$ & $\begin{array}{l}\text { Transmis- } \\
\text { sivity } \\
\left(\mathrm{ft}^{2} / \mathrm{d}\right)\end{array}$ & $\begin{array}{c}\text { Hydraulic } \\
\text { conductivity } \\
\text { (ft/d) }\end{array}$ & $\begin{array}{l}\text { Storage } \\
\text { coefficient } \\
\text { (dimen- } \\
\text { sionless) }\end{array}$ & $\begin{array}{l}\text { Specific yield } \\
\text { (dimension- } \\
\text { less) }\end{array}$ & Location & Source \\
\hline \multicolumn{8}{|c|}{ Ogallala aquifer } \\
\hline $\begin{array}{l}\text { Time drawdown } \\
\text { aquifer test }\end{array}$ & Yes & 5,027 & $86.7^{\mathrm{a}}$ & 0.00045 & -- & $\begin{array}{l}\text { 95N69W12 (near Bonesteel, } \\
\text { S. Dak.) }\end{array}$ & $\begin{array}{r}\text { Hammond and } \\
\text { others, } 1996\end{array}$ \\
\hline $\begin{array}{l}\text { Time drawdown } \\
\text { and distance } \\
\text { drawdown } \\
\text { aquifer tests }\end{array}$ & No & 4,930 & $\begin{array}{l}28.8-189.4 ; \\
\quad \text { mean } 58.7^{\mathrm{b}}\end{array}$ & $\begin{array}{c}0.0026- \\
0.055\end{array}$ & $\begin{array}{r}0.00921-0.23 \\
\text { mean } 0.057\end{array}$ & Todd County 36N32W22 & $\begin{array}{l}\text { Rahn and Paul, } \\
1975\end{array}$ \\
\hline Aquifer test & No & 2,995 & 21.6 & -- & 0.02 & Todd County 37N29W31CCA & $\begin{array}{l}\text { Kremlin-Smith, } \\
1984\end{array}$ \\
\hline Aquifer test & No & 1,644 & 7.9 & -- & 0.03 & Todd County 36N29W14CAC & $\begin{array}{l}\text { Kremlin-Smith, } \\
1984\end{array}$ \\
\hline Aquifer test & No & 3,088 & 17.5 & -- & 0.02 & Todd County $37 \mathrm{~N} 29 \mathrm{~W} 8 \mathrm{ABB}$ & $\begin{array}{l}\text { Kremlin-Smith, } \\
1984\end{array}$ \\
\hline Specific capacity & No & $180-3,476$ & $1.2-25.2$ & -- & -- & Todd County & $\begin{array}{l}\text { Kremlin-Smith, } \\
1984\end{array}$ \\
\hline Specific capacity & No & $\begin{array}{l}2-2,400 \\
\text { mean } 600\end{array}$ & -- & -- & -- & Todd County & Carter, 1998 \\
\hline $\begin{array}{l}\text { Specific capacity } \\
\text { and other data }\end{array}$ & No & -- & $0.2-120$ & -- & -- & Todd and Mellette Counties & $\begin{array}{l}\text { Long and others, } \\
2003\end{array}$ \\
\hline $\begin{array}{l}\text { Inverse modeling } \\
\text { techniques }\end{array}$ & No & -- & $0.2-84.4$ & -- & -- & Todd and Mellette Counties & $\begin{array}{l}\text { Long and others, } \\
2010\end{array}$ \\
\hline Unknown & Yes & $\begin{array}{l}800-9,200 \\
\text { mean } 2,800\end{array}$ & -- & -- & -- & $\begin{array}{l}16 \text { wells to the south and south- } \\
\text { west of Tripp County within } \\
100 \text { miles of Tripp County }\end{array}$ & Newport, 1959 \\
\hline
\end{tabular}

High Plains aquifer ${ }^{\mathrm{c}}$

\begin{tabular}{ccccccc}
\hline $\begin{array}{c}\text { Grain size } \\
\text { descriptions }\end{array}$ & Yes & -- & $\begin{array}{c}3.6-160 ; \\
\text { mean } 30\end{array}$ & -- & $0-0.25$ & $\begin{array}{c}\text { Tripp County } \\
\text { Kolm and Case, } \\
1983\end{array}$ \\
\hline
\end{tabular}

${ }^{a}$ Calculated from a transmissivity based on saturated thickness of 58 feet.

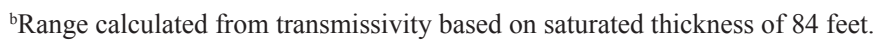

'Includes Ogallala aquifer and Arikaree aquifer.

\section{Recharge}

Recharge to the Ogallala aquifer occurs from infiltration of precipitation on the outcrop of the Ogallala Formation and the overlying Quaternary-age deposits in the study area (Long and Putnam, 2010). Data were available for 13 National Oceanic and Atmospheric Administration (NOAA) climate stations in and surrounding the study area, 8 of which are within the study area (fig. 11; National Oceanic and Atmospheric Administration, 2010). The mean annual precipitation for WYs 1985-2009 for these stations was $22.9 \mathrm{in}$.

Recharge to the Ogallala aquifer for WYs 1985-2009 was estimated using the Soil-Water-Balance (SWB) software program of Westenbroek and others (2010) to calculate recharge based on a modified Thornthwaite-Mather SWB approach (Thornthwaite, 1948; Thornthwaite and Mather, 1957). The
SWB program uses climate data, land-use characteristics, hydrologic soil properties, surface-water flow direction, and available soil-water capacity to calculate recharge for individual model cells. The SWB program calculates recharge as the difference between the sources and sinks of water and the change in soil moisture. A full description of the SWB method used to determine recharge to the Ogallala aquifer is available in supplement 3.

Two separate recharge simulations were completed using different climate inputs for the SWB program. Recharge calculated by the SWB program was based on climate data from stations located in the towns of Winner (station 399367) and Gregory (station 393452), S. Dak. (fig. 11; National Oceanic and Atmospheric Administration, 2010). The SWB program calculated recharge based on daily climate data from each station. The results of each simulation were averaged on a 


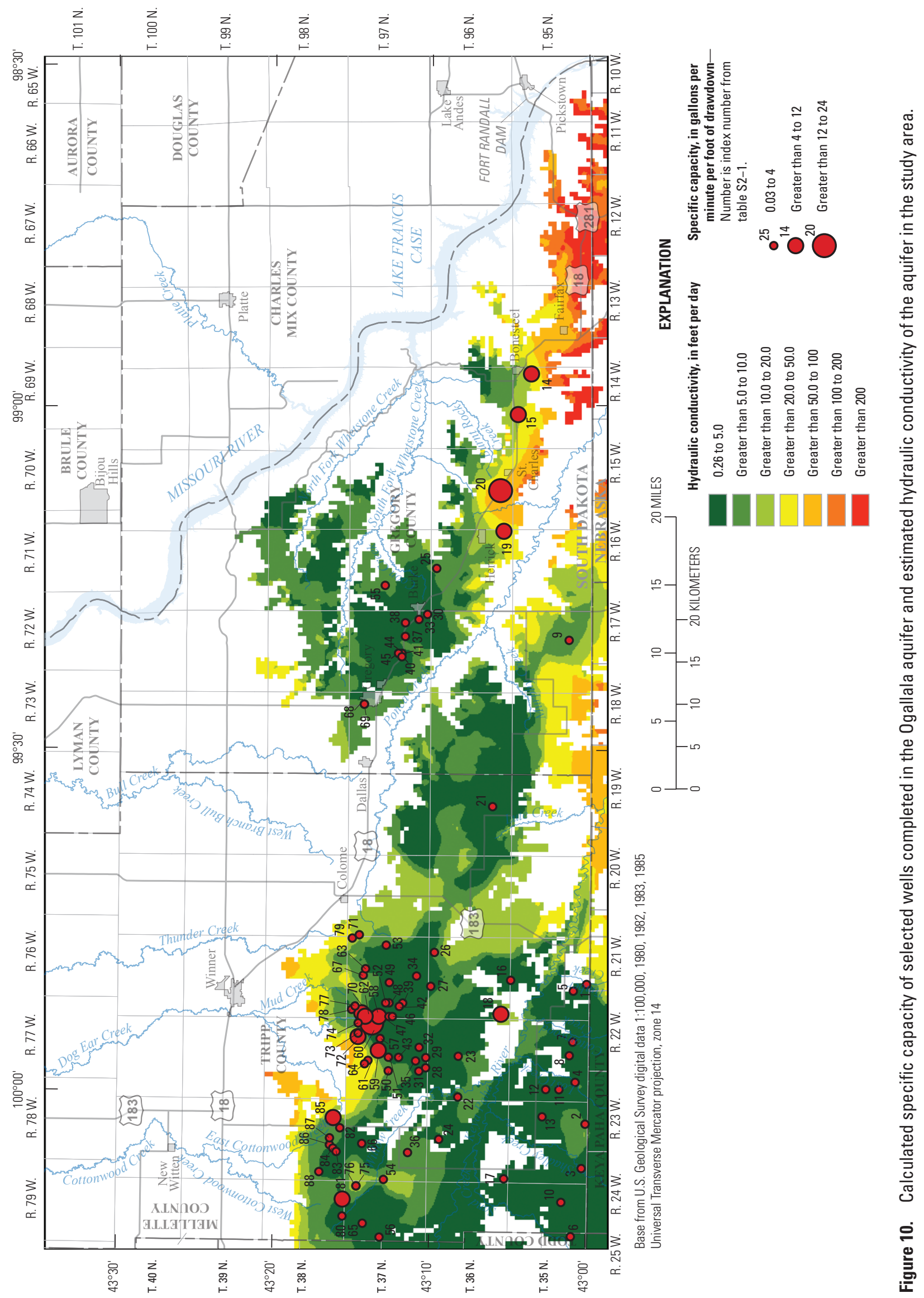



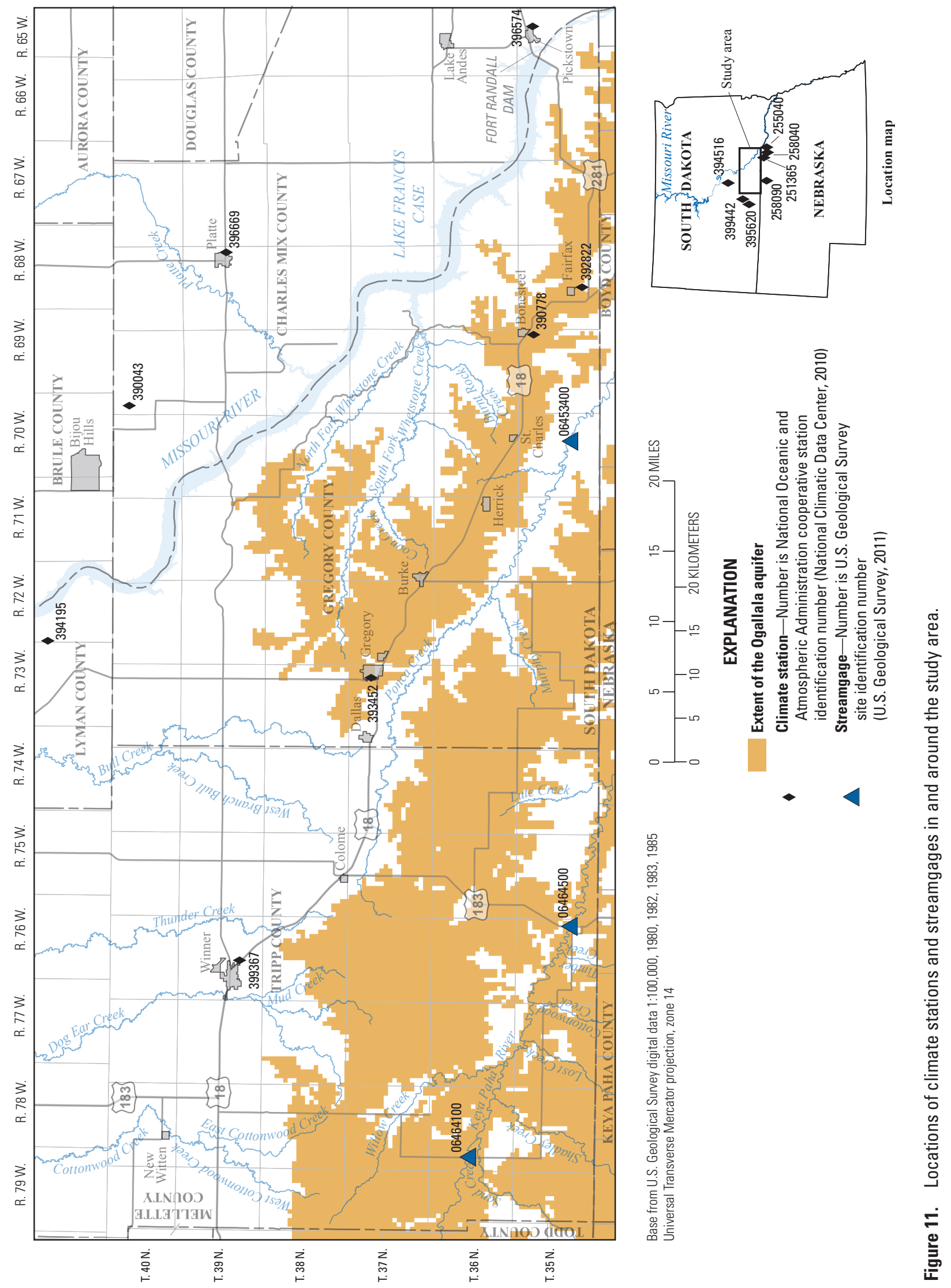
cell-by-cell basis and aggregated by stress period. Recharge calculated using the SWB method varies spatially within the study area; therefore, the results of the SWB method in this report represent spatially averaged rates for the part of the study area underlain by the Ogallala aquifer.

Estimated annual recharge for the Ogallala aquifer in the study area generally ranged from 0.51 to $5.94 \mathrm{in}$., with a mean of 3.14 in. (table 4). For the study area, this represents a mean total recharge rate of $239 \mathrm{ft}^{3} / \mathrm{s}$. Seasonally, mean recharge for the study area varied from as low as zero in the summer months (stress periods 15, 48, 54, and 57) to as high as $5.43 \mathrm{in}$. in the spring months (stress period 32; table 4). Annually, recharge generally was highest during the spring stress periods (March through May) and lowest during the summer stress periods (June through September). On average, calculated recharge was 12.1 percent of precipitation for the study area. The spatial distribution of mean annual recharge for SWB model cells for WYs 1985-2009 ranged from 0.1 to $15.4 \mathrm{in}$. across the study area (fig. 12).

The recharge rates estimated using the SWB method were compared with previous estimates of recharge for the Ogallala aquifer. The 25-year mean recharge of 3.14 inches per year (in/yr) (12.1 percent of precipitation) estimated by the SWB method for the Ogallala aquifer in Gregory and Tripp Counties generally was similar to previously published estimates of recharge for the aquifer. Previous estimates of recharge include 15 percent of precipitation or $3.4 \mathrm{in} / \mathrm{yr}$ for the study area (Langbein, 1949). Kolm and Case (1983) estimated recharge to the Ogallala aquifer in the study area to be 8 percent of annual precipitation or $1.8 \mathrm{in} / \mathrm{yr}$. Newport (1959) estimated 1-2 in/yr of recharge to the aquifer for the lower Niobrara River (fig. 1), which includes the Keya Paha River and Ponca Creek drainage basins (fig. 3). LaBelle (2011) estimated recharge to the Ogallala and Arikaree aquifers in Bennett, Jackson, and Shannon Counties in South Dakota, which are located immediately west of Mellette and Todd Counties, using the SWB program; the mean recharge to the Ogallala aquifer between 1970 and 2009 was estimated to be $3.28 \mathrm{in} / \mathrm{yr}$.

Previously published estimates of recharge for the Ogallala aquifer provide a reasonable representation of recharge to the aquifer, but these estimates generally are only defined as a constant percentage of precipitation. The SWB program calculates spatially and temporarily variable recharge based on multiple input data. For these reasons, the results of the SWB program are considered an improvement compared with previous estimates of recharge for the Ogallala aquifer.

\section{Discharge}

Discharge from the Ogallala aquifer occurs through evapotranspiration, discharge to streams, and well withdrawals. Discharge by evapotranspiration generally occurs in topographically low areas or where the water table is near the land surface. Discharge to streams occurs as flow from springs and seeps and as base flow where the aquifer is hydraulically connected to the streams (river leakage). For the purpose of this analysis, all discharge from springs and seeps was assumed to reach a stream and contribute to base flow. Well withdrawals are from irrigation, public supply, domestic, and stock wells.

\section{Evapotranspiration}

Evapotranspiration represents the amount of water removed from the saturated groundwater regime by plant transpiration and direct evaporation from groundwater in the saturated and unsaturated zone (Wilson and Moore, 1998). Evapotranspiration from groundwater occurs when the water table is at or near the land surface; therefore, evapotranspiration generally occurs in topographically low areas, such as river valley bottoms (Long and Putnam, 2010). When the water table is at the land surface, evapotranspiration is greater than when the water table is below the land surface. Potential evapotranspiration represents the maximum amount of groundwater that could be evapotranspired if the system is not water-limited. Evapotranspiration is assumed equal to the maximum potential evapotranspiration rate when the water table is at the land surface, and it decreases linearly to zero when the water table is beneath the root zone. For the study area, the rate of evapotranspiration is a product of the surface vegetation, depth of the root zone, and depth to water, where applicable.

The SWB method was used to calculate estimates for maximum potential evapotranspiration for the study area, in addition to recharge, as described in supplement 3 . The SWB method can be used to calculate potential evapotranspiration based on five commonly used evapotranspiration methods (Westenbroek and others, 2010). Calculations of evapotranspiration for the study area using the SWB program were based on methods developed by Hargreaves and Samani (1985), which incorporate the latitudinal location of the study area and maximum and minimum daily temperatures. The other four evapotranspiration methods available to the SWB program were not used because they required humidity and wind speed, which were not available.

The maximum potential evapotranspiration estimated with the SWB method for the 25 summer stress periods (third stress period for each water year) ranged from 19.1 to $22.0 \mathrm{in}$. (table 5), with a mean of 20.6 in.. Estimated mean maximum potential evapotranspiration for the fall/winter and spring stress periods (first and second stress periods for each water year, respectively) was 0.7 and 4.1 in., respectively. Estimates from the SWB method indicate an annual mean maximum potential evapotranspiration of $25.4 \mathrm{in} / \mathrm{yr}$ for the study area (table 5). This does not represent the actual amount of water removed from the saturated groundwater regime; rather, it represents the maximum amount of water that could be removed if there was never a deficiency of water in the soil for use by vegetation (Wilson and Moore, 1998).

The evapotranspiration rates estimated using the SWB method for this study were compared with previous estimates of evapotranspiration of the Ogallala aquifer to examine plausible ranges for the estimates. Farnsworth and others (1982) 


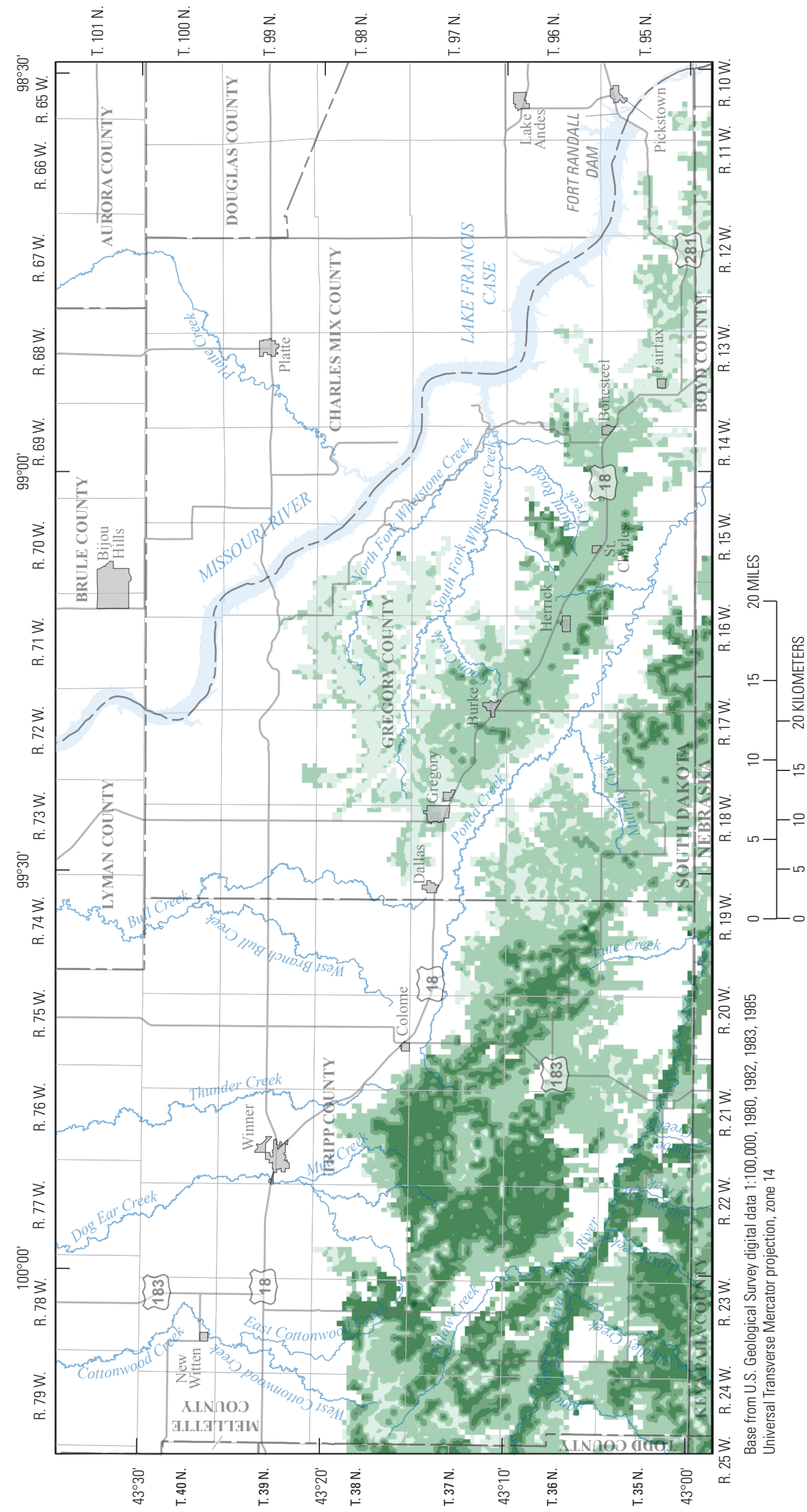

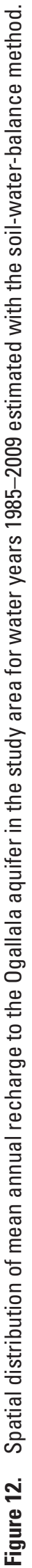


Table 4. Recharge to the Ogallala aquifer in the study area estimated by using the soil-water-balance method, water years 1985-2009. $[--$, not applicable $]$

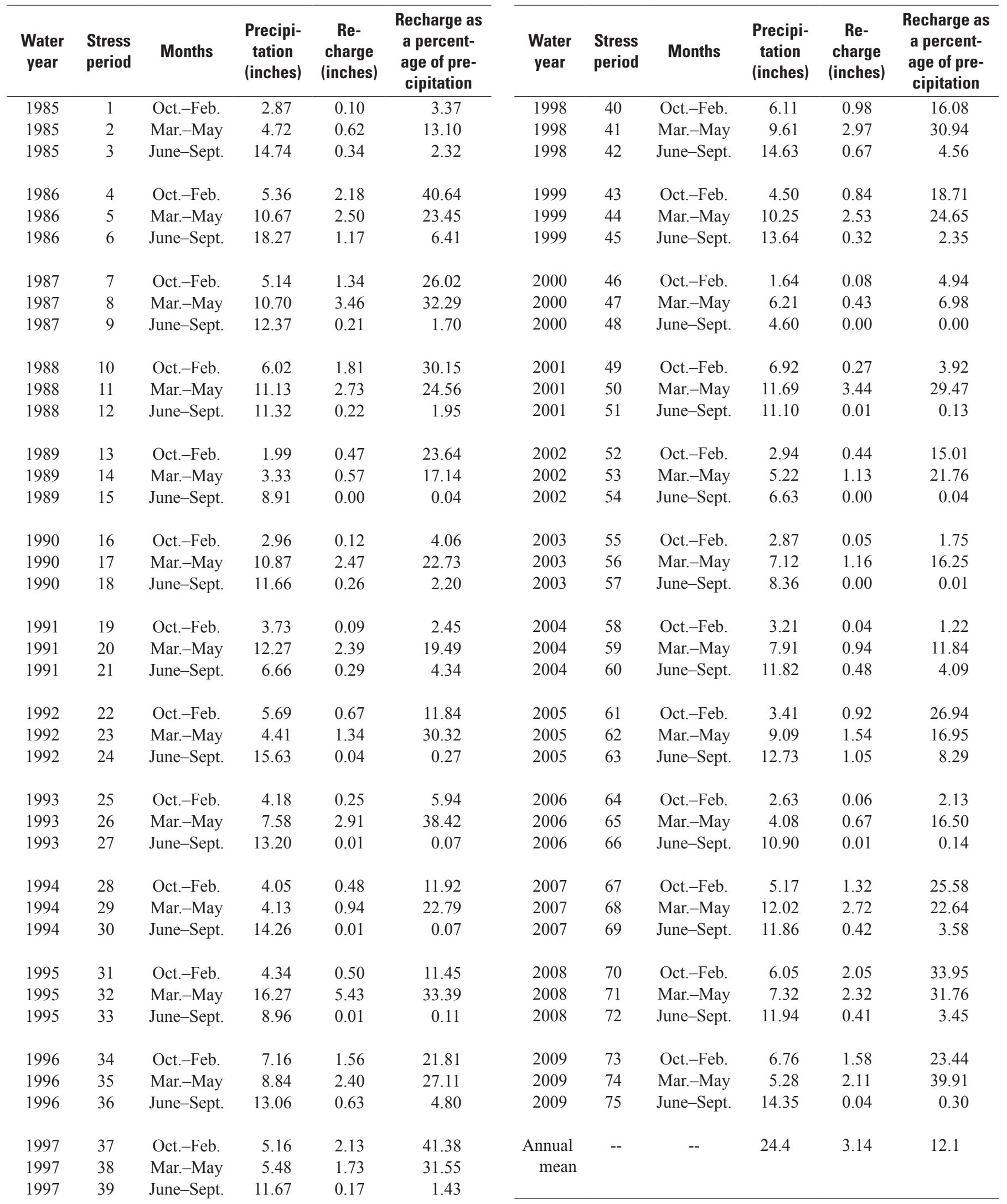


Table 5. Measured pan evaporation at Pickstown, South Dakota, and maximum potential evapotranspiration estimated by using the soil-water-balance method, water years 1985-2009.

[--, not applicable]

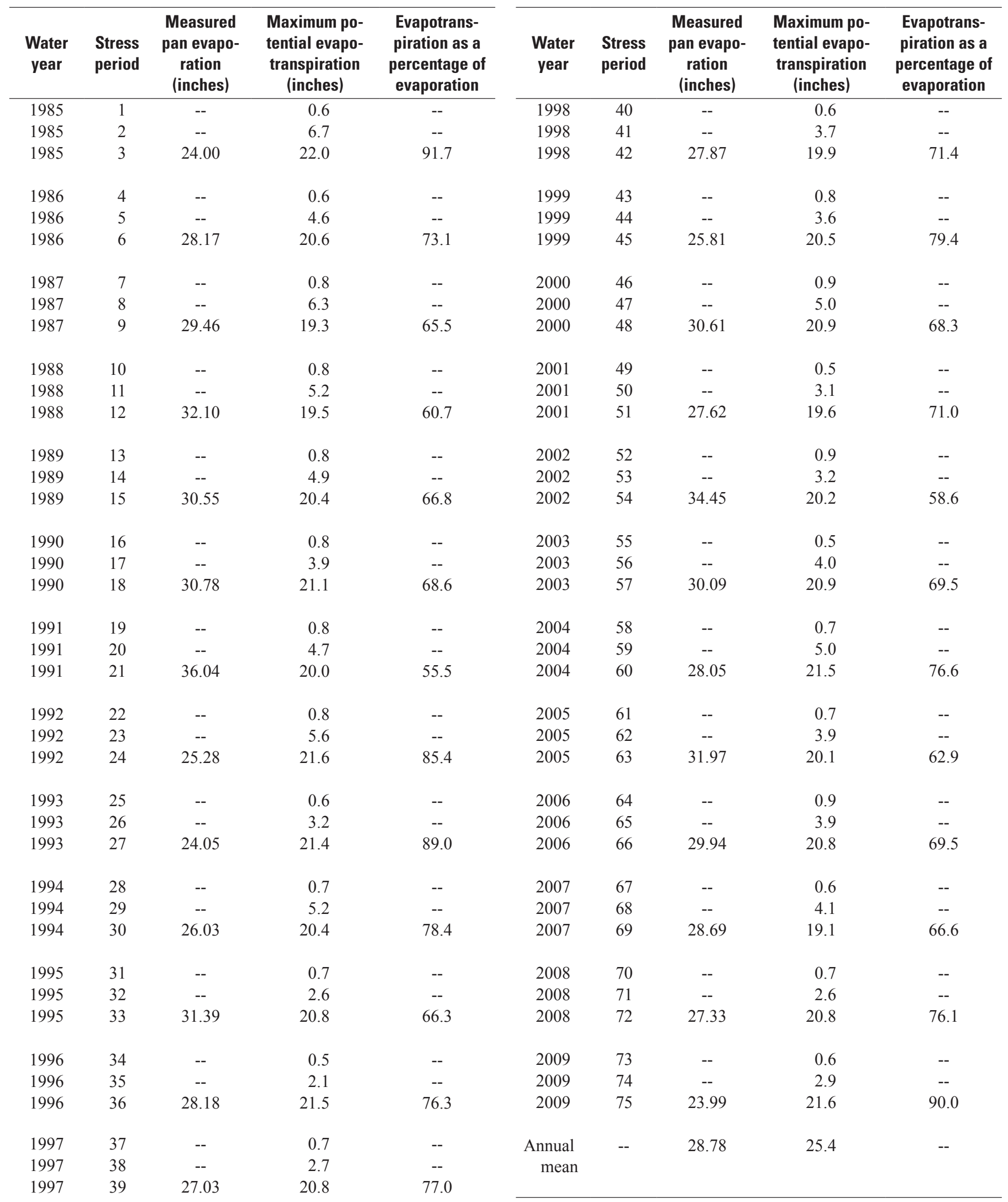


estimated maximum evapotranspiration for the Ogallala aquifer to be 70 percent of pan evaporation. Pan evaporation rates for the study area were assumed to be similar to those measured at the NOAA climate station at Pickstown, S. Dak. (station 396574; fig. 11; National Oceanic and Atmospheric Administration, 2010). Pan evaporation records were available for June through September for the 25 water years of the analysis period (table 5). Multiplying the pan evaporation records by the 70 percent estimate of Farnsworth and others (1982) yielded estimated maximum evapotranspiration for the summer months ranging from 16.8 to 26.2 in., with a mean of 20.4 in. These estimates are similar to those estimated using the SWB method for the summer stress periods. Sparse pan evaporation data were available for the fall, winter, and spring months. Long and Putnam (2010) estimated evapotranspiration rates of 2.1 and 6.3 in., respectively, for the fall/winter and spring stress periods, based on pan evaporation rates recorded at the NOAA climatological data station at Cottonwood, S. Dak., which is approximately 90 miles (mi) westnorthwest of the study area in Jackson County.

The maximum potential evapotranspiration for the summer stress periods estimated using the SWB method was compared with the measured pan evaporation at Pickstown (table 5). Calculations of maximum potential evapotranspiration generally averaged about 73 percent of total pan evaporation during the summer stress periods. Pan evaporation measurements for the fall/winter and spring stress periods were sparse; therefore, the maximum potential evapotranspiration estimated by the SWB method for the fall/winter and spring stress periods was not compared with measured pan evaporation data. The evapotranspiration rates estimated using the SWB method for the study area were similar to previously estimated evaporation rates for the Ogallala aquifer and thus deemed to be reasonable estimates. On the basis of relative accuracy of the evapotranspiration rates estimated using the SWB method for the summer stress periods, the SWB estimates of evapotranspiration for the fall/winter and spring stress periods were assumed to be reasonable, even though pan evaporation records for those months were not available for comparison.

\section{Discharge to Streams}

Springs and seeps discharge groundwater to streams in the study area. The Keya Paha River, Ponca Creek, and the North Fork and South Fork Whetstone Creek are the major streams in the study area that likely receive discharge from the Ogallala aquifer based on groundwater-flow directions (fig. 7). Base flow is the part of stream discharge that is not attributable to direct runoff from precipitation or melting snow (Wilson and Moore, 1998), and base flow is considered to occur as discharge through springs, seeps, and the hydraulic connection between the aquifer and streams flowing over it (river leakage).

Base flow in the Keya Paha River in the study area was estimated for WYs 1985-2009 using the hydrograph separation (partitioning) program PART (Rutledge, 1998). The PART program uses hydrograph separation methods on continuous streamflow data to estimate a daily record of base flow. The discharge from the Ogallala aquifer to the Keya Paha River in the study area was estimated to be the difference between the base flow estimated for the farthest upstream streamgage and the base flow estimated for the farthest downstream streamgage. Long-term streamflow records from upstream streamgage 06464100 (Keya Paha River near Keyapaha, S. Dak.) and downstream streamgage 06464500 (Keya Paha River at Wewela, S. Dak.) were used to estimate mean monthly discharge from the Ogallala aquifer to the Keya Paha River in the study area as base flow (fig. 11; U.S. Geological Survey, 2011). Streamflow measurements are given a rating such as excellent if the measurement is within 2 percent of the actual flow, good if within 5 percent, fair if within 8 percent, and poor if greater than 8 percent (Rantz and others, 1982).

For the time period used to calculate base flow, 58 percent of measurements were rated good, 29 percent were rated fair, and 13 percent were rated poor (U.S. Geological Survey, 2011). The estimated annual mean base flow of the Keya Paha River between Keyapaha and Wewela was $35.8 \mathrm{ft}^{3} / \mathrm{s}$ for WYs 1985-2009 (table 6).

Base flow estimated using the PART program (table 6) generally increased dramatically from the fall/winter stress period (October through February) to the spring period (March through May). Actual base flow probably does not fluctuate to this magnitude, and the large increases in estimated base flow during the spring months probably include a component of shallow interflow that occurs after periods of high precipitation and possibly some direct runoff (Long and others, 2003). The fall/winter stress periods alone probably provide a better estimate of base flow, because these periods generally are not affected by recent precipitation. Springtime base flow was assumed to increase somewhat compared with the fall/winter stress period, but the magnitude of base flow estimated using the PART program likely was an overestimation of actual base flow during the spring months.

To account for the overestimation, base flow for the spring stress period was calculated as the fall/winter base flow plus 25 percent of the increase between the fall/winter stress period and the spring stress period. The base flow for the summer stress period was then estimated as the mean base flow of the two previous periods. The adjustment between the fall/ winter stress period and the spring stress period, as described in Long and others (2003), was used by Long and Putnam (2010) for the Keya Paha River upstream from Tripp County and was considered to be applicable for the Kaya Paha River in the study area. The base-flow estimates were then increased by 4 percent to account for a possible underestimation of annual base flow in the study area (table 6).

A large component of the base flow for the Keya Paha River is likely to be discharge from springs and seeps that originate in the Ogallala aquifer. Additionally, Sand, Shadley, Willow, Lost, Cottonwood, and Timber Creeks drain into the Keya Paha River between the streamgages (06464100 and 
Table 6. Discharge to the Keya Paha River as base flow estimated using hydrograph separation, water years 1985-2009.

$[--$, not applicable $]$

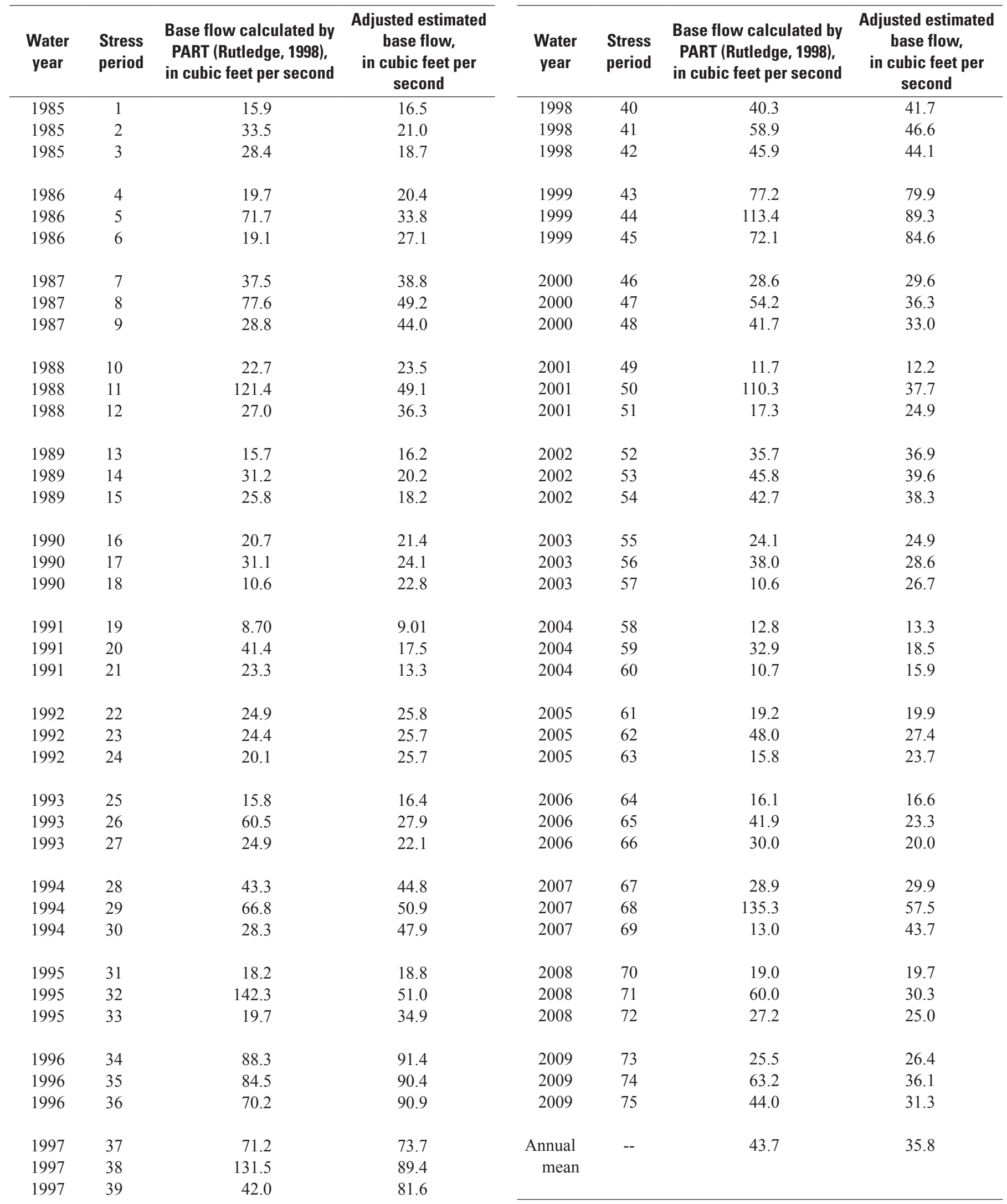


06464500) that were used to estimate base flow (fig. 11). Other smaller tributaries also drain into the Keya Paha River between these two streamgages. These small streams are likely to be fed by seeps or springs that originate from the Ogallala aquifer. The total base-flow gain between the two streamgages, as estimated using the PART program (table 6), was assumed to be the sum of the discharge from springs adjacent to the Keya Paha River; seeps along the Keya Paha River and Sand, Shadley, Willow, Lost, Cottonwood, and Timber Creeks; and the hydraulic connection between the aquifer and streams through riverbed material.

Ponca Creek, in the eastern part of the study area (figs. 3 and 11), likely obtains its base flow from small springs and seeps that originate in the Ogallala aquifer at the contact between the Ogallala Formation and the underlying Pierre Shale. Intermittent streamflow data were available for Ponca Creek from 1960 through 1974 at streamgage 06453400 (Ponca Creek near Naper, Nebr.; U.S. Geological Survey, 2011). Streamflow measurements from October through December of each year were assumed to have little effect from precipitation and runoff. The mean streamflow during those months from 1960 through 1974 was assumed to represent the mean discharge as flow from springs and seepage from the Ogallala aquifer for the Ponca Creek drainage basin, which was $3.85 \mathrm{ft}^{3} / \mathrm{s}$.

Streamflow data were not available for the North Fork and South Fork Whetstone Creek and smaller streams in the study area (fig. 11); therefore, discharge from the Ogallala aquifer into these streams was not estimated for the conceptual model. Smaller streams are mainly intermittent, runoff-fed streams during periods of high precipitation (Newport, 1959).

\section{Well Withdrawals}

Well withdrawals in the study area are primarily for irrigation and public supplies but also for domestic and stock use. Irrigation withdrawals are variable because they are affected by numerous factors, such as climatic conditions, commodity prices, and energy costs. The locations of irrigation wells (fig. 13) in Gregory and Tripp Counties were interpreted from driller's logs (Ken Buhler, South Dakota Department of Environment and Natural Resources, written commun., 2009) and SDDENR water-use permits (South Dakota Department of Environment and Natural Resources, 2011).

Water-use data for irrigation are compiled every 5 years as part of the USGS National Water-Use Information Program in cooperation with Federal, State, and local agencies. The information is aggregated by counties for each State (U.S. Geological Survey, 2009). Data on irrigation withdrawals for the Ogallala aquifer in Gregory and Tripp Counties were obtained from the USGS Site-Specific Water-Use Data System (SWUDS) for the period of available record. The SWUDS database includes water use reported by operators under specific water-use permits. Data for 19 irrigation wells existed for the available period of record (WYs 1985-2005). On the basis of completion information in driller's logs and water-use permits, it was assumed that the 19 irrigation wells were completed in the Ogallala aquifer. The data available for the 19 wells indicated that some wells were pumped annually for the period of record, others were pumped intermittently, and others reported no pumping. Reported annual records were used to determine irrigation withdrawals for WYs 1985-2005 (table 7). Withdrawals for WYs 2006-2009 were assumed to be equal to the 2005 reported values. The mean irrigation withdrawal rate for WYs 1985-2009 was $4.5 \mathrm{ft}^{3} / \mathrm{s}$ for the 4-month irrigation season (June through September), which equates to an annual irrigation withdrawal rate of $1.1 \mathrm{ft}^{3} / \mathrm{s}$.

Public supply use accounts for most of the groundwater withdrawal from the Ogallala aquifer in Gregory and Tripp Counties. The locations of production wells (fig. 13) were approximated from specific water-use permits and licenses (South Dakota Department of Environment and Natural Resources, 2011). Estimates of public supply withdrawals were based on the mean reported per capita use for Winner, Gregory, Colome, the Tripp County Water User District, and the East Gregory County Rural Water System (table 8). Withdrawals for Winner were estimated using mean withdrawals for 2012 (City of Winner, 2012). Withdrawals for Gregory were based on withdrawals for 2008 (South Dakota Department of Environment and Natural Resources, 2011). Rates for per capita use for Bonesteel, Burke, and Herrick were assumed to be equal to the per capita use for Colome and were based on withdrawal rates for 1965-1968 (South Dakota Department of Environment and Natural Resources, 2011). The per capita use for the Tripp County Water User District was estimated based on present (2012) withdrawals and the number of connections served by the district (Tripp County Water User District, 2012), with the assumption that each connection served a mean of three persons. Withdrawals for the East Gregory County Rural Water System were estimated based on an average water-use scenario for 1977 (South Dakota Department of Environment and Natural Resources, 2011). It was assumed that the per capita use did not change substantially between 1965 and 2012, and the reported per capita use was used without adjustment for WYs 1985-2009.

The maximum per capita use for public supply was assumed to occur and be at that constant rate during summer (June to September). The minimum per capita use for public supply was assumed for the remaining months (table 8). Estimated withdrawals from the Ogallala aquifer for public supply were calculated using per capita use and the population served. The population served was assumed to be equal to the town's population in 2000 (table 8; U.S. Census Bureau, 2002). The per capita use was multiplied by the estimated population served to calculate minimum and maximum withdrawal rates for the analysis period. The aggregate minimum and maximum water use for each water year represents the mean estimated annual withdrawal. Annual public supply use was estimated to be $4.38 \mathrm{ft}^{3} / \mathrm{s}$. Estimated water use was assumed to not fluctuate during the analysis period; therefore, withdrawals for public supply were assumed to be a constant annual rate for the analysis period. 

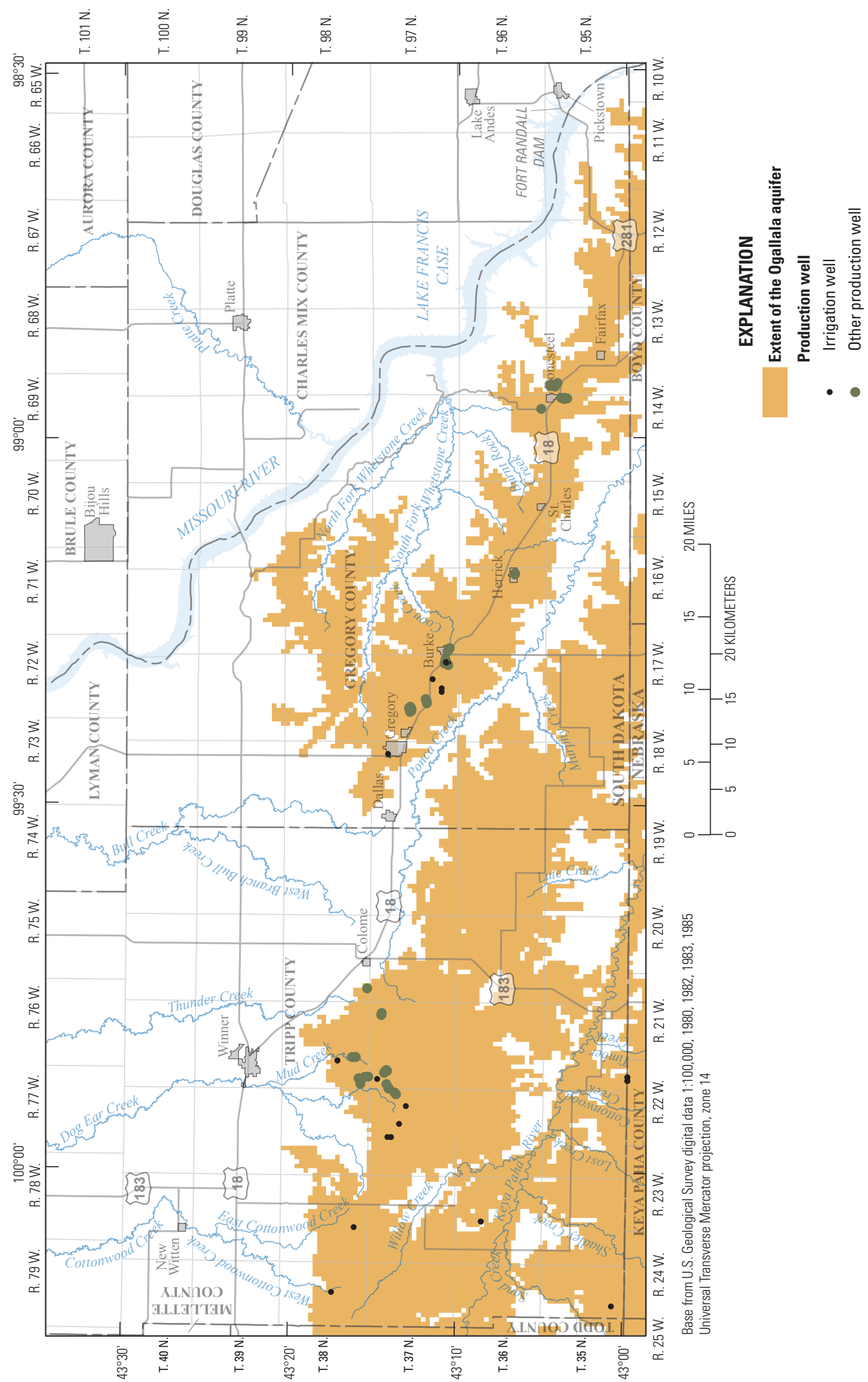

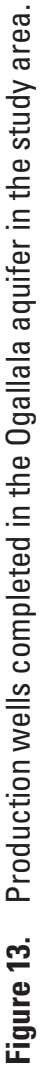


Table 7. Estimated withdrawals from the Ogallala aquifer for irrigation use in the study area, water years 1985-2009.

\begin{tabular}{|c|c|c|}
\hline \multirow{2}{*}{ Water year } & \multicolumn{2}{|c|}{ Irrigation withdrawals } \\
\hline & Acre-feet & Cubic feet per second ${ }^{a}$ \\
\hline 1985 & 629 & 2.6 \\
\hline 1986 & 774 & 3.2 \\
\hline 1987 & 895 & 3.7 \\
\hline 1988 & 968 & 4.0 \\
\hline 1989 & 2,250 & 9.3 \\
\hline 1990 & 1,476 & 6.1 \\
\hline 1991 & 1,113 & 4.6 \\
\hline 1992 & 605 & 2.5 \\
\hline 1993 & 508 & 2.1 \\
\hline 1994 & 944 & 3.9 \\
\hline 1995 & 774 & 3.2 \\
\hline 1996 & 920 & 3.8 \\
\hline 1997 & 895 & 3.7 \\
\hline 1998 & 847 & 3.5 \\
\hline 1999 & 823 & 3.4 \\
\hline 2000 & 1,089 & 4.5 \\
\hline 2001 & 1,041 & 4.3 \\
\hline 2002 & 1,863 & 7.7 \\
\hline 2003 & 1,234 & 5.1 \\
\hline 2004 & 1,355 & 5.6 \\
\hline 2005 & 1,283 & 5.3 \\
\hline 2006 & 1,283 & 5.3 \\
\hline 2007 & 1,283 & 5.3 \\
\hline 2008 & 1,283 & 5.3 \\
\hline 2009 & 1,283 & 5.3 \\
\hline Mean & 1,097 & 4.5 \\
\hline
\end{tabular}

${ }^{a}$ Withdrawal rate based on a 4-month irrigation season (June-September).

Private domestic and stock wells that exist within the study area were not included in the analysis because the total withdrawals from domestic and stock wells are assumed to account for a small fraction of the total water budget for the study area. The estimated combined mean annual withdrawal from production wells (irrigation and public supply) was $5.48 \mathrm{ft}^{3} / \mathrm{s}$.

\section{Numerical Model}

The numerical groundwater-flow model of the Ogallala aquifer described in this report represents WYs 1985-2009 and was developed from the data included in the conceptual model. The numerical model was used for transient simulations of historical conditions and potential future scenarios. The model was temporally discretized into one transient
200 -year initialization stress period followed by 75 seasonal stress periods for simulating transient conditions for WYs 1985-2009. The 200-year initialization period was simulated in order to define the starting conditions for the transient simulation.

\section{Simulation Methods}

This section describes the methods used to simulate groundwater flow in the Ogallala aquifer. The numerical model was developed to simulate groundwater flow, groundwater withdrawals, groundwater levels, and the interactions between streams and the Ogallala aquifer in Gregory and Tripp Counties. The simulation was completed using MODFLOWNWT (Niswonger and others, 2011), a newtonian formulation of MODFLOW-2005 (Harbaugh, 2005). MODFLOW-2005 can be used to simulate two- and three-dimensional groundwater flow through an aquifer by means of a finite difference solution technique.

The study area is subdivided into a grid of discrete cells, and flow into and out of each model cell is calculated by MODFLOW-2005. The actual hydrogeologic system is continuous rather than discrete; therefore, groundwater-flow simulations are always an approximation of the actual system. The study area was simulated using a single-layer, uniformly spaced grid of 133 rows oriented east-west and 282 columns oriented north-south. All grid cells were 500 meters (m; $1,640 \mathrm{ft}$ ) on each side (fig. 14).

A 200-year stress period was used as an initialization part of the simulation where the mean of aquifer stresses for the period were applied, and it provided the starting conditions for the subsequent 75 transient seasonal stress periods. The 200-year initialization stress period used mean rates of recharge, evapotranspiration, base flow, discharge from springs, and well withdrawals for WYs 1985-2009. The 200-year stress period was simulated in transient mode because the simulation was more stable and converged more quickly than one steady-state stress period. It was determined that 200 years was a sufficient amount of time to reproduce equilibrium conditions because simulated change in groundwater storage was close to zero. Time-varying values were used for the 75 transient seasonal stress periods and for numerical model calibration. The 200 -year initialization stress period was calibrated to steady-state conditions, and the 75 seasonal stress periods were calibrated to transient conditions for each period. Calibration objectives for the simulation included (1) simulating the long-term mean potentiometric surface and hydraulic gradients to those of the mapped potentiometric surface, (2) balancing inflows and outflows for the steady-state part of the simulation, (3) matching trends in hydrographs and hydraulic heads for the 38 State observation wells at 95 percent of wells to within plus or minus $( \pm) 25 \mathrm{ft}$ of observed hydraulic heads, and (4) matching the trends in the base-flow hydrograph for the Keya Paha River. 
Table 8. Estimated per capita use and withdrawals from the Ogallala aquifer for public supply in the study area.

[TCWUD, Tripp County Water User District; EGCRWS, East Gregory County Rural Water System; --, not applicable]

\begin{tabular}{lcccccc}
\hline \multirow{2}{*}{ City or water use district } & \multicolumn{2}{c}{$\begin{array}{c}\text { Estimated daily per capita use } \\
\text { (gallons) }\end{array}$} & \multirow{2}{*}{$\begin{array}{c}\text { Estimated population served } \\
\text { (U.S. Census Bureau, 2002) }\end{array}$} & \multicolumn{2}{c}{$\begin{array}{c}\text { Withdrawal rate, } \\
\text { in cubic feet per second }\end{array}$} \\
\cline { 2 - 3 } & Minimum & Maximum & & & Minimum & Maximum \\
\hline Winner $^{\mathrm{a}}$ & 200 & 250 & 3,137 & - & 0.97 & 1.21 \\
TCWUD $^{\mathrm{b}}$ & 205 & 249 & 1,342 & 2.17 & 2.63 \\
Gregory $^{\mathrm{e}}$ & 154 & 174 & 340 & 0.32 & 0.36 \\
Colome $^{\mathrm{d}}$ & 100 & 200 & 676 & 0.05 & 0.11 \\
Burke $^{\mathrm{e}}$ & 100 & 200 & 105 & 0.10 & 0.21 \\
Herrick $^{\mathrm{e}}$ & 100 & 200 & 297 & 0.02 & 0.03 \\
Bonesteel $^{\mathrm{e}}$ & 100 & 200 & -- & 0.05 & 0.09 \\
EGCRWS $^{\mathrm{f}}$ & 275 & 300 & & & 0.37 & 0.40 \\
\hline
\end{tabular}

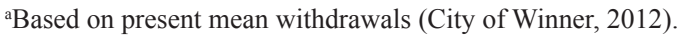

${ }^{b}$ Based on present mean withdrawals assuming three people per connection (Tripp County Water Users District, 2012).

'Based on 2008 withdrawals (South Dakota Department of Environment and Natural Resources, 2011).

dBased on withdrawal rates for 1965-1968 (South Dakota Department of Environment and Natural Resources, 2011).

Estimated based on per capita use for Colome, South Dakota.

fBased on an average water use scenario for 1977 (South Dakota Department of Environment and Natural Resources, 2011).

Simulations were calibrated by adjusting selected parameters within user-defined constraints until simulated groundwater levels and base flow reproduced measured values. The calibration process was accomplished using the Parameter Estimation (PEST) software program (Doherty, 2010), which is an open source, public domain software suite that systematically adjusts model input parameters in an attempt to match simulated and measured values. The software is accompanied by supplementary open source and public domain software applications for calibration of groundwater models (Doherty, 2008). In this report, parameter estimation is used to specifically describe the automated process of adjusting parameter values, using PEST, to match simulated and measured values for hydraulic head and base flow in the study area.

\section{Definitions}

This section describes terms specific to groundwater modeling that are used in the remainder of this report. Model malperformance as a result of dry cells often occurs when modeling unconfined aquifers (Niswonger and others, 2011). A dry cell is a grid cell that becomes dewatered during any part of the simulation (Niswonger and others, 2011). MODFLOW-2005 calculates flow between model cells on the basis of a conductance term. Conductance is defined as the product of the hydraulic conductivity and cross-sectional area of flow divided by the distance between cell centers (Harbaugh, 2005). For parts of the simulation, certain cells are designated as either constant specified head or time-variant specified head. Constant specified-head cells are cells that have a user-defined hydraulic head that remains constant during a stress period.
Time-variant specified-head cells are cells that have userdefined hydraulic head that changes from the start to the end of a stress period.

During model calibration, hydraulic conductivity parameters are estimated with the use of pilot points (Doherty, 2010). Pilot points are discrete locations distributed throughout the model domain (Doherty and Hunt, 2010) and represent surrogate parameters from which hydraulic property values are interpolated to the model grid (Doherty and others, 2010). Pilot points were subdivided further into multiple zones. Model zones are used to prevent parameters from being interpolated across zone boundaries and to represent the location of discrete changes in hydrogeologic properties in a model domain (Doherty, 2010).

\section{Assumptions}

Using MODFLOW-NWT to simulate groundwater-flow systems through finite-difference solution techniques implies many assumptions (Harbaugh, 2005). The primary assumptions that were made follow.

- Flow in the Ogallala aquifer in the study area is predominantly horizontal, and the aquifer is unconfined within the study area. The aquifer is therefore represented appropriately with a single model layer.

- The spatial variability in aquifer properties is adequately represented with uniform grid cells that are 1,640 by $1,640 \mathrm{ft}$ in size, and aquifer properties are uniform within the area of each cell. The sediments of the Ogallala aquifer are fluvial in origin and have a 


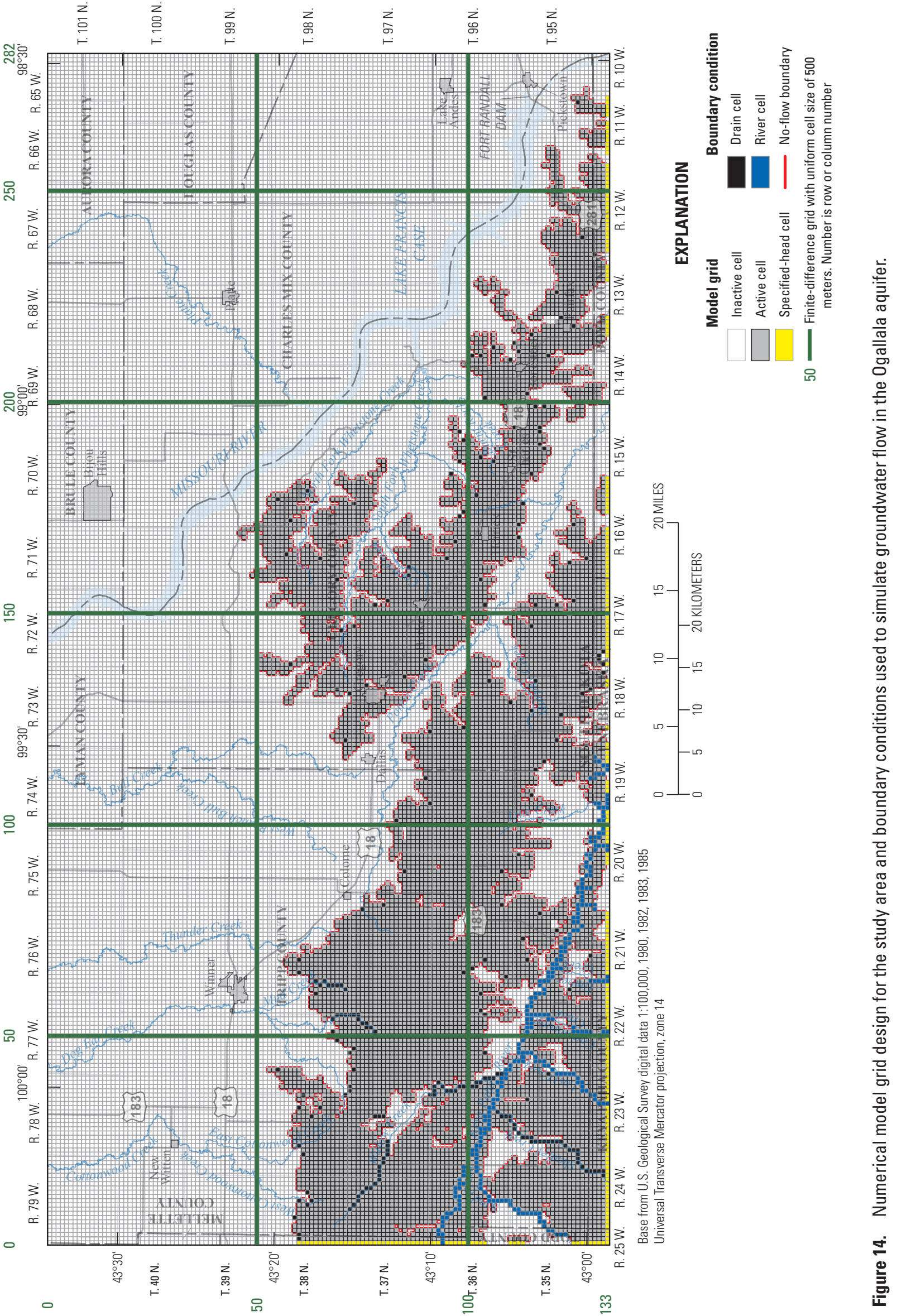


greater degree of vertical and horizontal heterogeneity than is represented by the current scale of the model. It is recognized that actual hydraulic properties at individual sites could vary widely from those represented in the model. A 1,640-ft grid spacing was assumed to be an appropriate discretization of the model to represent the heterogeneity of the Ogallala aquifer for the scale of the groundwater-flow model. Additionally, a 1,640-ft spacing was similar to that used by Long and Putnam (2010) to simulate groundwater flow in the High Plains aquifer in Mellette and Todd Counties directly to the west of the study area.

- Sources and sinks of water that have an important effect on the groundwater-flow system, such as streams, well withdrawals, and recharge, can be adequately simulated using a grid spacing of 1,640 by $1,640 \mathrm{ft}$. Streams in the study area actually are much less than 1,640 $\mathrm{ft}$ wide, but as with assumption 2, the 1,640 - $\mathrm{ft}$ spacing is sufficient discretization for the scale of the groundwater-flow model.

- Starting conditions for the 25-year transient simulation can be appropriately estimated with a 200-year transient initialization stress period. The 200 -year initialization stress period does not represent a steady-state condition. The initialization stress period represents a quasi-steady-state condition, and it provides adequate initial conditions for the transient 25 -year simulation. The mean of aquifer stresses was applied during the 200-year initialization stress period, and the simulated change in aquifer storage was close to zero. Therefore, this assumption seems appropriate.

- Sources and sinks of water that have an important effect on the groundwater-flow system were appropriately represented by three stress periods per water year. The stress periods represented fall/winter (October through February), spring (March through May), and summer (June through September). It is recognized that aquifer stresses exist at a higher degree of variability that is not represented by three stress periods per water year. Temporally varying stresses, such as well withdrawals, are smoothed and averaged compared with what may exist in reality. Although, as with assumptions 2 and 3, the degree of discretization used is appropriate for the scale of groundwater-flow model.

\section{Model Design}

MODFLOW-NWT (Niswonger and others, 2011) was used to simulate groundwater flow for the Ogallala aquifer in the study area. MODFLOW-NWT is a numerical, three-dimensional, finite-difference groundwater modeling program that uses many of the packages distributed with MODFLOW-2005. Additional packages used by
MODFLOW-NWT are either modified MODFLOW-2005 packages or new packages. The MODFLOW-NWT and MODFLOW-2005 packages that were incorporated into the model were documented in Niswonger and others (2011) and Harbaugh (2005), and included the Well, Drain, Evapotranspiration, River, Recharge, and Upstream Weighting (UPW) packages.

MODFLOW-2005 solver packages can encounter convergence problems if parts of the model domain become dewatered during a simulation. The UPW package is a new solver used by MODFLOW-NWT that provides a robust representation of dry cells in the model. The UPW package is useful for simulating flow in unconfined aquifer systems because it does not deactivate and subsequently reactivate dry cells during a simulation like MODFLOW-2005 solver packages would. Instead, the UPW package reduces the conductance between a dry cell and an adjoining cell to zero. This method keeps a dry cell active while not allowing water to flow out of a dry cell (Niswonger and others, 2011). The Well package is the only MODFLOW-2005 package that was modified for MODFLOW-NWT. The new Well package has the ability to reduce the pumping rate of a well located in a cell that is dewatered during a simulation. This method prevents water from being removed from a dewatered cell.

\section{Grid and Boundary Conditions}

The model grid consisted of one layer made up of 133 rows oriented east-west and 282 columns oriented north-south (fig. 14). The western part of the model grid overlaps the eastern part of the model of the Ogallala and Arikaree aquifers in Mellette and Todd County developed by Long and Putnam (2010) and has similar grid spacing. The height of each cell was equal to the mean estimated formation thickness. The model includes the parts of the aquifer that have a saturated thickness of $10 \mathrm{ft}$ or greater. The calculation of the formation thickness is described with more detail in the "Hydrogeologic Representation" section of this report.

Although the aquifer is considered unconfined in the study area, a requirement for MODFLOW-NWT simulations is that all cells are convertible between confined and unconfined conditions. Cells on the western and southern edges of the model domain were designated as specified-head cells (fig. 14), which were constant specified-head cells for the 200-year initialization stress period and time-variant specified-head cells for the transient part of the simulation. Most cells that represent the aquifer edges were simulated as no-flow boundaries. Rivers and streams were placed in locations where the mean potentiometric surface intersected the land surface in topographically low areas of river drainages that coincided with perennial stream reaches (fig. 14) and were simulated using the River package. Locations of springs and seeps were assumed to be along the edge of the aquifer (fig. 14) and were simulated using the Drain package. Ephemeral stream drainages at the edge of the Ogallala aquifer also were simulated as drains. Simulation of these cells as drains allowed water 
to flow out of the aquifer at the edge of the model where the groundwater flow was not approximately perpendicular to the aquifer edge.

\section{Hydrogeologic Representation}

The aquifer base was assumed to be the contact between the Ogallala aquifer and the low permeability units at the base of the aquifer. In the study area, these formations included the Pierre Shale, the White River Group, and the Arikaree Formation. The potentiometric surface and saturated thickness of the Ogallala aquifer were used to calculate the altitude of the base of the aquifer as described in the "Groundwater Flow" section of this report. Using the potentiometric surface (fig. 7), the saturated thickness of the aquifer (fig. 5) was subtracted from the water-table altitude (hydraulic head) to determine the base of the aquifer for each model cell. The formation thickness was then calculated by subtracting the base of the aquifer from the land-surface altitude within each cell.

\section{Representation of Hydraulic Properties}

Previously published values (table 3 ) and interpreted specific capacity and transmissivity data were used as general indicators for hydraulic conductivity; parameter estimation of hydraulic conductivity using PEST was used to interpret the final values and distributions. Values for horizontal hydraulic conductivity were estimated using pilot-point parameterization, described further in the "Model Calibration" section of this report. In contrast to subdividing the model into a subset of zones representing uniform hydraulic conductivity, pilotpoint parameterization allowed a smooth variation of hydraulic conductivity over the model domain.

Two separate pilot-point zones (HK1 and HK2) were used to simulate hydraulic conductivity in the Ogallala aquifer (fig. 15). Zone HK1 represented sediments west of Ponca Creek, and zone HK2 represented sediments east of Ponca Creek. Zone delineation was determined by considering potential structural features. Ponca Creek was assumed to be the approximate location of a zone boundary because of the potential structural effect of the location of Ponca Creek.

The Ogallala aquifer was represented with uniform storage coefficient and specific yield in the model. MODFLOWNWT requires specific storage for input and does not actually read storage coefficient. Therefore, a multiplier was assigned to each model cell to represent the inverse of the maximum saturated thickness of the cell. This value for each cell was multiplied by the uniform storage coefficient value to calculate specific storage for the model domain.

Calculated specific capacity (table S2-1) and the orientation of the potentiometric surface (fig. 7) indicated a high degree of heterogeneity within the aquifer. The heterogeneity was simulated by assuming horizontally and vertically anisotropic conditions within the aquifer. The anisotropy of the Ogallala aquifer was represented by directing PEST on how to interpolate hydraulic conductivity to the model domain based on the estimated values at pilot-point locations. The hydraulic conductivity interpolated to an individual model cell was more dependent on the estimated values from pilot points oriented in the major direction of anisotropy and less dependent on the values from pilot points oriented in the minor direction of anisotropy. The major direction and magnitude of anisotropy is assignable in PEST. The minor direction of anisotropy is oriented perpendicular to the major direction of anisotropy.

The direction and magnitude of anisotropy was determined by trial and error to improve model performance and is described further in the "Model Calibration" section of this report. Anisotropy was assumed to be different in each of the hydraulic conductivity zones (HK1 and HK2; fig. 15). The vertical hydraulic conductivity was assumed to be a uniform ratio of 10 percent of the horizontal hydraulic conductivity.

\section{Recharge}

The Recharge package (Harbaugh, 2005) was used to represent recharge to the Ogallala aquifer in the numerical model. Recharge to the model was estimated using the SWB method described in the "Water Budget Components" section of this report and supplement 3. One parameter (RCH1_TS) was used as a multiplier to optimize the SWB recharge estimates during the calibration process, as described in the "Model Calibration" section of this report. The mean annual recharge rate estimated for WYs 1985-2009 using the SWB method was used as the constant recharge rate for the 200-year transient initialization stress period. Monthly recharge rates estimated using the SWB method were aggregated for the 75 seasonal stress periods.

\section{Discharge}

Various MODFLOW-2005 packages were used to simulate the discharge components of evapotranspiration, discharge to streams, and well withdrawals. The Evapotranspiration package (Harbaugh, 2005) was designed to simulate evapotranspiration from the uppermost aquifer in any given cell where the water table is within a specified depth below the land surface, referred to as the extinction depth. The extinction depth was set to $10 \mathrm{ft}$ in areas of woody vegetation and $7 \mathrm{ft}$ elsewhere (fig. 3; Multi-Resolution Land Characteristics Consortium, 2009). The evapotranspiration rate is zero at the extinction depth and increases linearly to a maximum rate when the water level is at or above the land surface. The land surface of each model cell was calculated as the mean landsurface altitude for the area covered by the cell, based on a 30-m (98-ft) digital elevation model (DEM) of the study area (U.S. Geological Survey, 2006).

Land cover in the study area was generalized, and the rooting depths represent average ranges. The maximum depth of the root zone was based on previously published values and assumed to be approximately 7 to $10 \mathrm{ft}$ in the study area, with root penetration of $10 \mathrm{ft}$ attributed with trees (Canadell and others, 1996). Land cover for the study area was determined from land-use information obtained from the Multi-Resolution 

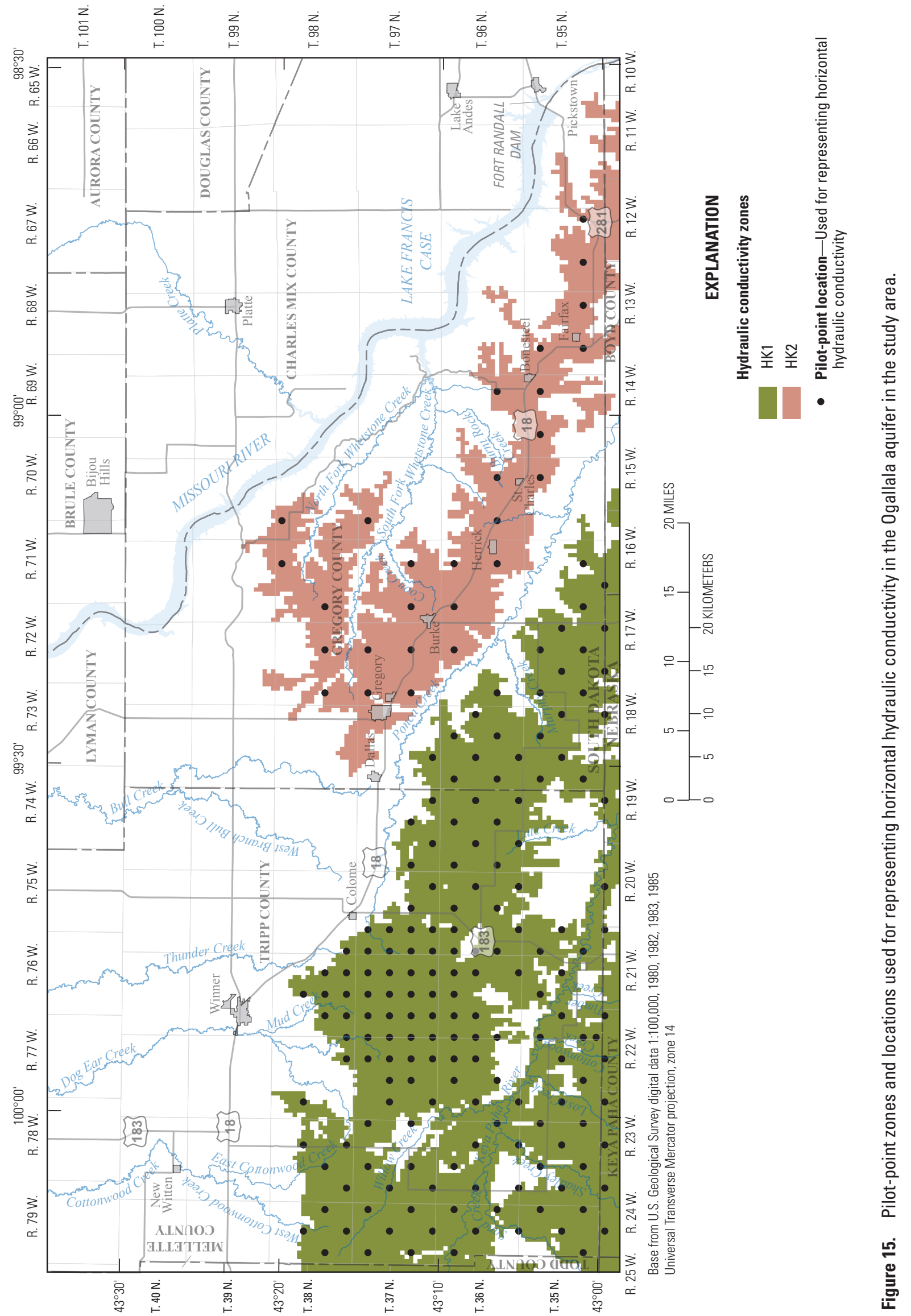
Land Characteristics Consortium (2009) to differentiate forested areas from grassland and agricultural areas. Forested areas generally occurred in the eastern part of Gregory County, west of the Missouri River (fig. 3). For forested areas, the extinction depth of evapotranspiration was set to $10 \mathrm{ft}$ below the land surface (Multi-Resolution Land Characteristics Consortium, 2009). All other regions of the model were assigned an extinction depth of $7 \mathrm{ft}$ (fig. 3).

The SWB program calculated the maximum potential evapotranspiration for each model cell, and these values were used in the Evapotranspiration package in which the parameter EVT1_TS was used as a multiplier to adjust for SWB error. The EVT1_TS parameter was optimized during the calibration process described in the "Model Calibration" section. The mean of the annual maximum potential evapotranspiration rates for each model cell, estimated for WYs 1985-2009 using the SWB method, were used as the initial MODFLOW input for the 200-year transient stress period simulating long-term mean conditions. Monthly maximum potential evapotranspiration rates estimated using the SWB method were used as initial values for the 75 seasonal stress periods.

The SWB program subtracts evapotranspiration from precipitation as a means of calculating recharge, and in MODLFOW-NWT, evapotranspiration is accounted for as a part of the water budget in the Evapotranspiration package. Evapotranspiration estimated using the SWB method is assumed to originate from plant roots above the water table in the study area, whereas evapotranspiration estimated using MODFLOW-NWT is evapotranspiration from plant roots that extend beneath the water table. Therefore, in areas where the water table is near the land surface, a portion of evapotranspiration may be accounted for twice. To minimize the effect of a double accounting of evapotranspiration, plant rooting depths in the SWB program were assumed to be approximately onehalf the published rooting depths.

Discharge to streams, including river leakage and flow from springs and seeps, was represented with two packages. The River package (Harbaugh, 2005) was used to simulate the hydraulic connection between groundwater and surface water by allowing streams to gain or lose water through streambed material based on the difference between the surrounding hydraulic head and stream stage. The hydraulic conductance of the riverbed material (riverbed conductance) controls the rate at which water can flow from the aquifer to the surface or from the surface into the aquifer. The riverbed conductance was defined by McDonald and Harbaugh (1988) as the hydraulic conductivity multiplied by the cross-sectional area of the stream reach, divided by the streambed thickness. Riverbed conductances were represented as parameters that were adjusted during model calibration (fig. 16). Model cells were represented by the River package for major streams and tributaries in six groups - (1) the Keya Paha River and minor tributaries (KP_RIV), (2) Cottonwood Creek (CTNWD_CR), (3) Buffalo Creek (BUFF_CR), (4) Lost Creek (LOST_CR), (5) Sand Creek (SAND_CR), and (6) Timber Creek (TIMB_ CR) (fig. 16).
The Drain package (Harbaugh, 2005) was used to simulate springs discharging from the Ogallala aquifer along the banks of Keya Paha River, Ponca Creek, and North Fork and South Fork Whetstone Creek, and at the northern edge of the aquifer. The Drain package also was used to simulate leakage from ephemeral stream drainages, including Shadley and Willow Creeks. The Drain package is similar to the River package because drain cells can remove water from the aquifer when the surrounding hydraulic head is above the altitude of the drain within a cell, except that water does not move from the drain cell to the aquifer when the surrounding hydraulic head is lower than the altitude of the drain cell (McDonald and Harbaugh, 1988). Drain conductance is defined the same as riverbed conductance and was determined by model calibration. Drain cells were divided into five spring groups (fig. 16) that include springs and seeps that discharge into (1) the Keya Paha River and tributaries (KEYA_SP), (2) Ponca Creek and tributaries (PONCA_SP), (3) Shadley Creek (SHADLEY_ CR), (4) Willow Creek (WILLOW_CR), and (5) streams at the northern edge of the Ogallala aquifer including North Fork and South Fork Whetstone Creek (DRAIN_1).

Irrigation and public supply withdrawals were simulated with the Well package (Niswonger and others, 2011) to withdraw water from each production well at a specified rate. Some cells represented withdrawal from multiple production wells. The total withdrawal from each production well was aggregated for cells with multiple production wells. Irrigation withdrawals are listed in table 7. Per capita use and maximum and minimum withdrawal rates for public supply are listed in table 8 . All production well locations are shown in figure 13.

\section{Model Calibration}

Model calibration was completed by linking parameter estimation software PEST (Doherty, 2010) with MODFLOWNWT (Niswonger and others, 2011). PEST uses statistical parameter estimation techniques to estimate model parameters, such as aquifer storage properties, spring and river conductance, and hydraulic conductivity. PEST is a modelindependent calibration tool that applies nonlinear estimation techniques and systematically adjusts model parameters and compares model simulated values to observed values of hydraulic head and base flow. PEST attempts to minimize the sum of square weighted differences (residuals) between model simulated and observed values (Doherty, 2010); this sum is referred to as the objective function. Parameter sensitivities and confidence intervals are determined by calculating the derivatives of all observations with respect to all parameters. User-defined ranges for each adjustable parameter can be used to prevent PEST from estimating unrealistic parameter values during the calibration process.

PEST uses regularized inversion (Doherty, 2003, 2010) and can use pilot points for estimation of spatial hydraulic properties. This approach allowed a relatively large number of parameters to be estimated. Classical methods for estimating 


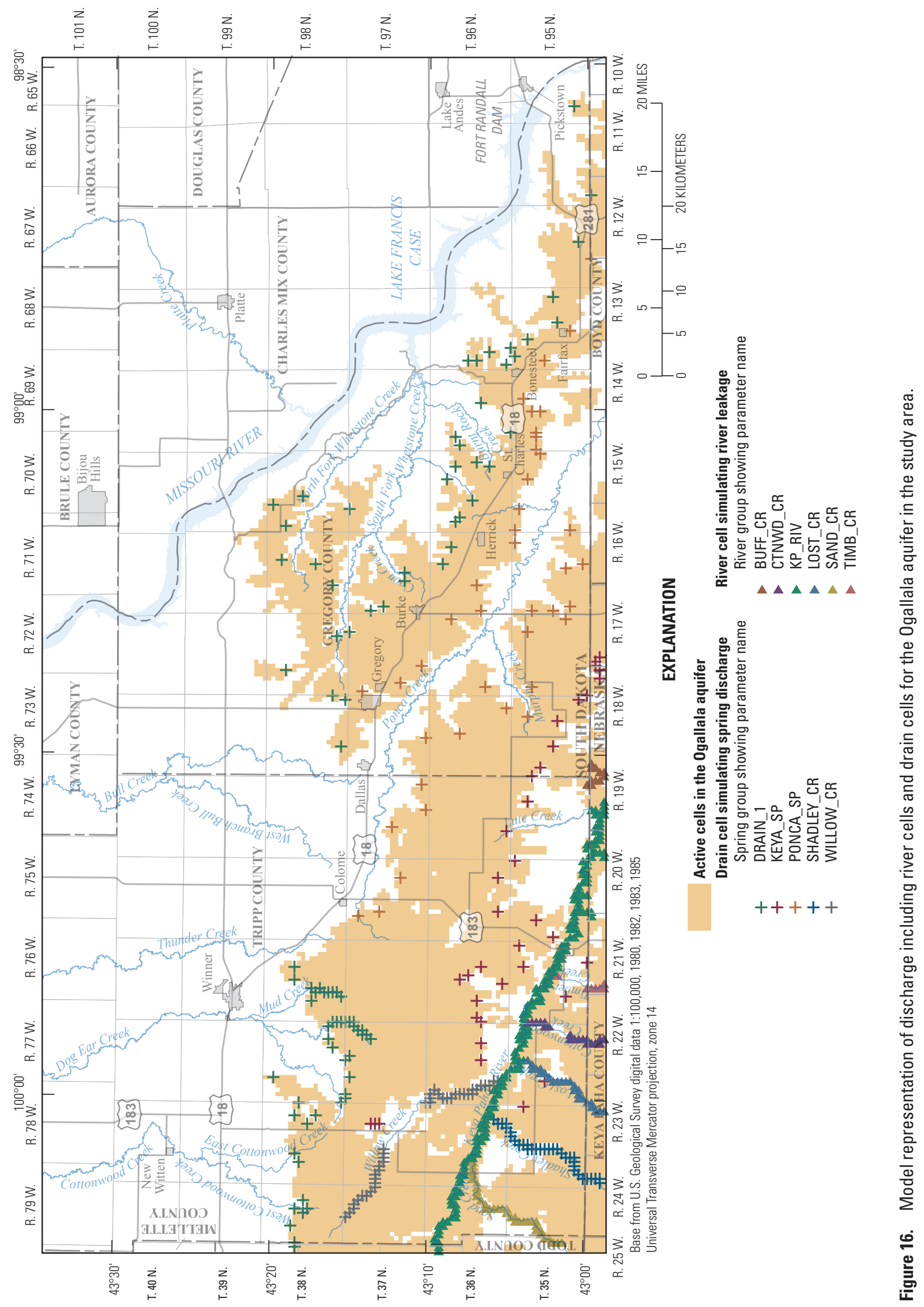


hydraulic conductivity values and distributions within a model include subdividing a model area into zones of piecewise consistency where the hydraulic properties are assumed constant. However, recent studies have shown that interpolating values for a model area on the basis of a set of estimable points (pilot points) distributed throughout the model area can produce a more robust set of input parameter values and output observations (Doherty, 2003).

Pilot points were used as the method of spatial parameterization for the model inputs of hydraulic conductivity, representing the heterogeneity of the aquifer at a scale that was manageable for calibration. Hydraulic conductivity was optimized using PEST and assigned to pilot points distributed throughout the model domain rather than directly to the grid elements of the model (Doherty, 2003; 2010). This method allowed a smooth variation of hydraulic conductivity over the model domain. The values of hydraulic conductivity were estimated for 196 pilot-point locations distributed throughout the model area (fig. 15). Pilot points were spaced closest together in an area south of Winner that coincided with the greatest densities of monitoring wells and production wells. Kriging was used to interpolate hydraulic conductivity for each model cell based on the estimated hydraulic conductivity of the nearest pilot points. Kriging assumes the parameters vary in a continuous manner from one pilot-point location to the next. Thus, points that are near each other have a certain degree of spatial correlation as would be expected given the proximity, but values kriged at points that are widely separated are more independent. PEST uses semivariograms to create relations between neighboring pilot points. A semivariogram was defined by Dunlap and Spinazola (1984) as a "graph of the variability of the difference of the regionalization data versus the distance between points." In other words, a semivariogram is a graph of the amount by which two points differ, plotted against the distance between those points. The kriging factors used in the parameter estimation were created based on usersupplied variograms generated with the PEST groundwater utility programs PPK2FAC and FAC2REAL that are explained in the PEST documentation (Doherty, 2008).

Model cells were separated into two distinct zones, HK1 and HK2 (fig. 15). Zone HK1 contained 169 pilot points, and zone HK2 contained 27 pilot points. The defined hydraulic conductivity range for pilot points was between 1.0 and 180 $\mathrm{ft} / \mathrm{d}$. The anisotropy of the Ogallala aquifer was adjusted by trial and error to produce the best model to measurement fit for measured water levels in observation wells and estimated base flow.

Other parameters optimized during the calibration process included recharge and evapotranspiration multipliers (RCH1_TS and EVT1_TS) and drain and riverbed conductance parameters (DRĀIN_1, KEYA_SP, PONCA_SP, SHADLEY_CR, WILLOW_CR, BUFF_CR, CTNWD_CR, KP_RIV, LOST_CR, SAND_CR, and TIMB_CR).

\section{Calibration Targets}

The 200-year initialization stress period and 75 seasonal stress periods were combined and calibrated as one continuous simulation. The 200-year initialization period was visually calibrated to the estimated mean potentiometric surface for the Ogallala aquifer. Long-term water-level measurements for the 38 State observation wells (fig. 6) that were used to estimate the mean potentiometric surface of the Ogallala aquifer (fig. 7) were considered for calibration of the transient model. Most of the State observation wells (tables 2 and S1-1) are south of Winner in the central part of Tripp County (fig. 6) where multiple production wells exist (fig. 13). The legal locations of State observation wells are listed in tables 2 and S1-1.

Estimated discharge to streams from the Ogallala aquifer, as base flow from springs, seeps, and through riverbed material along the Keya Paha River, also was used during the calibration process. The total groundwater discharge to the Keya Paha River between streamgages at Keyapaha and Wewela was determined using the PART program to estimate base flow as described in the "Discharge to Streams" section of this report. Actual calibration targets for individual spring and river seepage segments were unknown, although the total contribution of all groundwater discharge between the two streamgages was estimated for each stress period. Therefore, trial and error was used to determine the most likely calibration targets for discharge to individual streams from springs, seeps, and hydraulic connection. The total of the calibration targets for each stress period was equal to the estimated base flow for the Keya Paha River for that stress period. Table 9 shows the contribution of individual streams and springs between streamgages at Keyapaha and Wewela for the initialization part of the simulation and the associated river or drain parameter. The total discharge for the Keya Paha River fluctuated seasonally, but it was assumed that the contribution of individual stream and spring components remained constant. Therefore, the contribution of individual stream and spring components fluctuated as a fixed percentage of the total discharge between the two streamgages.

Fewer estimates of base flow were used during the calibration process compared with hydraulic-head measurements. For this reason, simulated discharge to streams through river leakage and from individual springs and seeps was given more weight during the calibration process. Additionally, the relative area of a streambed is greater than the point location of a well within the model. However, the total contribution to the objective function from all simulated discharge was equal to the total contribution to the objective function from simulated hydraulic-head values. Discharge from springs represented by DRAIN_1 and PONCA_SP was not used for calibration because sufficient information was not available; however, the parameters DRAIN_1 and PONCA_SP were optimized for purposes of balancing the simulated water budget. 
Table 9. Estimated discharge components from the Ogallala aquifer as base flow to the Keya Paha River between streamgages at Keyapaha and Wewela, South Dakota, for the for the initialization stress period.

[DRN, parameter used in Drain package of numerical model; RIV, parameter used in River package of numerical model]

\begin{tabular}{|c|c|c|c|c|}
\hline Component & Parameter name & Parameter type & $\begin{array}{c}\text { Discharge rate } \\
\text { (cubic feet per second) }\end{array}$ & $\begin{array}{l}\text { Percentage of total river } \\
\text { and spring discharge }\end{array}$ \\
\hline \multicolumn{5}{|c|}{ Springs } \\
\hline $\begin{array}{l}\text { Multiple springs adjacent to the } \\
\text { Keya Paha River }\end{array}$ & KEYA_SP & DRN & 1.9 & 5.3 \\
\hline \multicolumn{5}{|c|}{ Seeps and hydraulic connection } \\
\hline Keya Paha River & KP_RIV & RIV & 3.9 & 10.8 \\
\hline Willow Creek & WILLOW_CR & DRN & 4.3 & 11.9 \\
\hline Sand Creek & SAND_CR & RIV & 2.8 & 7.9 \\
\hline Shadley Creek & SHADLEY_CR & DRN & 2.8 & 7.9 \\
\hline Lost Creek & LOST_CR & RIV & 11.3 & 31.7 \\
\hline Cottonwood Creek & CTNWD_CR & RIV & 4.9 & 13.8 \\
\hline Timber Creek & TIMB_CR & RIV & 3.8 & 10.6 \\
\hline Total & & & $35.7^{\mathrm{a}}$ & $99.9^{b}$ \\
\hline
\end{tabular}

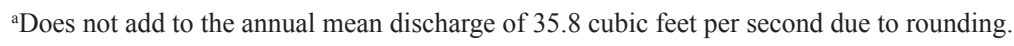

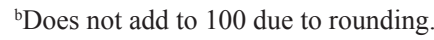

Table 10. Calibrated horizontal hydraulic conductivity for pilot points used in numerical model.

[Hydraulic conductivity values are in feet per day. The locations of the pilot points and hydraulic conductivity zones are shown in figure 15]

\begin{tabular}{cccccc}
\hline $\begin{array}{c}\text { Parameter } \\
\text { group name }\end{array}$ & $\begin{array}{c}\text { Number of } \\
\text { pilot points }\end{array}$ & Mean sensitivity & $\begin{array}{c}\text { Minimum } \\
\text { parameter value }\end{array}$ & $\begin{array}{c}\text { Mean } \\
\text { parameter value }\end{array}$ & $\begin{array}{c}\text { Maximum } \\
\text { parameter value }\end{array}$ \\
\hline HK1 & 169 & 0.0534 & 1.0 & 71.2 & 180 \\
HK2 & 27 & 0.0512 & 6.4 & 26.1 & 111 \\
\hline
\end{tabular}

\section{Calibrated Parameter Values}

Calibrated values were determined for hydraulic conductivity, riverbed and drain conductance, and recharge and maximum potential evapotranspiration rates based on the recharge and evapotranspiration multipliers (tables 10 and 11). Calibrated hydraulic conductivity ranged from 1.0 to $180 \mathrm{ft} / \mathrm{d}$, with a mean of $71.2 \mathrm{ft} / \mathrm{d}$ for pilot points in hydraulic conductivity group HK1 and from 6.4 to $111 \mathrm{ft} / \mathrm{d}$, with a mean of $26.1 \mathrm{ft} / \mathrm{d}$ for pilot points in hydraulic conductivity group HK2 (table 10). Hydraulic conductivity interpolated to model cells from pilot-point values ranged from 0.9 to $227 \mathrm{ft} / \mathrm{d}$ (fig. 17). Actual values interpolated to each cell were higher and lower than the predefined parameter limits for pilot points and were a result of the method used to interpolate values to each model cell. Riverbed and drain conductance ranged from $2.9 \times 10^{2}$ to $1.3 \times 10^{4} \mathrm{ft}^{2} / \mathrm{d}$ (table 11 ). High drain conductance was associated with drain parameter DRAIN_1, and high riverbed conductance was associated with river parameter CTNWD_CR. The calibrated recharge multiplier was 1.2, and the calibrated maximum potential evapotranspiration multiplier was 1.2. Fixed values for storage coefficient and specific yield were used. Storage coefficient was 0.004 , and specific yield was 0.13 .

For zone HK1, a horizontal anisotropy magnitude of 2 was applied in a direction south 65 degrees east. For zone HK2, a horizontal anisotropy magnitude of 2 was applied in a direction south 60 degrees east. This anisotropy produced the most reasonable hydraulic conductivity distribution throughout the model domain, based on the spatial interpolation of pilot-point values to model cells (fig. 17). The orientation of the anisotropy was determined to be consistent with the general orientation of major streams within the study area; thus, it is possible that the anisotropy orientation is a result of structural control within the aquifer. Additionally, the general direction of groundwater flow in the study area likely supports this anisotropy orientation.

PEST calculated the 95-percent confidence intervals on parameters, which indicates 95 -percent confidence that a parameter value within the confidence interval results in the best fit between model simulated and observed values (table 11). Confidence intervals are an indicator of parameter uncertainty, and they rely on a linearity assumption. For parameters with large confidence intervals, the linearity assumption may 
Table 11. Calibrated parameters for the numerical model.

[ft²/d, square feet per day; --, not applicable]

\begin{tabular}{|c|c|c|c|}
\hline \multirow{2}{*}{ Parameter name } & \multirow{2}{*}{ Estimated parameter value } & \multicolumn{2}{|c|}{ 95-percent confidence intervals } \\
\hline & & Lower limit & Upper limit \\
\hline \multicolumn{4}{|c|}{ Vertical hydraulic conductivity (fraction of horizontal hydraulic conductivity) } \\
\hline VKA1_1 & 0.1 & -- & -- \\
\hline \multicolumn{4}{|c|}{ Specific yield (dimensionless) } \\
\hline SY1_1 & 0.13 & -- & -- \\
\hline \multicolumn{4}{|c|}{ Storage coefficient (dimensionless) } \\
\hline $\mathrm{SC} 1 \_1$ & 0.004 & -- & -- \\
\hline \multicolumn{4}{|c|}{$\begin{array}{l}\text { Vertical conductance of sediments separating ephemeral streams and springs and the Ogallala aquife } \\
\qquad\left(\mathrm{ft}^{2} / \mathrm{d} \text {; see figure } 16 \text { for location of stream reach) }\right.\end{array}$} \\
\hline DRAIN_1 & $1.30 \times 10^{4}$ & $2.59 \times 10^{3}$ & $6.50 \times 10^{4}$ \\
\hline KEYA_SP & $9.69 \times 10^{2}$ & $4.48 \times 10^{2}$ & $2.09 \times 10^{3}$ \\
\hline PONCA_SP & $1.16 \times 10^{4}$ & $4.61 \times 10^{-6}$ & $2.92 \times 10^{13}$ \\
\hline SHADLEY_CR & $6.90 \times 10^{2}$ & $3.55 \times 10^{2}$ & $1.34 \times 10^{3}$ \\
\hline WILLOW_CR & $3.64 \times 10^{3}$ & $2.30 \times 10^{3}$ & $5.75 \times 10^{3}$ \\
\hline \multicolumn{4}{|c|}{$\begin{array}{l}\text { Vertical conductance of sediments separating perennial streams and the Ogallala aquifer } \\
\qquad\left(\mathrm{ft}^{2} / \mathrm{d} \text {; see figure } 16 \text { for location of stream reach) }\right.\end{array}$} \\
\hline KP_RIV & $2.90 \times 10^{2}$ & $1.64 \times 10^{2}$ & $5.15 \times 10^{2}$ \\
\hline BUFF_CR & $6.93 \times 10^{3}$ & $4.37 \times 10^{-7}$ & $1.10 \times 10^{14}$ \\
\hline CTNWD_CR & $1.07 \times 10^{4}$ & $3.04 \times 10^{3}$ & $3.77 \times 10^{4}$ \\
\hline LOST_CR & $1.04 \times 10^{4}$ & $4.65 \times 10^{3}$ & $2.31 \times 10^{4}$ \\
\hline SAND_CR & $6.44 \times 10^{2}$ & $1.70 \times 10^{2}$ & $2.44 \times 10^{3}$ \\
\hline TIMB_CR & $5.28 \times 10^{3}$ & $1.05 \times 10^{2}$ & $2.66 \times 10^{5}$ \\
\hline \multicolumn{4}{|c|}{ Recharge multiplier } \\
\hline RCH1_TS & 1.2 & 1.07 & 1.33 \\
\hline \multicolumn{4}{|c|}{ Evapotranspiration multiplier } \\
\hline EVT1_TS & 1.2 & 0.96 & 1.44 \\
\hline
\end{tabular}

not be valid. The largest confidence intervals are associated with parameters BUFF_CR, PONCA_SP, CTNWD_CR, and TIMB_CR. Other parameters, for example RCH1_TS and EVT1_TS, had small confidence intervals, indicating a high degree of confidence in these estimates relative to other parameters. Parameters RCH1_TS and EVT1_TS were optimized to their predefined upper limit, which likely had an effect on the small confidence limits associated with those parameters.

\section{Sensitivity Analysis}

The model's ability to estimate a parameter value during calibration is related to the sensitivity of the changes in the model output relative to changes in the parameter value. The relative composite sensitivity of a model parameter is a measure of the composite changes in model outputs that are incurred by a small change in the value of the parameter
(Doherty, 2010). The model is most sensitive to parameters associated with a high relative composite sensitivity and least sensitive to parameters associated with a low relative composite sensitivity. PEST calculated the relative composite sensitivity for each adjustable model parameter (fig. 18). Relative composite sensitivities for hydraulic conductivity groups HK1 and HK2 represent the mean relative composite sensitivity of all pilot points within their associated group. Model outputs were most sensitive to changes in the multiplier parameter RCH1_TS, which is associated with recharge to the model. Model outputs also were highly sensitive to changes in the evapotranspiration multiplier EVT1_TS and drain conductance parameter DRAIN_1. The model was least sensitive to drain and riverbed conductance parameters PONCA_SP and BUFF_CR. 


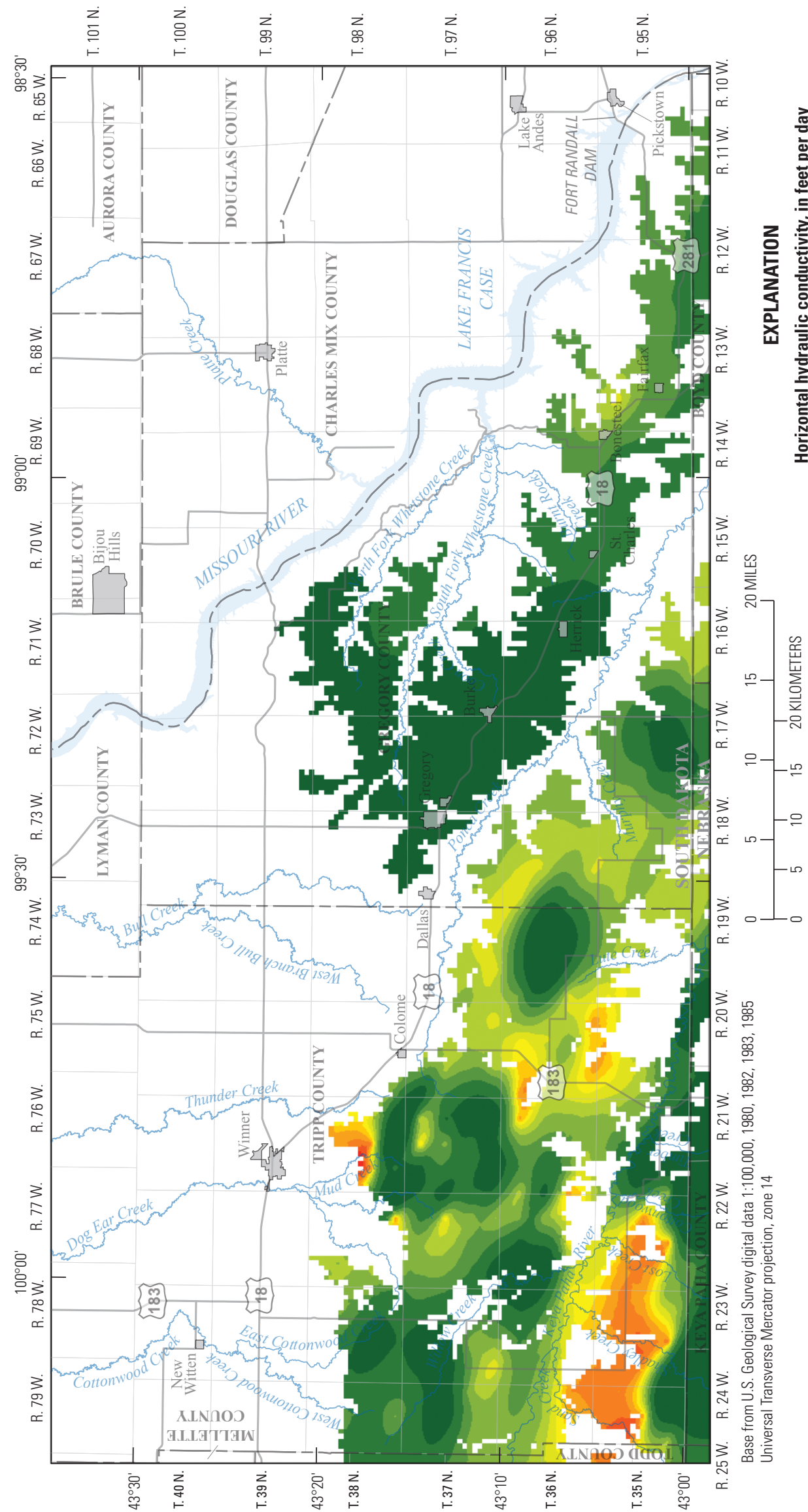

응 ๑ ㅇำ సิ

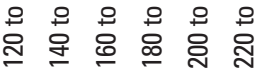

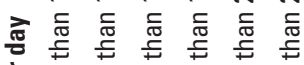

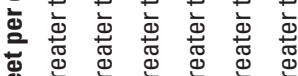

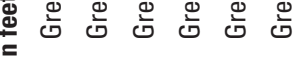

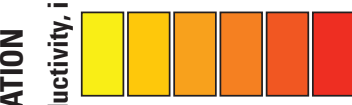

웅 80 응

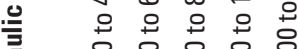

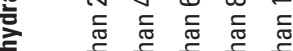

ก

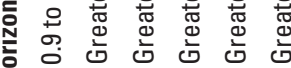

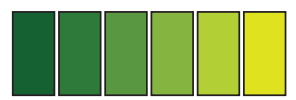

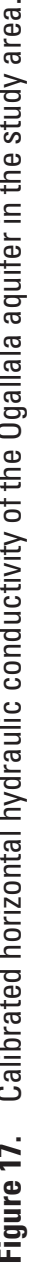




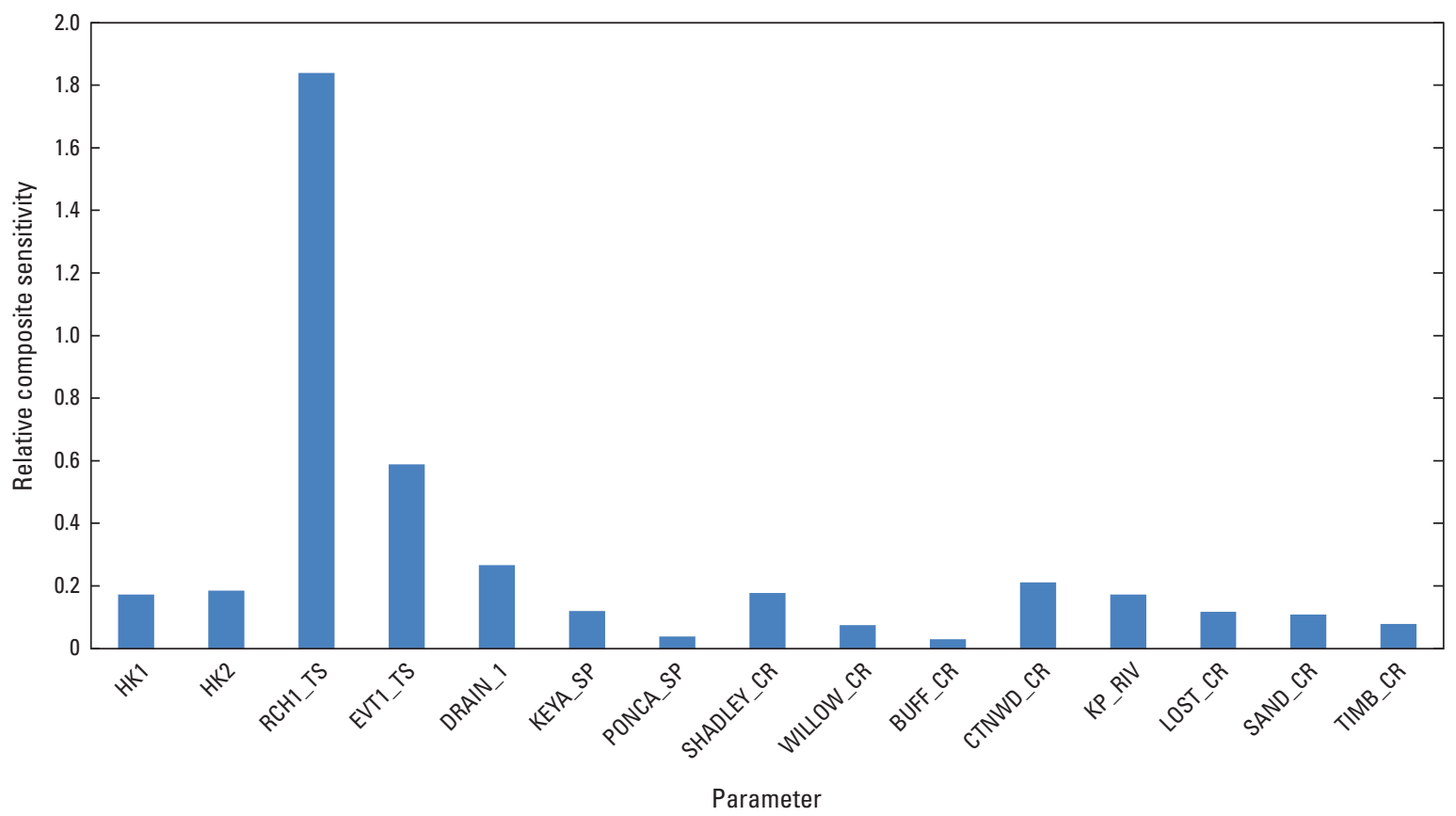

Figure 18. Relative composite parameter sensitivities, as defined by Doherty (2010), for the numerical model.

\section{Simulation of Groundwater Flow}

The numerical model was used to simulate transient conditions for the 25-year period (WYs 1985-2009) previously described. The calibration objective for the 200 -year initialization period was to simulate the observed potentiometric surface and balance inflows and outflows for the aquifer. The calibration objective for the 25 -year transient part of the simulation was to reproduce long-term water-level measurements for 38 State observation wells and estimated base flow for the Keya Paha River.

\section{Initialization Period}

The primary objective of model calibration was to minimize the objective function. A secondary objective of model calibration was that the simulated potentiometric surface and hydraulic gradients for the initialization period generally match those of the observed mean potentiometric surface. The simulated potentiometric surface from the 200-year initialization period (fig. 19) generally was similar to the observed potentiometric surface (fig. 7) based on hydraulic heads and gradients, indicating a satisfaction of this objective. For all active model cells, the simulated potentiometric surface was within $\pm 35 \mathrm{ft}$ of the observed potentiometric surface for 96 percent of all active model cells (fig. 20). The difference between the observed and simulated potentiometric surfaces ranged from +85 to $-72 \mathrm{ft}$. Generally, the maximum differences between the observed and simulated potentiometric surfaces were associated with areas near the edge of the model. The simulated potentiometric surface generally had lower hydraulic heads than did the observed potentiometric surface, which is indicated by the mean difference of $+3.3 \mathrm{ft}$ (observed minus simulated hydraulic heads) for all model cells. The standard deviation of differences between the observed and simulated potentiometric surfaces for all cells was $15.3 \mathrm{ft}$, and the variance was 236 square feet $\left(\mathrm{ft}^{2}\right)$. The standard deviation and variance (Helsel and Hirsch, 1992) are used as general indicators of the accuracy of the model to measurement fit.

The numerical solution for the water budget for the initialization part of the simulation was balanced (inflows minus outflows) with a percentage discrepancy of 0.00 (table 12). Simulated recharge was 18 percent greater than the recharge estimated using the SWB method for the initialization period. This represents a total simulated recharge rate of $281.2 \mathrm{ft}^{3} / \mathrm{s}$ for the initialization period. Model-calculated maximum potential evapotranspiration was 20 percent greater than the SWB-estimated maximum potential evapotranspiration for this period. As a result of the maximum potential evapotranspiration multiplier, the total evapotranspiration rate was $225.6 \mathrm{ft}^{3} / \mathrm{s}$ for the initialization period. The simulated river leakage from the aquifer to the Keya Paha River of $30.5 \mathrm{ft}^{3} / \mathrm{s}$ calculated by the numerical model for the initialization period was within $6.0 \mathrm{ft}^{3} / \mathrm{s}$ of estimated base flow for the conceptual model.

\section{Transient Simulation}

The primary calibration objective was to minimize the objective function. The first objective as a part of the calibration process was to minimize the difference between simulated transient water-level altitudes (hydraulic heads) and observed hydraulic heads for the 38 State observation wells for WYs 1985-2009. The model was calibrated to 6,191 water-level measurements for the 38 State observation wells so that 

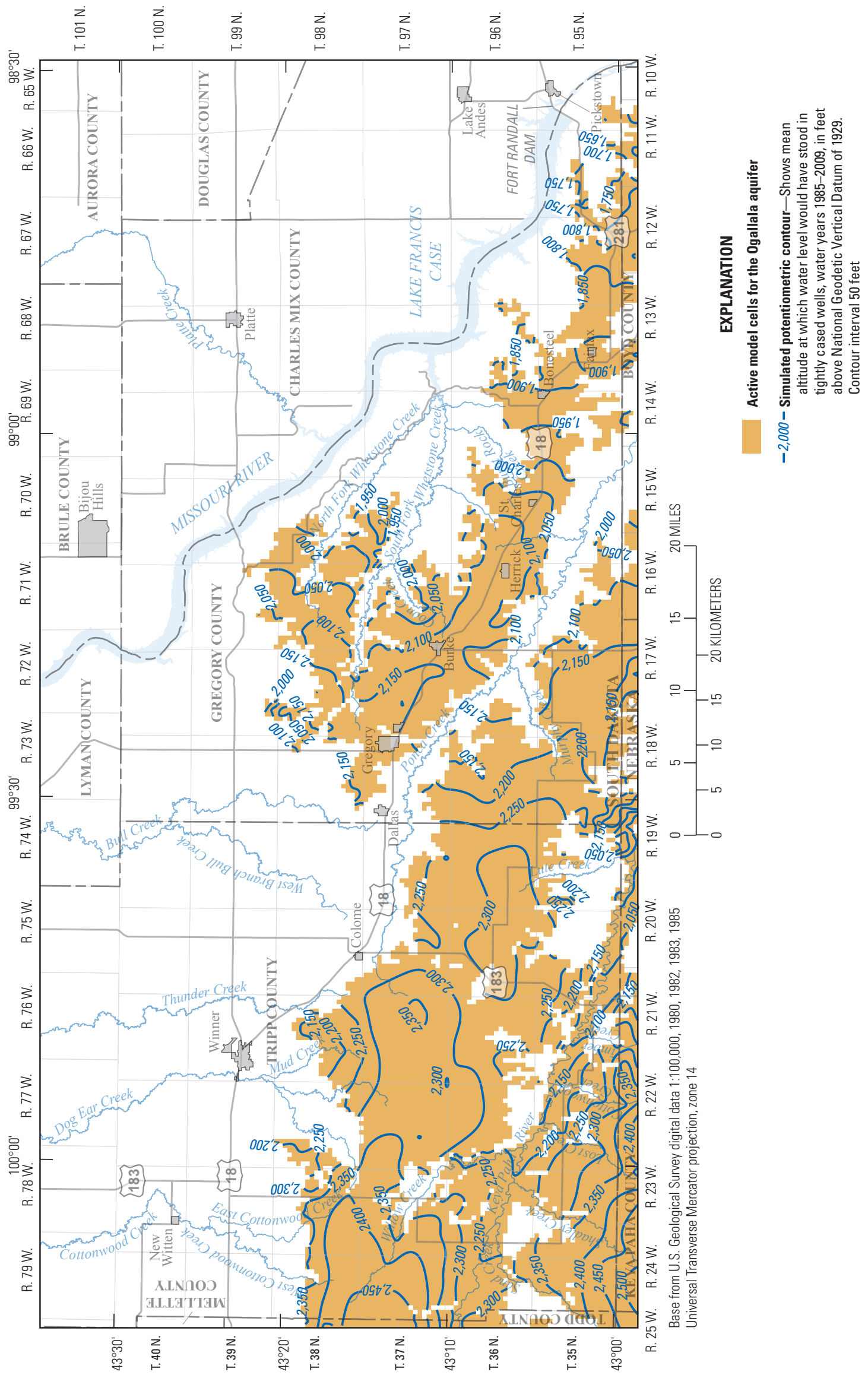

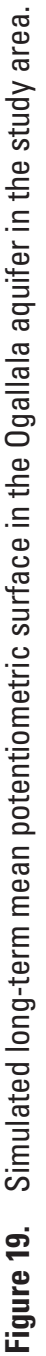




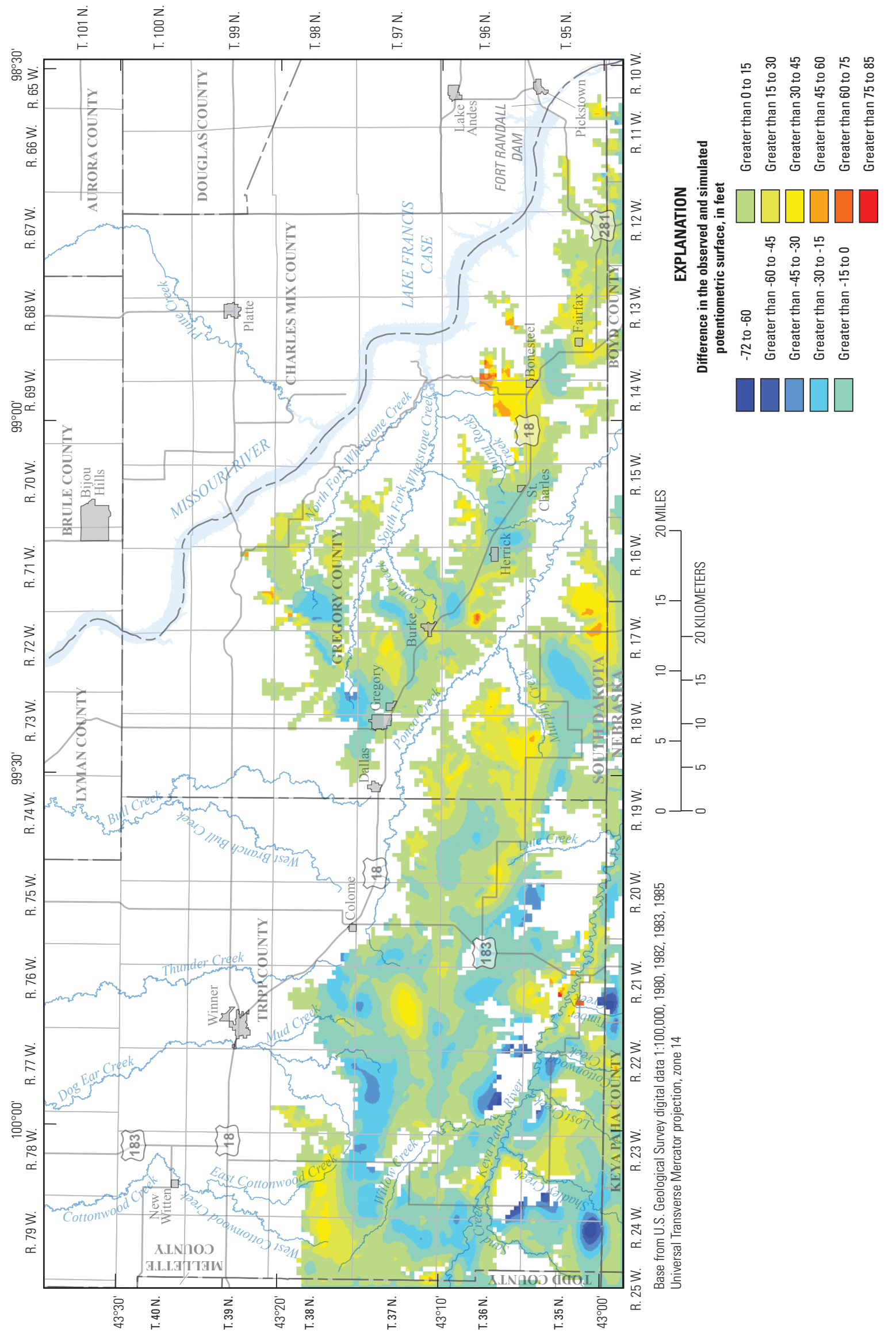


Table 12. Water budget for the numerical model simulating long-term mean conditions compared with flow estimates from the conceptual model.

$\left[\mathrm{ft} \mathrm{s}^{3} \mathrm{~s}\right.$, cubic feet per second; --, not estimated or not applicable]

\begin{tabular}{|c|c|c|}
\hline \multirow{2}{*}{ Flow component } & \multicolumn{2}{|c|}{$\begin{array}{c}\text { Flow rate } \\
\left(\mathrm{ft}^{3} / \mathrm{s}\right)\end{array}$} \\
\hline & $\begin{array}{c}\text { Numerical } \\
\text { model }\end{array}$ & $\begin{array}{c}\text { Conceptual } \\
\text { model }\end{array}$ \\
\hline \multicolumn{3}{|c|}{ Inflows } \\
\hline Storage & 0.0016 & -- \\
\hline Constant-head boundaries & 18.6 & -- \\
\hline River leakage & 0.7 & -- \\
\hline Recharge & 281.2 & 239 \\
\hline Total inflows & 300.5 & -- \\
\hline
\end{tabular}

\begin{tabular}{lcl}
\hline \multicolumn{2}{c}{ Outflows } & \\
\hline Storage & 0.0016 & -- \\
Constant-head boundaries & 7.0 & -- \\
Well withdrawals & 5.5 & 5.48 \\
Springs along Ponca Creek & 8.3 & 3.85 \\
Other springs and seeps & 19.5 & -- \\
Keya Paha River ${ }^{\mathrm{a}}$ & 30.5 & 35.8 \\
Other river leakage & 4.1 & -- \\
Evapotranspiration & 225.6 & -- \\
$\quad$ Total outflows & 300.5 & -- \\
\hline Inflows minus outflows & 0.00 & -- \\
Percent discrepancy & 0.00 & -- \\
\hline
\end{tabular}

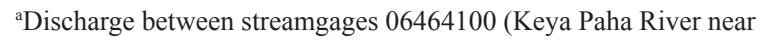
Keyapaha) and 06464500 (Keya Paha River at Wewela). Includes springflow along river banks.

mean simulated hydraulic heads for 95 percent of wells were within $\pm 20 \mathrm{ft}$ of the observed hydraulic heads. This calibration criterion was met by calibrating the model using PEST as described in the "Model Calibration" section of this report.

Basic statistics were calculated for comparison of observed and simulated hydraulic heads for State observation wells (table 13). Comparisons of the mean, standard deviation, and variance for observed and simulated hydraulic heads were used as general indicators of the accuracy of model to measurement fit. Mean simulated water levels matched observed values within $\pm 20 \mathrm{ft}$ for 95 percent and to within $\pm 10 \mathrm{ft}$ for 84 percent of State observation wells, with a mean difference of $-1.6 \mathrm{ft}$ (observed minus simulated) and a mean absolute difference of $5.1 \mathrm{ft}$. For the State observation wells, mean differences between observed and simulated hydraulic heads were within $22 \mathrm{ft}$. Large discrepancies between observed and simulated hydraulic heads generally were associated with observation wells near specified-head boundaries or where observation wells were near production wells that were closely spaced (fig. 21). The model overestimated mean hydraulic heads for 21 of the State observation wells and underestimated mean hydraulic heads for 15 of the State observation wells. The mean of the difference between observed and simulated means was $-1.6 \mathrm{ft}$ (table 13).

A histogram shows the distribution of the difference between the observed and simulated hydraulic heads (residuals) for all 6,191 measurements from the State observation wells (fig. 22). Simulated hydraulic heads ranged from +41.6 to $-50.0 \mathrm{ft}$ of observed hydraulic heads. Hydrographs for State observation wells for the 25-year transient part of the simulation are shown in figure 23 , which shows that the general trends in simulated and observed hydraulic heads matched reasonably well. Analysis of the data indicates a model bias of overestimating hydraulic heads. For all water-level measurements for State observation wells, the model overestimated 56.5 percent of hydraulic heads and underestimated 43.5 percent of hydraulic heads. A linear regression analysis between simulated and observed hydraulic heads for State observation wells yielded an $\mathrm{R}^{2}$ value (coefficient of determination; fraction of the variance explained by regression) of 1.00 (fig. 24).

The second objective as a part of the calibration process was to minimize the difference between model-simulated base flow and PART-estimated base flow. Base flow is sensitive to many model components besides riverbed conductance. The simulated base flow from groundwater discharge had less seasonal variability between stress periods than the base flow (fig. 25) estimated using PART as described in the "Discharge to Streams" section of this report. In general, base flow was overestimated by the model and within 42 percent of the mean estimated values for the Keya Paha River (fig. 25; table 14). This discrepancy could represent limitations in estimates of base flow, the ability of the model to simulate base flow, or both. Simulated base flow for the Keya Paha River ranged from 25.5 to $39.0 \mathrm{ft}^{3} / \mathrm{s}$.

Simulated rates of recharge for the transient stress periods, applying the calibrated recharge multiplier, ranged from 0.60 to $6.96 \mathrm{in} / \mathrm{yr}$, with a mean of $3.68 \mathrm{in} / \mathrm{yr}$ for the Ogallala aquifer. This represents a mean total recharge rate of $280.5 \mathrm{ft}^{3} / \mathrm{s}$ for the numerical model. Transient simulated annual evapotranspiration rates, applying the calibrated evapotranspiration multiplier, ranged from 128.1 to $253.6 \mathrm{ft}^{3} / \mathrm{s}$, with a mean annual evapotranspiration rate of about $185 \mathrm{ft}^{3} / \mathrm{s}$. Simulated net discharge rate to streams through river leakage and flow from springs and seeps ranged from 52.2 to $79.9 \mathrm{ft}^{3} / \mathrm{s}$, with a mean annual rate of $66.7 \mathrm{ft}^{3} / \mathrm{s}$. Reported irrigation well withdrawals (table 7) and estimated public supply withdrawals (table 8 ) were used in the numerical model and had a combined annual rate of $5.48 \mathrm{ft}^{3} / \mathrm{s}$.

\section{Simulation of Future Scenarios}

Using the input parameters determined during model calibration, simulations were conducted to estimate groundwater responses to hypothetical potential future scenarios of drought and increases in well withdrawals. A synthetic drought record was created that used the spatial and temporal variations in 
Table 13. Comparison of observed and simulated hydraulic heads for State observation wells for the transient simulation.

[NGVD 29, National Geodetic Vertical Datum of 1929; --, not applicable]

\begin{tabular}{|c|c|c|c|c|c|c|c|c|c|}
\hline $\begin{array}{l}\text { State observa- } \\
\text { tion well } \\
\text { (index number } \\
\text { on figure 21) }\end{array}$ & Data type & $\begin{array}{c}\text { Mean } \\
\text { hydraulic } \\
\text { head } \\
\text { (feet above } \\
\text { NGVD 29) }\end{array}$ & $\begin{array}{c}\text { Standard } \\
\text { deviation } \\
\text { (feet) }\end{array}$ & $\begin{array}{c}\text { Variance } \\
\text { (feet } \\
\text { squared) }\end{array}$ & $\begin{array}{c}\text { Range } \\
\text { (feet) }\end{array}$ & $\begin{array}{l}\text { Minimum } \\
\text { hydraulic } \\
\text { head } \\
\text { (feet above } \\
\text { NGVD 29) }\end{array}$ & $\begin{array}{l}\text { Maximum } \\
\text { hydraulic } \\
\text { head } \\
\text { (feet above } \\
\text { NGVD 29) }\end{array}$ & $\begin{array}{l}\text { Difference be- } \\
\text { tween observed } \\
\text { and simulated } \\
\text { means } \\
\text { (feet) }\end{array}$ & $\begin{array}{c}\text { Mean of } \\
\text { absolute } \\
\text { values of } \\
\text { residuals } \\
\text { (feet) }\end{array}$ \\
\hline \multirow[t]{2}{*}{ GY-57A (74) } & Observed & $2,138.5$ & 3.38 & 11.40 & 16.8 & $2,127.2$ & $2,144.0$ & & \\
\hline & Simulated & $2,137.2$ & 1.14 & 1.30 & 4.8 & $2,134.7$ & $2,139.5$ & 1.3 & 2.6 \\
\hline GY-57B (68) & Simulated & $2,081.1$ & 1.05 & 1.10 & 4.3 & $2,078.9$ & $2,083.2$ & -1.2 & 1.4 \\
\hline \multirow[t]{2}{*}{ GY-77A (126) } & Observed & $2,145.2$ & 1.01 & 1.03 & 4.8 & $2,142.8$ & $2,147.6$ & & \\
\hline & Simulated & $2,140.8$ & 0.72 & 0.52 & 3.3 & $2,139.2$ & $2,142.5$ & 4.5 & 4.5 \\
\hline \multirow[t]{2}{*}{ GY-77B (132) } & Observed & $2,152.9$ & 1.69 & 2.84 & 7.8 & $2,150.0$ & $2,157.8$ & & \\
\hline & Simulated & $2,151.4$ & 1.30 & 1.69 & 5.2 & $2,148.8$ & $2,154.0$ & 1.5 & 1.7 \\
\hline $\mathrm{GY}-78 \mathrm{~B}(22)$ & Simulated & $2,182.8$ & 1.73 & 3.00 & 7.4 & $2,178.8$ & $2,186.3$ & 0.0 & 1.7 \\
\hline \multirow[t]{2}{*}{ GY-78C (13) } & Observed & $1,897.7$ & 3.52 & 12.42 & 12.5 & $1,892.8$ & $1,905.3$ & & \\
\hline & Simulated & $1,899.8$ & 1.02 & 1.05 & 4.1 & $1,897.7$ & $1,901.8$ & -2.1 & 3.1 \\
\hline \multirow[t]{2}{*}{ GY-78D (18) } & Observed & $1,909.7$ & 2.24 & 5.00 & 8.2 & $1,906.6$ & $1,914.8$ & & \\
\hline & Simulated & $1,910.6$ & 0.98 & 0.96 & 4.0 & $1,908.6$ & $1,912.6$ & -0.9 & 1.6 \\
\hline \multirow[t]{2}{*}{ TR-57C (29) } & Observed & $1,963.1$ & 0.75 & 0.56 & 3.4 & $1,961.8$ & $1,965.2$ & & \\
\hline & Simulated & $1,985.4$ & 1.58 & 2.48 & 6.6 & $1,982.9$ & $1,989.5$ & -22.3 & 22.3 \\
\hline TR-59B (48) & Observed & $2,342.3$ & 1.57 & 2.46 & 6.6 & 2,339.9 & $2,346.5$ & & \\
\hline $\mathrm{TR}-72 \mathrm{C}(235)$ & Simulated & $2,212.6$ & 2.13 & 4.55 & 8.8 & $2,208.1$ & $2,216.8$ & 3.8 & 4.0 \\
\hline \multirow[t]{2}{*}{ TR-72D (243) } & Observed & $2,221.8$ & 2.40 & 5.78 & 11.5 & $2,215.4$ & $2,226.9$ & & \\
\hline & Simulated & $2,224.7$ & 2.01 & 4.02 & 8.3 & $2,220.7$ & $2,229.0$ & -3.0 & 3.1 \\
\hline \multirow[t]{2}{*}{ TR-72E (159) } & Observed & $2,257.3$ & 1.91 & 3.64 & 9.8 & $2,252.7$ & $2,262.5$ & & \\
\hline & Simulated & $2,260.3$ & 1.61 & 2.58 & 6.9 & $2,257.0$ & $2,263.9$ & -3.0 & 3.0 \\
\hline \multirow[t]{2}{*}{ TR-72F (237) } & Observed & $2,238.3$ & 6.20 & 38.43 & 22.3 & $2,227.7$ & $2,250.0$ & & \\
\hline & Simulated & $2,242.2$ & 1.65 & 2.71 & 7.1 & $2,239.0$ & $2,246.1$ & -3.8 & 4.9 \\
\hline \multirow[t]{2}{*}{ TR-72G (238) } & Observed & $2,231.2$ & 17.86 & 318.85 & 50.7 & $2,201.6$ & $2,252.3$ & & \\
\hline & Simulated & $2,236.0$ & 2.53 & 6.41 & 10.6 & $2,231.0$ & $2,241.6$ & -4.8 & 13.9 \\
\hline \multirow[t]{2}{*}{ TR-72H (239) } & Observed & $2,225.3$ & 10.03 & 100.63 & 35.9 & $2,202.6$ & $2,238.5$ & & \\
\hline & Simulated & $2,242.7$ & 1.46 & 2.13 & 6.3 & $2,239.8$ & $2,246.2$ & -17.3 & 17.3 \\
\hline \multirow[t]{2}{*}{ TR-74A (236) } & Observed & $2,248.8$ & 2.72 & 7.41 & 12.5 & $2,242.3$ & $2,254.8$ & & \\
\hline & Simulated & $2,242.7$ & 2.42 & 5.87 & 10.1 & $2,237.8$ & $2,247.9$ & 6.1 & 6.1 \\
\hline \multirow[t]{2}{*}{ TR-74D (242) } & Observed & $2,258.2$ & 1.80 & 3.22 & 9.4 & $2,253.4$ & $2,262.8$ & & \\
\hline & Simulated & $2,255.2$ & 1.66 & 2.76 & 7.2 & $2,251.6$ & $2,258.8$ & 3.0 & 3.0 \\
\hline
\end{tabular}


Table 13. Comparison of observed and simulated hydraulic heads for State observation wells for the transient simulation.-Continued [NGVD 29, National Geodetic Vertical Datum of 1929; --, not applicable]

\begin{tabular}{|c|c|c|c|c|c|c|c|c|c|}
\hline $\begin{array}{l}\text { State observa- } \\
\text { tion well } \\
\text { (index number } \\
\text { on figure 21) }\end{array}$ & Data type & $\begin{array}{c}\text { Mean } \\
\text { hydraulic } \\
\text { head } \\
\text { (feet above } \\
\text { NGVD 29) }\end{array}$ & $\begin{array}{c}\text { Standard } \\
\text { deviation } \\
\text { (feet) }\end{array}$ & $\begin{array}{c}\text { Variance } \\
\text { (feet } \\
\text { squared) }\end{array}$ & $\begin{array}{l}\text { Range } \\
\text { (feet) }\end{array}$ & $\begin{array}{l}\text { Minimum } \\
\text { hydraulic } \\
\text { head } \\
\text { (feet above } \\
\text { NGVD 29) }\end{array}$ & $\begin{array}{l}\text { Maximum } \\
\text { hydraulic } \\
\text { head } \\
\text { (feet above } \\
\text { NGVD 29) }\end{array}$ & $\begin{array}{l}\text { Difference be- } \\
\text { tween observed } \\
\text { and simulated } \\
\text { means } \\
\text { (feet) }\end{array}$ & $\begin{array}{l}\text { Mean of } \\
\text { absolute } \\
\text { values of } \\
\text { residuals } \\
\text { (feet) }\end{array}$ \\
\hline \multirow[t]{2}{*}{ TR-74E (241) } & Observed & $2,253.4$ & 1.75 & 3.06 & 7.9 & $2,250.0$ & $2,257.9$ & & \\
\hline & Simulated & $2,254.0$ & 1.73 & 3.00 & 7.4 & $2,250.4$ & $2,257.8$ & -0.5 & 1.0 \\
\hline \multirow[t]{2}{*}{ TR-74F (240) } & Observed & $2,257.1$ & 1.82 & 3.31 & 8.4 & $2,253.7$ & $2,262.1$ & & \\
\hline & Simulated & $2,251.5$ & 1.95 & 3.80 & 8.1 & $2,247.7$ & $2,255.8$ & 5.6 & 5.6 \\
\hline \multirow[t]{2}{*}{ TR-75B (244) } & Observed & $2,223.3$ & 2.06 & 4.25 & 8.6 & $2,218.8$ & $2,227.4$ & & \\
\hline & Simulated & $2,219.0$ & 1.72 & 2.95 & 7.8 & $2,215.5$ & $2,223.3$ & 4.3 & 4.3 \\
\hline \multirow[t]{2}{*}{ TR-78A (169) } & Observed & $2,323.1$ & 2.18 & 4.73 & 6.7 & $2,320.4$ & $2,327.1$ & & \\
\hline & Simulated & $2,324.6$ & 2.47 & 6.10 & 9.8 & $2,319.5$ & $2,329.4$ & -1.6 & 2.7 \\
\hline \multirow[t]{2}{*}{ TR-78B (181) } & Observed & $2,342.8$ & 2.00 & 4.01 & 7.6 & $2,338.8$ & $2,346.4$ & & \\
\hline & Simulated & $2,341.4$ & 1.76 & 3.08 & 6.9 & $2,337.9$ & $2,344.8$ & 1.3 & 2.1 \\
\hline \multirow[t]{2}{*}{ TR-78C (209) } & Observed & $2,335.7$ & 1.59 & 2.53 & 6.2 & $2,333.0$ & $2,339.2$ & & \\
\hline & Simulated & $2,336.1$ & 2.01 & 4.05 & 9.3 & $2,332.2$ & $2,341.5$ & -0.4 & 1.2 \\
\hline \multirow[t]{2}{*}{ TR-78D (249) } & Observed & $2,416.7$ & 1.63 & 2.66 & 6.5 & $2,414.0$ & $2,420.5$ & & \\
\hline & Simulated & $2,416.7$ & 1.59 & 2.52 & 6.4 & $2,413.5$ & $2,419.9$ & 0.0 & 1.6 \\
\hline \multirow[t]{2}{*}{ TR-78E (51) } & Observed & $2,388.3$ & 1.82 & 3.33 & 8.0 & $2,384.2$ & $2,392.2$ & & \\
\hline & Simulated & $2,392.3$ & 2.54 & 6.43 & 10.6 & $2,387.1$ & $2,397.7$ & -4.0 & 4.0 \\
\hline \multirow[t]{2}{*}{ TR-78F (35) } & Observed & $2,222.4$ & 1.47 & 2.16 & 5.5 & $2,219.6$ & $2,225.1$ & & \\
\hline & Simulated & $2,222.2$ & 1.45 & 2.09 & 6.1 & $2,219.1$ & $2,225.2$ & 0.3 & 0.8 \\
\hline \multirow[t]{2}{*}{ TR-78G (157) } & Observed & $2,323.3$ & 2.16 & 4.65 & 9.1 & $2,319.0$ & $2,328.1$ & & \\
\hline & Simulated & $2,323.0$ & 2.07 & 4.28 & 8.2 & $2,319.3$ & $2,327.4$ & 0.3 & 1.1 \\
\hline \multirow[t]{2}{*}{ TR-78H (167) } & Observed & $2,327.4$ & 1.52 & 2.30 & 6.5 & $2,324.4$ & $2,330.9$ & & \\
\hline & Simulated & $2,329.2$ & 1.72 & 2.94 & 8.2 & $2,325.8$ & $2,334.0$ & -1.8 & 1.9 \\
\hline \multirow[t]{2}{*}{ TR-78I (188) } & Observed & $2,355.8$ & 2.33 & 5.44 & 9.5 & $2,351.8$ & $2,361.3$ & & \\
\hline & Simulated & $2,354.6$ & 1.42 & 2.02 & 6.7 & $2,351.3$ & $2,358.1$ & 1.1 & 1.3 \\
\hline \multirow[t]{2}{*}{ TR-78J (97) } & Observed & $2,305.5$ & 1.42 & 2.02 & 6.9 & $2,302.6$ & $2,309.5$ & & \\
\hline & Simulated & $2,304.7$ & 1.61 & 2.59 & 7.4 & $2,301.9$ & $2,309.3$ & 0.8 & 1.2 \\
\hline \multirow[t]{2}{*}{ TR-78K (87) } & Observed & $2,290.3$ & 2.93 & 8.60 & 12.3 & $2,285.5$ & $2,297.8$ & & \\
\hline & Simulated & $2,294.2$ & 0.79 & 0.62 & 3.4 & $2,292.6$ & $2,295.9$ & -3.9 & 4.0 \\
\hline \multirow[t]{2}{*}{ TR-78L (100) } & Observed & $2,235.7$ & 3.39 & 11.49 & 13.3 & $2,229.3$ & $2,242.6$ & & \\
\hline & Simulated & $2,237.0$ & 1.28 & 1.64 & 5.6 & $2,234.7$ & $2,240.3$ & -1.4 & 2.5 \\
\hline \multirow[t]{2}{*}{ TR-78M (43) } & Observed & $2,244.9$ & 5.65 & 31.97 & 35.5 & $2,215.1$ & $2,250.6$ & & \\
\hline & Simulated & $2,256.1$ & 1.69 & 2.85 & 6.9 & $2,252.7$ & $2,259.6$ & -11.2 & 11.2 \\
\hline \multirow[t]{2}{*}{ TR-78N (36) } & Observed & $2,337.8$ & 2.15 & 4.60 & 9.9 & $2,332.4$ & $2,342.3$ & & \\
\hline & Simulated & $2,319.9$ & 17.18 & 295.11 & 55.9 & $2,284.6$ & $2,340.5$ & 17.9 & 18.7 \\
\hline \multirow[t]{2}{*}{ TR-79A (83) } & Observed & $2,334.8$ & 2.98 & 8.90 & 11.8 & $2,330.0$ & $2,341.8$ & & \\
\hline & Simulated & $2,334.3$ & 1.49 & 2.22 & 6.5 & $2,331.4$ & $2,337.8$ & 0.5 & 1.5 \\
\hline Mean & -- & -- & -- & -- & -- & -- & -- & -1.6 & 5.1 \\
\hline
\end{tabular}




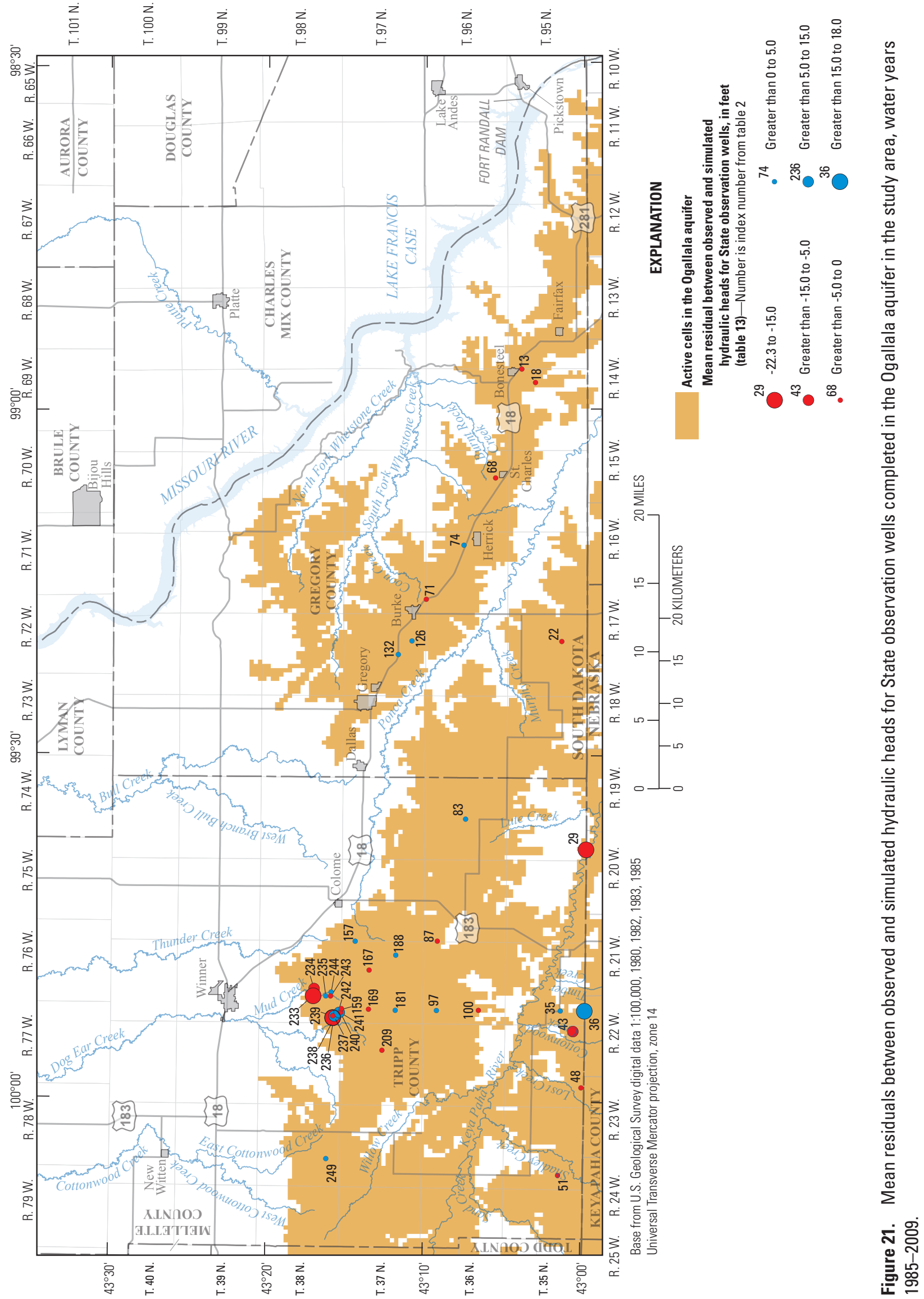




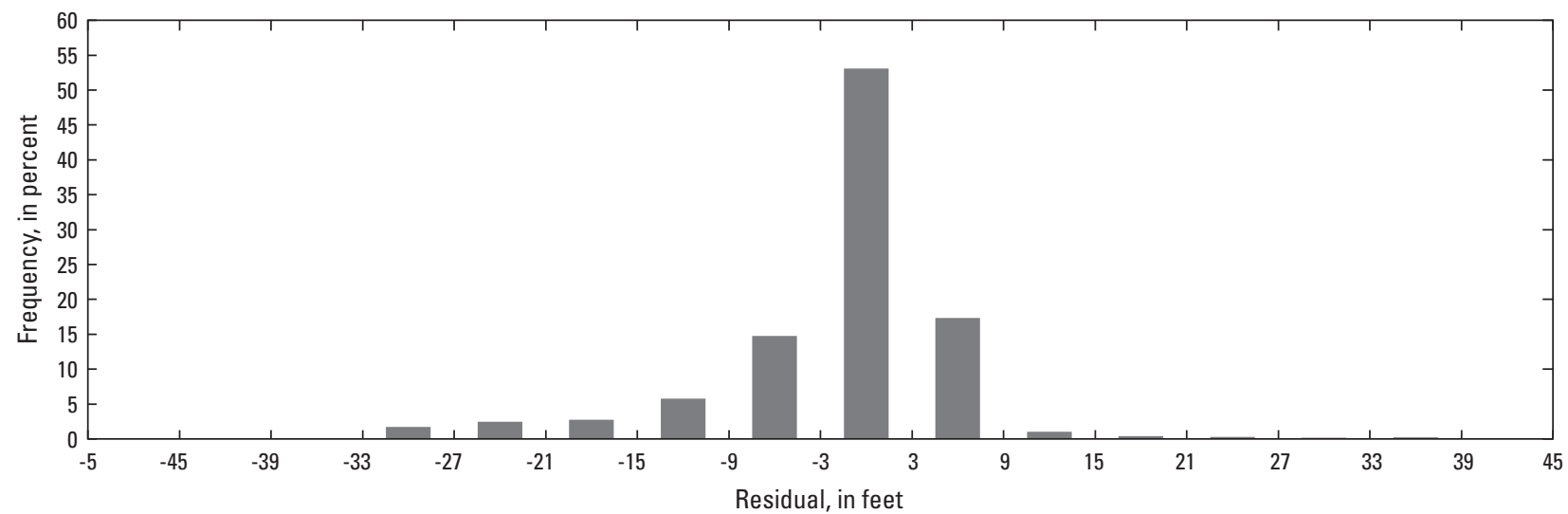

Figure 22. Histogram of residuals of observed and simulated hydraulic head in State observation wells for the 0 gallala aquifer in the study area, water years 1985-2009.

recharge calculated using the SWB method (table 4), except that the synthetic record represented the 30th-percentile recharge rates for each model season of the original record. This resulted in a mean recharge for the drought simulation of $1.89 \mathrm{in} / \mathrm{yr}$, or 60 percent of the original estimated mean recharge rate of $3.14 \mathrm{in} / \mathrm{yr}$. The simulation was executed with a 200-year initialization period using the same recharge rates as the calibration simulation, followed by 75 seasonal stress periods representing 25 years of potential drought conditions. Hydrographs of the hydraulic heads simulated by the calibrated model (non-drought simulation) plotted in relation to hydraulic heads simulated using the drought scenario show the effects of this drought scenario for selected State observation wells (fig. 26). The simulated maximum decrease in water levels of the 38 State observations wells as a result of the drought simulation ranged from 2.28 to $26.2 \mathrm{ft}$, and about 50 percent of the wells had decreases of less than $10.6 \mathrm{ft}$.

The differences in hydraulic head for the study area for the drought scenario compared with the non-drought simulation ranged from 0 to $30 \mathrm{ft}$, with a mean of $6.05 \mathrm{ft}$ for the Ogallala aquifer (fig. 27). Generally, the largest differences were in the central and southern parts of Tripp County where groundwater withdrawals from wells are greatest.

To assess the effects of potential increases in pumping, well withdrawal rates for production wells were increased by 50 percent from those that were used during the calibrated simulation (tables 7 and 8). The potential effects of pumping were simulated using the same 200-year initialization period followed by 75 seasonal stress periods representing 25 years of increased pumping. The simulated maximum decrease in water levels for the 38 State observation wells ranged from 0.02 to $25.0 \mathrm{ft}$, and about 50 percent of observation wells had a maximum difference of $0.6 \mathrm{ft}$. The decreases in hydraulic heads in the study area between the results of the calibrated model and the scenario of increased pumping at the end of the 25 -year simulation ranged from 0 to $26 \mathrm{ft}$, with a mean difference of $0.14 \mathrm{ft}$ for the Ogallala aquifer (fig. 28). Generally, the greatest differences in simulated hydraulic heads between the calibrated model and the increased pumping scenario were in the central and southern parts of Tripp County and southeast of the town of Gregory where the current (2009) groundwater withdrawals from wells are greatest.

\section{Comparison of Simulated Groundwater Budgets}

For the long-term initialization period, the aquifer received about 92 percent of its simulated inflow as recharge from precipitation, less than 1 percent from river leakage, and about 8 percent as lateral flow through specified-head cells on the western and southern model boundaries (table 15). For the initialization period, about 75 percent of simulated outflow was from evapotranspiration, 12 percent was discharged through springs and seeps, 9 percent was discharged to streams through riverbed material, 2 percent was removed through well withdrawals, and 2 percent of water exited the model through specified-head boundaries. The simulated change in storage for the initialization period was zero.

The transient distribution of evapotranspiration and recharge from precipitation for WYs 1985-2009 altered the water budget components from the initialization period. Simulated recharge from precipitation accounted for about 94 percent of inflows for the aquifer, lateral flow through specified-head boundaries accounted for 6 percent of inflows, and recharge from river leakage accounted for less than 1 percent. Simulated outflow from the aquifer was through evapotranspiration (70 percent), river leakage (11 percent), spring and seepage discharge (15 percent), well withdrawals ( 2 percent), and lateral outflow through specified-head boundaries ( 3 percent).

As expected, the simulation representing a potential drought scenario showed much less water entering the aquifer as recharge from precipitation ( 84 percent). Simulated river leakage accounted for 1 percent of inflow to the aquifer, and lateral inflow through specified-head boundaries accounted for 15 percent of inflows. The potential drought scenario simulation had much less water leaving the aquifer though evapotranspiration (65 percent), river leakage (12 percent), and 

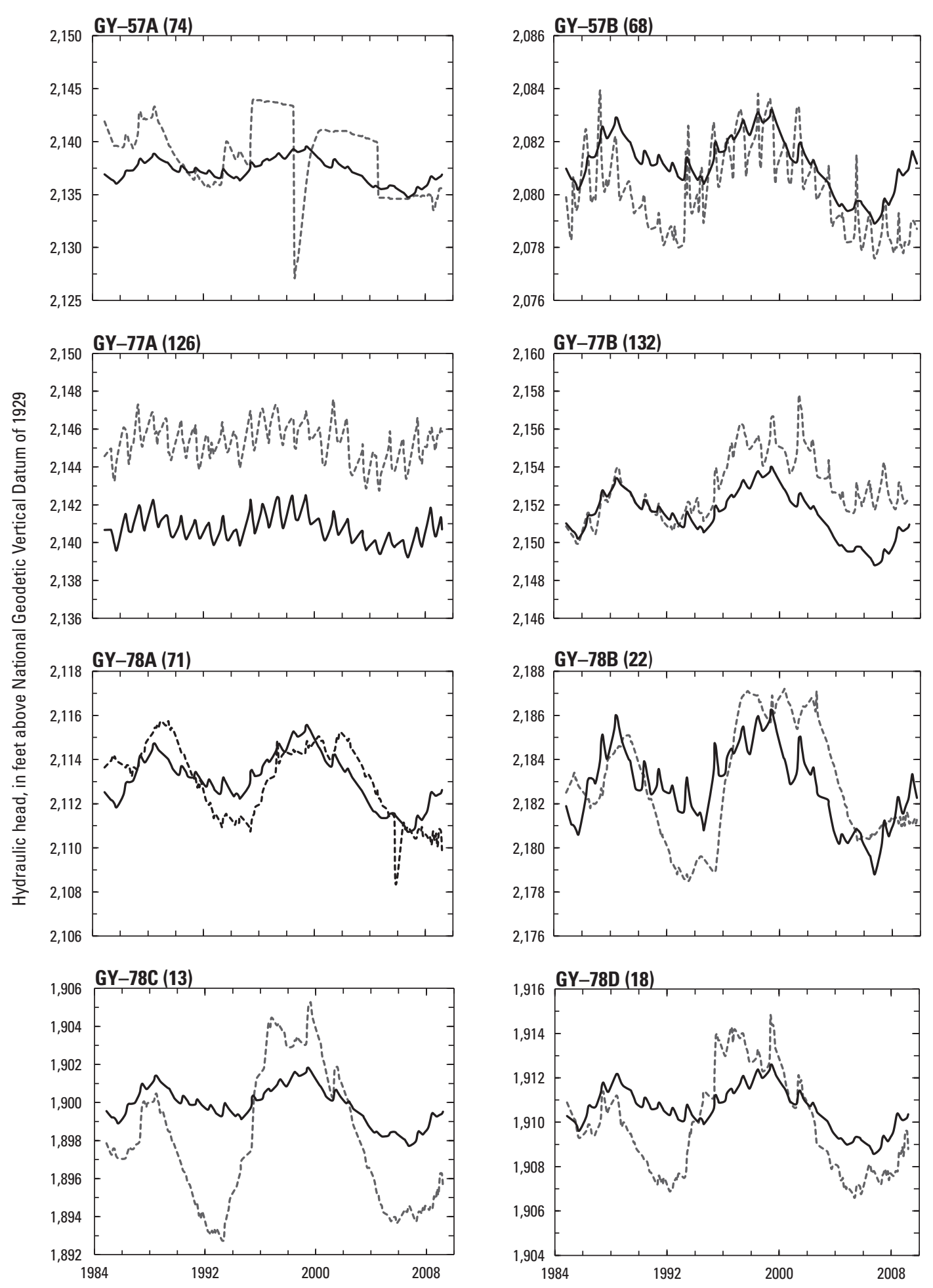

Calendar year

EXPLANATION

Figure 23. Observed and simulated hydraulic heads for State observation wells completed in the Ogallala aquifer in the study area. The numbers in parentheses are the index number for the well as shown on figure 21. The State observation wells are listed in table 2. 

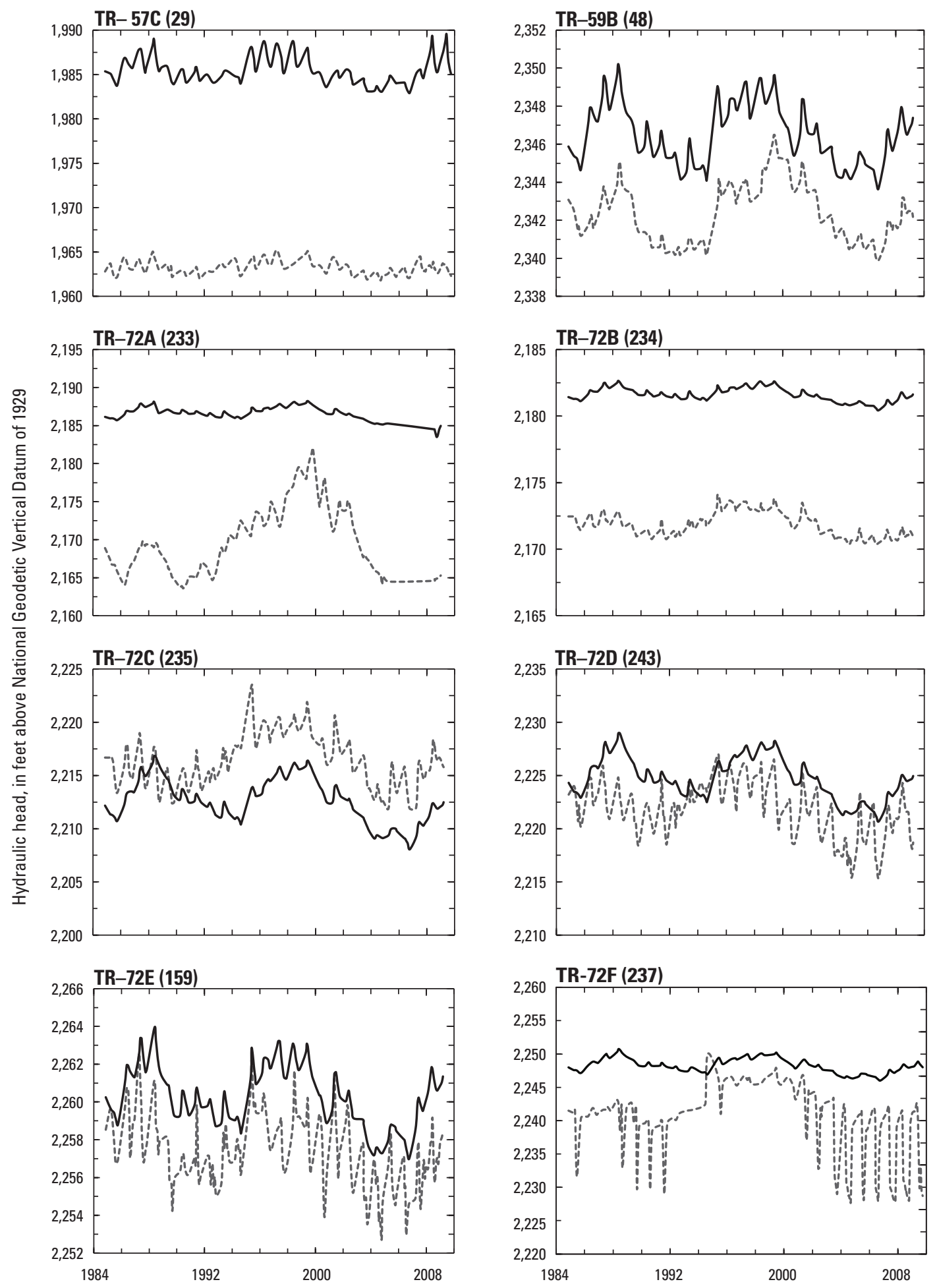

Calendar year

EXPLANATION

------ Observed Simulated

Figure 23. Observed and simulated hydraulic heads for State observation wells completed in the Ogallala aquifer in the study area. The numbers in parentheses are the index number for the well as shown on figure 21. The State observation wells are listed in table 2.-Continued 
TR-72G (238)
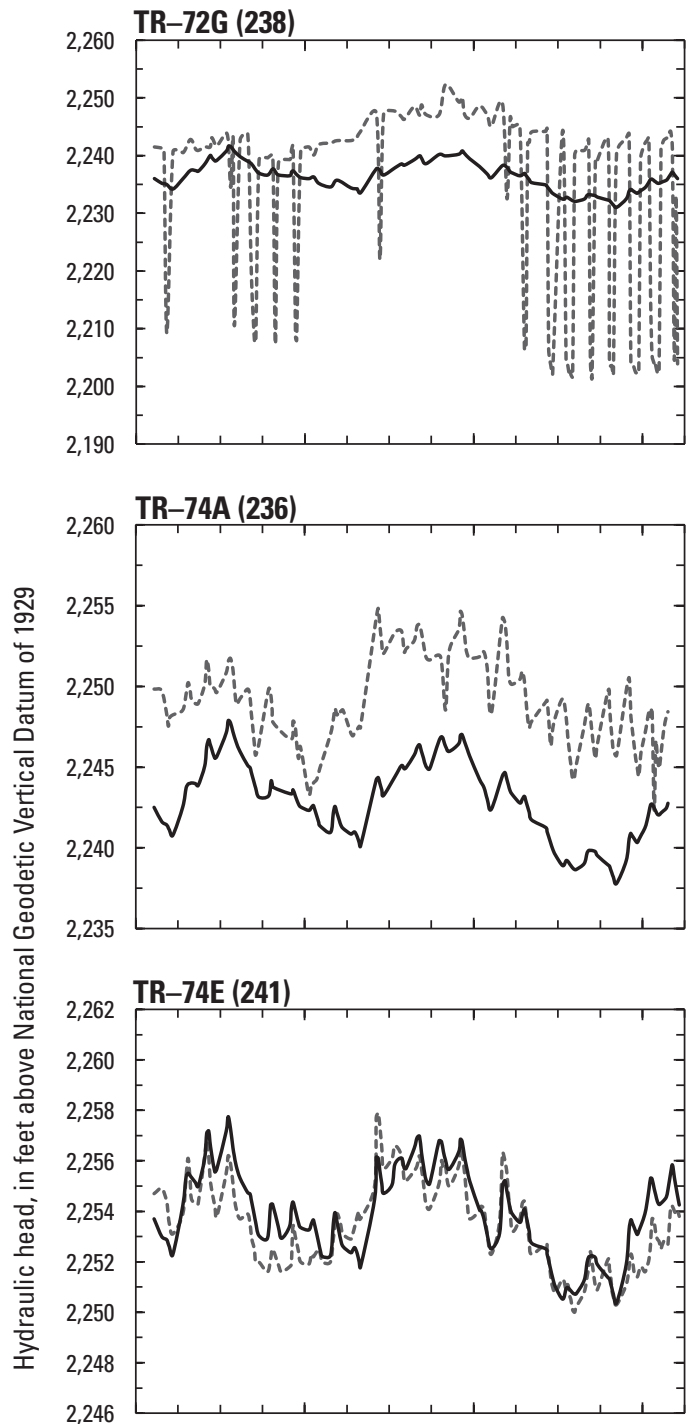

TR-75B (244)

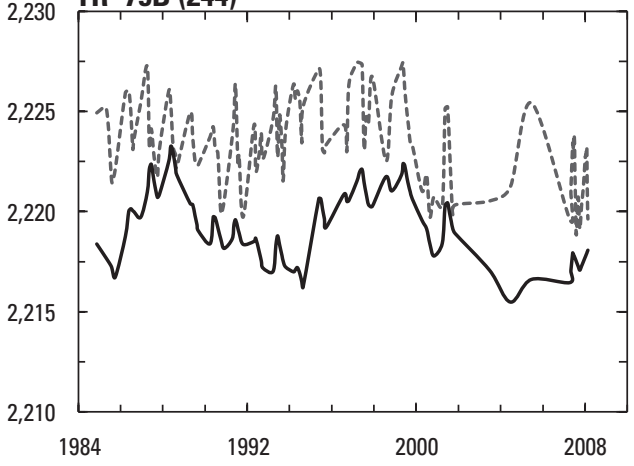

TR-72H (239)
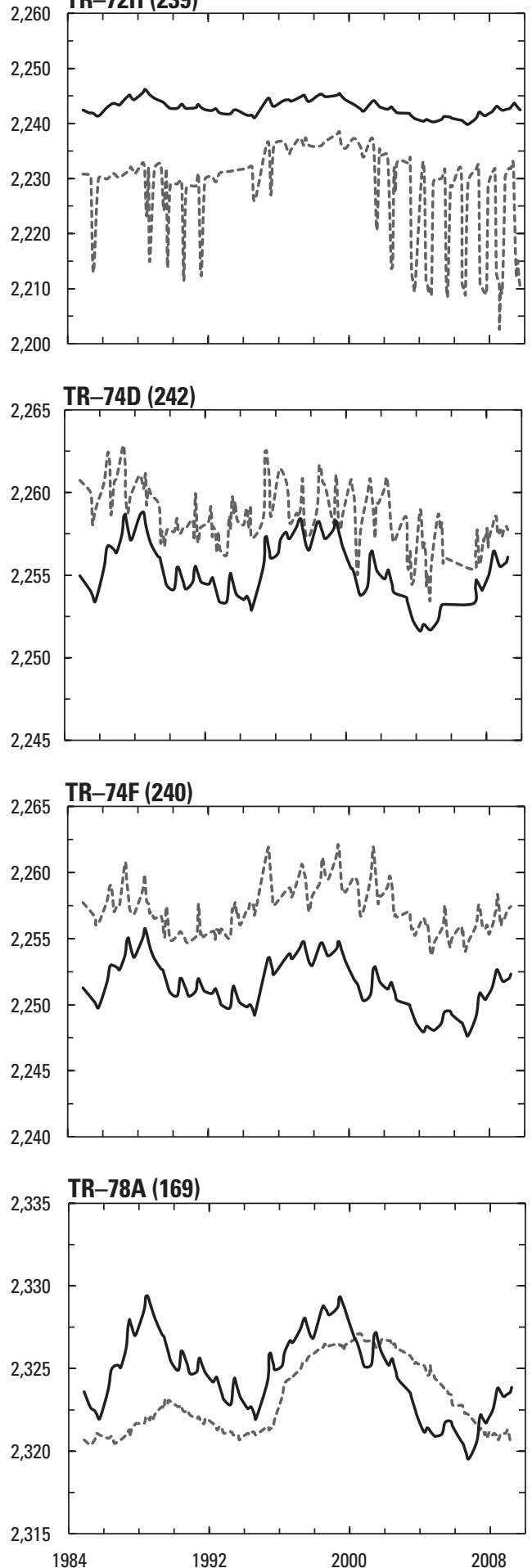

Calendar year

EXPLANATION

------- Observed $\longrightarrow$ Simulated

Figure 23. Observed and simulated hydraulic heads for State observation wells completed in the Ogallala aquifer in the study area. The numbers in parentheses are the index number for the well as shown on figure 21. The State observation wells are listed in table 2.-Continued 


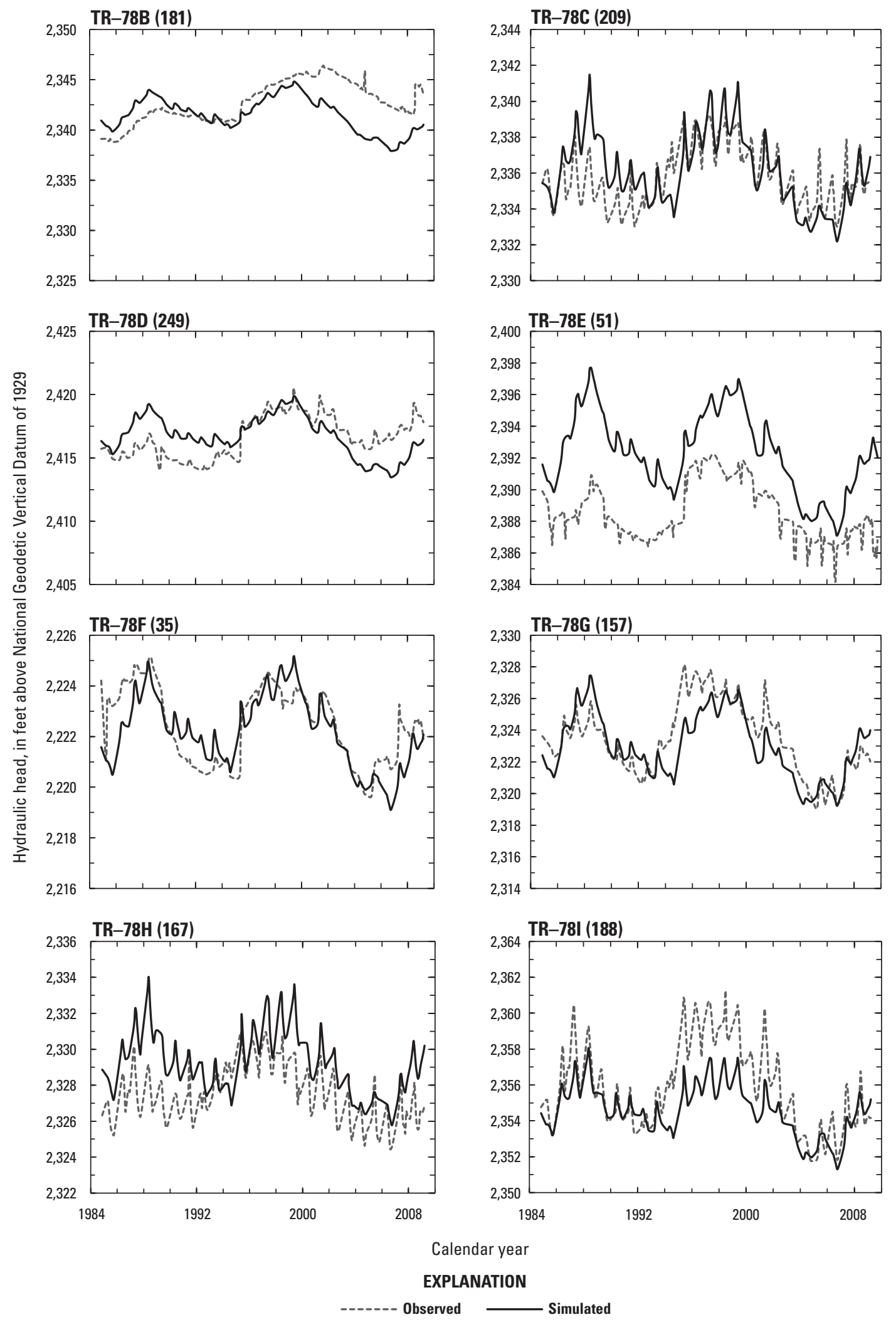

Figure 23. Observed and simulated hydraulic heads for State observation wells completed in the Ogallala aquifer in the study area. The numbers in parentheses are the index number for the well as shown on figure 21. The State observation wells are listed in table 2.-Continued 


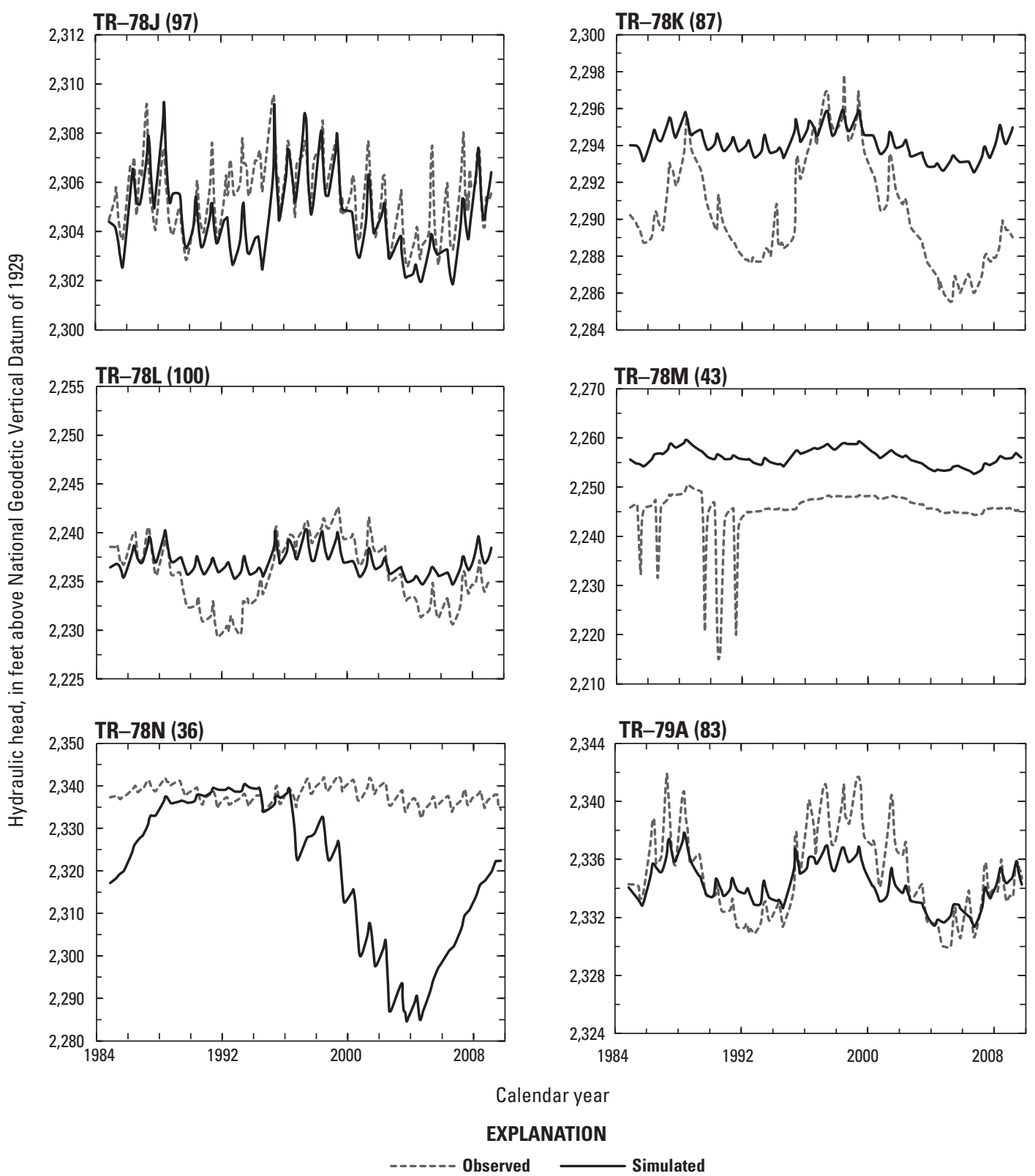

Figure 23. Observed and simulated hydraulic heads for State observation wells completed in the Ogallala aquifer in the study area. The numbers in parentheses are the index number for the well as shown on figure 21. The State observation wells are listed in table 2.-Continued 


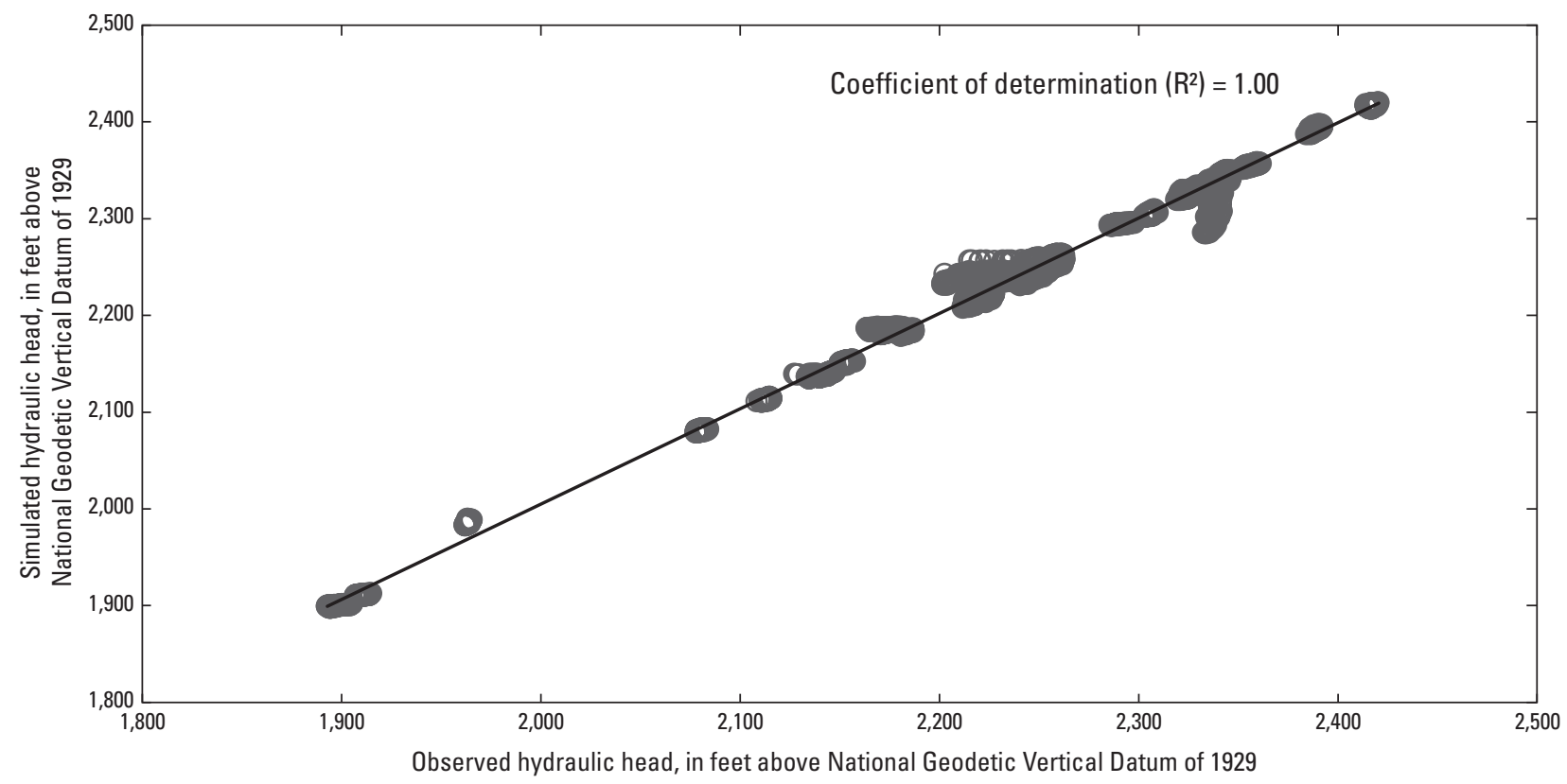

Figure 24. Linear regression of observed and simulated hydraulic heads for State observation wells in the Ogallala aquifer in the study area.

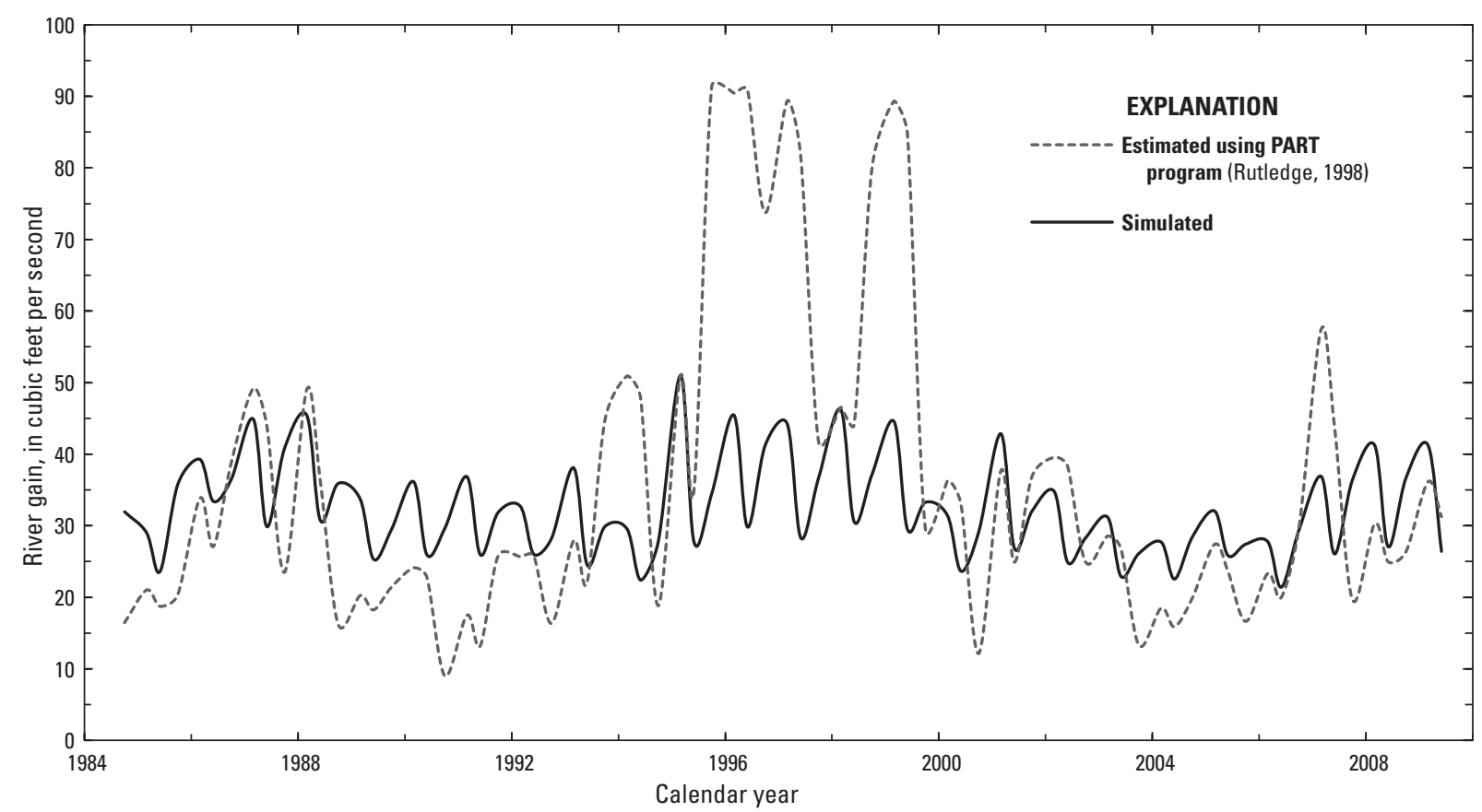

Figure 25. Estimated and simulated base flow from groundwater discharge from the Ogallala aquifer in the study area for the Keya Paha River. 
Table 14. Comparison of estimated to simulated base flow for the Keya Paha River for the transient simulation.

$\left[\mathrm{ft}^{3} / \mathrm{s}\right.$, cubic feet per second]

\begin{tabular}{|c|c|c|}
\hline \multirow{2}{*}{ Water year } & \multicolumn{2}{|c|}{$\begin{array}{c}\text { Base flow } \\
\left(\mathbf{f t}^{3} / \mathbf{s}\right)\end{array}$} \\
\hline & Estimated $^{b}$ & Simulated \\
\hline 1985 & 18.7 & 28.2 \\
\hline 1986 & 27.1 & 36.2 \\
\hline 1987 & 44.0 & 37.1 \\
\hline 1988 & 36.3 & 39.0 \\
\hline 1989 & 18.2 & 31.6 \\
\hline 1990 & 22.8 & 30.5 \\
\hline 1991 & 13.3 & 30.8 \\
\hline 1992 & 25.7 & 30.2 \\
\hline 1993 & 22.1 & 30.3 \\
\hline 1994 & 47.9 & 27.3 \\
\hline 1995 & 34.9 & 35.5 \\
\hline 1996 & 90.9 & 36.6 \\
\hline 1997 & 81.6 & 37.9 \\
\hline 1998 & 44.1 & 37.8 \\
\hline 1999 & 84.6 & 37.1 \\
\hline 2000 & 33.0 & 29.4 \\
\hline 2001 & 24.9 & 33.0 \\
\hline 2002 & 38.3 & 30.6 \\
\hline 2003 & 26.7 & 27.5 \\
\hline 2004 & 15.9 & 25.5 \\
\hline 2005 & 23.7 & 28.8 \\
\hline 2006 & 20.0 & 25.5 \\
\hline 2007 & 43.7 & 30.8 \\
\hline 2008 & 25.0 & 34.9 \\
\hline 2009 & 31.3 & 34.8 \\
\hline Mean & 35.8 & 32.3 \\
\hline
\end{tabular}

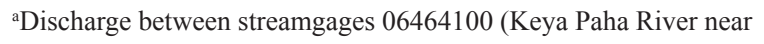
Keyapaha) and 06464500 (Keya Paha River at Wewela). Includes springflow and seeps along river banks.

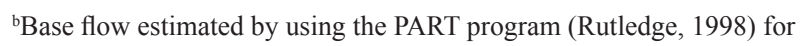
the conceptual model.

discharge through springs and seeps (16 percent). Simulated discharge from the Ogallala aquifer through river leakage, springs, and seeps for the drought scenario accounted for a larger portion of the water budget when compared with the simulation representing WYs 1985-2009, although the amount of water being discharged was less in comparison (table 15). The decrease in discharge from river leakage, springs, and seeps as well as the decrease in simulated evapotranspiration for the drought scenario likely is due to substantial decreases in the potentiometric surface (fig. 27) for the simulation period. Well withdrawals accounted for 3 percent of simulated outflow, and leakage through specified-head boundaries accounted for 3 percent of simulated outflow.

The simulated groundwater budget representing a potential increased pumping scenario was similar to the groundwater budget for WYs 1985-2009, although well withdrawals accounted for a slightly larger portion of simulated outflow (3 percent), and river leakage and evapotranspiration accounted for a slightly smaller portion of simulated outflow (10 and 69 percent, respectively) for the increased pumping scenario. Simulated discharge from springs and seeps decreased slightly from 39.0 to $38.7 \mathrm{ft}^{3} / \mathrm{s}$ but still accounted for 15 percent of total simulated outflow. Simulated inflow for the potential increased pumping scenario was the same as WYs 1985-2009. Simulated outflow from river leakage, spring and seepage discharge, and lateral flow through specified-head boundaries was the same for both budget periods. The decrease in evapotranspiration for the potential increased pumping scenario is likely due the water-level decreases near pumping wells. The amount of simulated discharge from river leakage did not decrease as a result of a 50-percent increase in withdrawals from existing production wells.

\section{Model Limitations}

The numerical model adequately simulated flow in the Ogallala aquifer in the study area for transient and potential future conditions. However, as with any conceptual or numerical model, certain limitations should be considered. These include uncertainties in many of the numerical model input parameters, most importantly recharge, evapotranspiration, and horizontal hydraulic conductivity. These parameters greatly affected model results, and extensive parameter data were not available. Therefore, these parameters were estimated or calculated with the data that were available. Recharge was calculated by subtracting evapotranspiration from precipitation using the SWB method, which included assumptions and limitations inherent to the SWB method.

Driller's completion reports and lithologic logs were used to determine hydrogeologic properties such as the base of the aquifer. In many parts of the study area, data were sparse, and driller's completion reports were the only available source of hydrogeologic information. The reliability of information from driller's completion reports was largely unknown. As a result, completion reports and lithologic logs with descriptive well locations and hydrogeologic information were given priority. In some cases, hydrogeologic properties were interpolated over large distances. The conceptualization of the hydrogeologic properties of the Ogallala aquifer was dependent on the spatial availability of hydrogeologic information and the interpolation methods used.

Groundwater discharge locations, primarily seeps, springs, and wells, were assumed based on available information. Ephemeral stream drainages were used to approximately locate springs and seeps along the contact between the Ogallala Formation and underlying geologic units. Well locations 


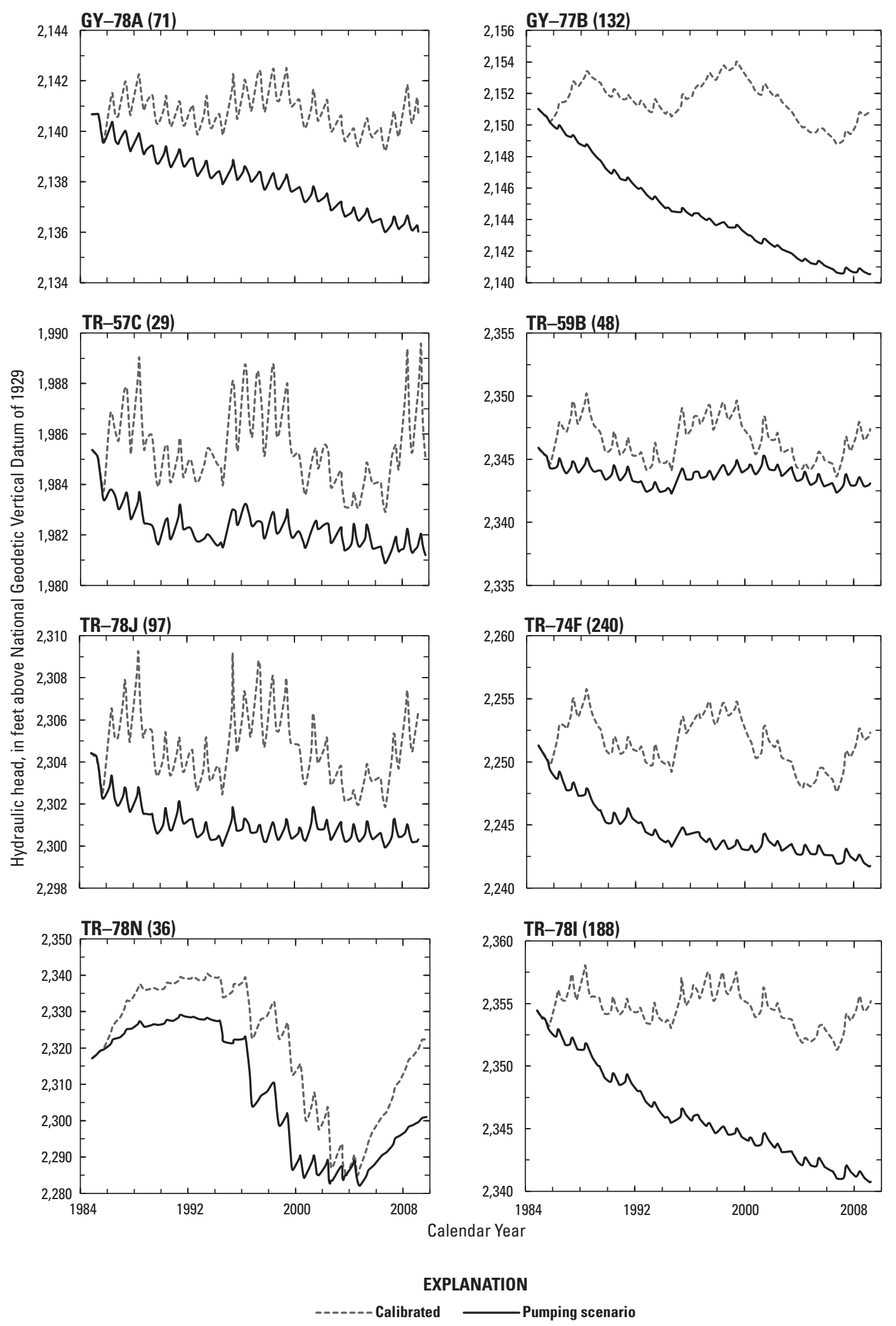

Figure 26. The difference in hydraulic heads between the results of the calibrated model (non-drought simulation) and the assumed potential drought scenario for the 25-year simulation period for selected State observation wells completed in the Ogallala aquifer in the study area. The numbers in parentheses are the index number for the well as shown on figure 21. The State observation wells are listed in table 2. 

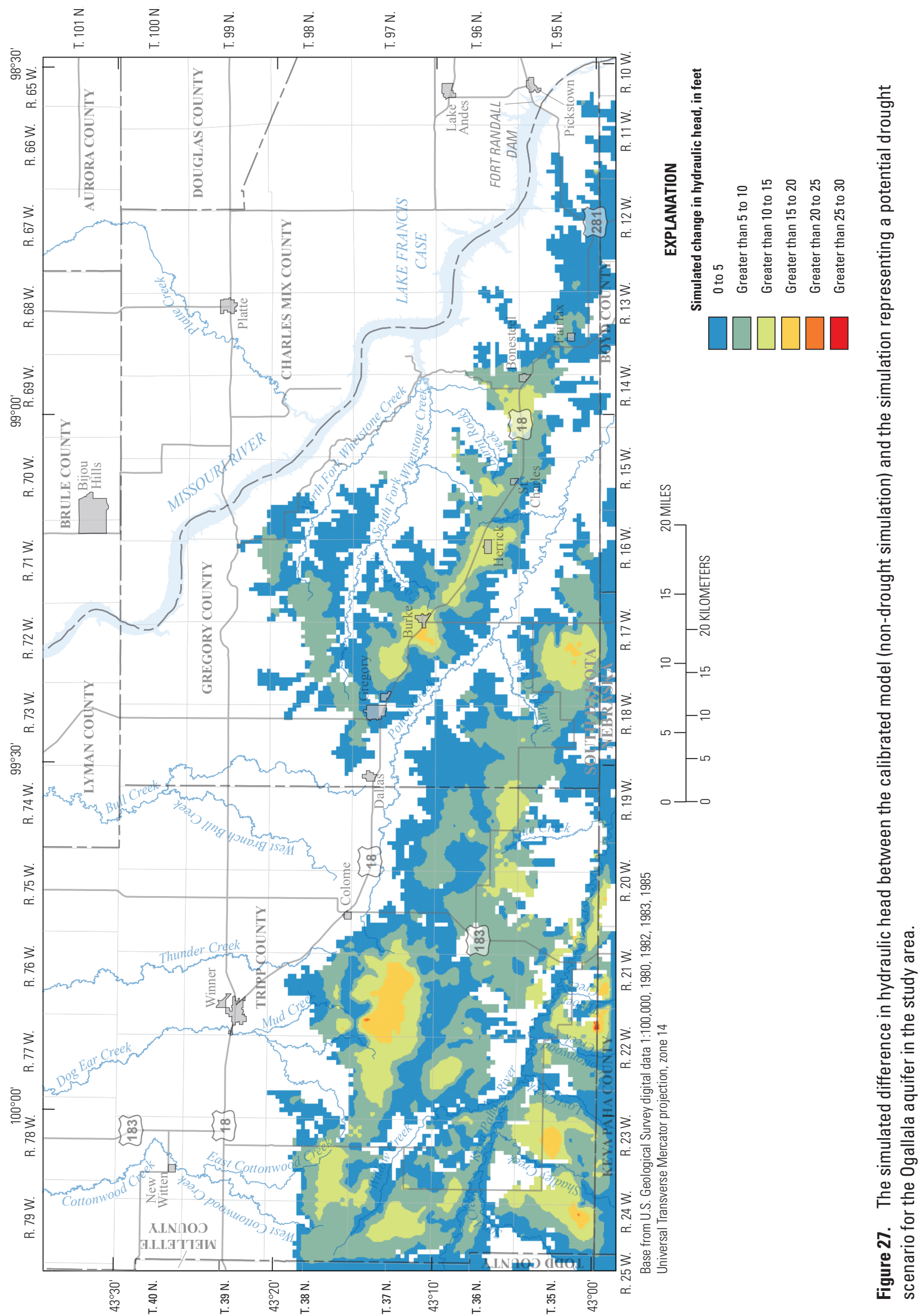


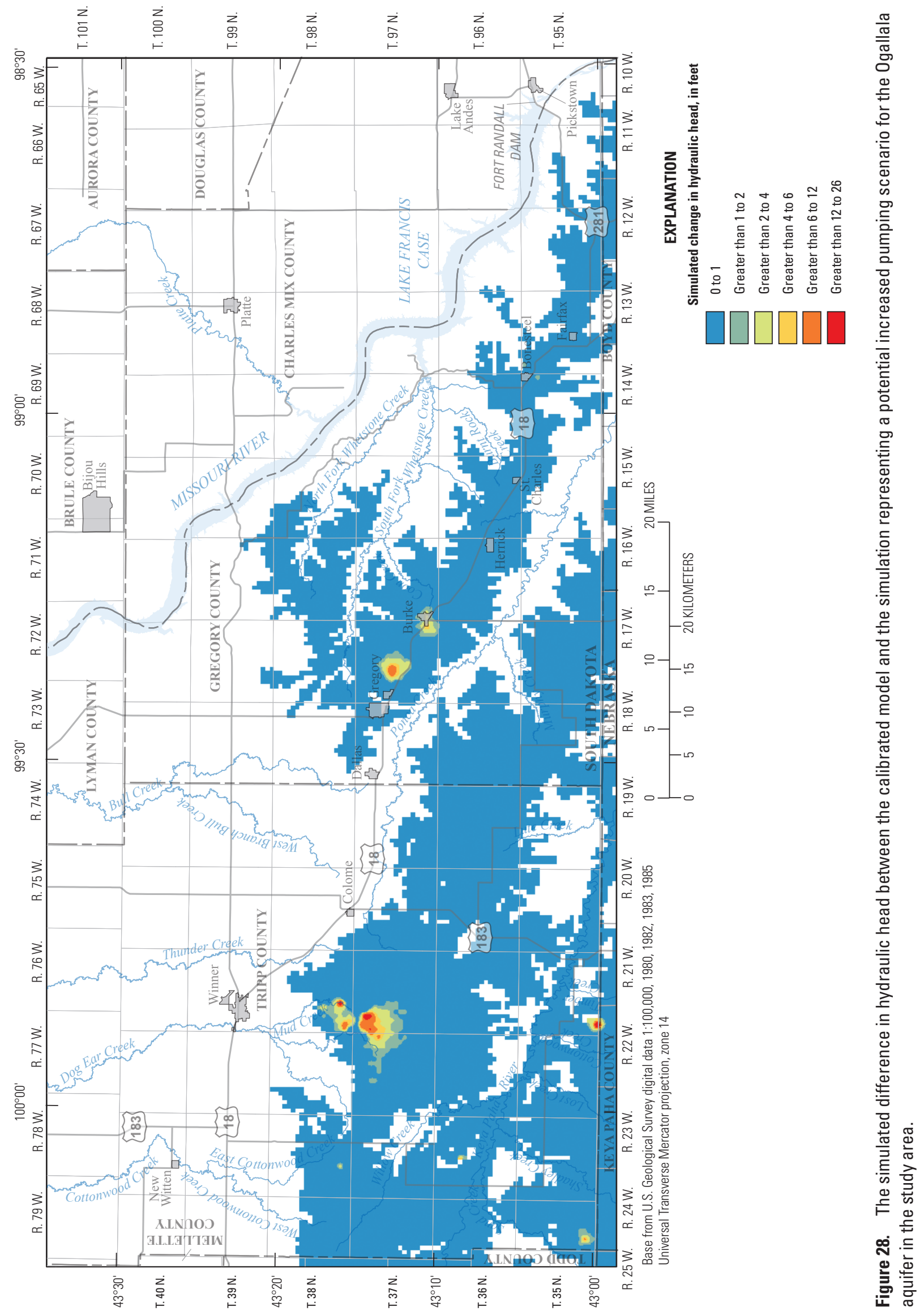


Table 15. Simulated groundwater budget for the initialization period, water years 1985-2009, potential drought scenario, and potential increased pumping scenario for the Ogallala aquifer in the study area.

$[<$, less than; --, not estimated or not applicable]

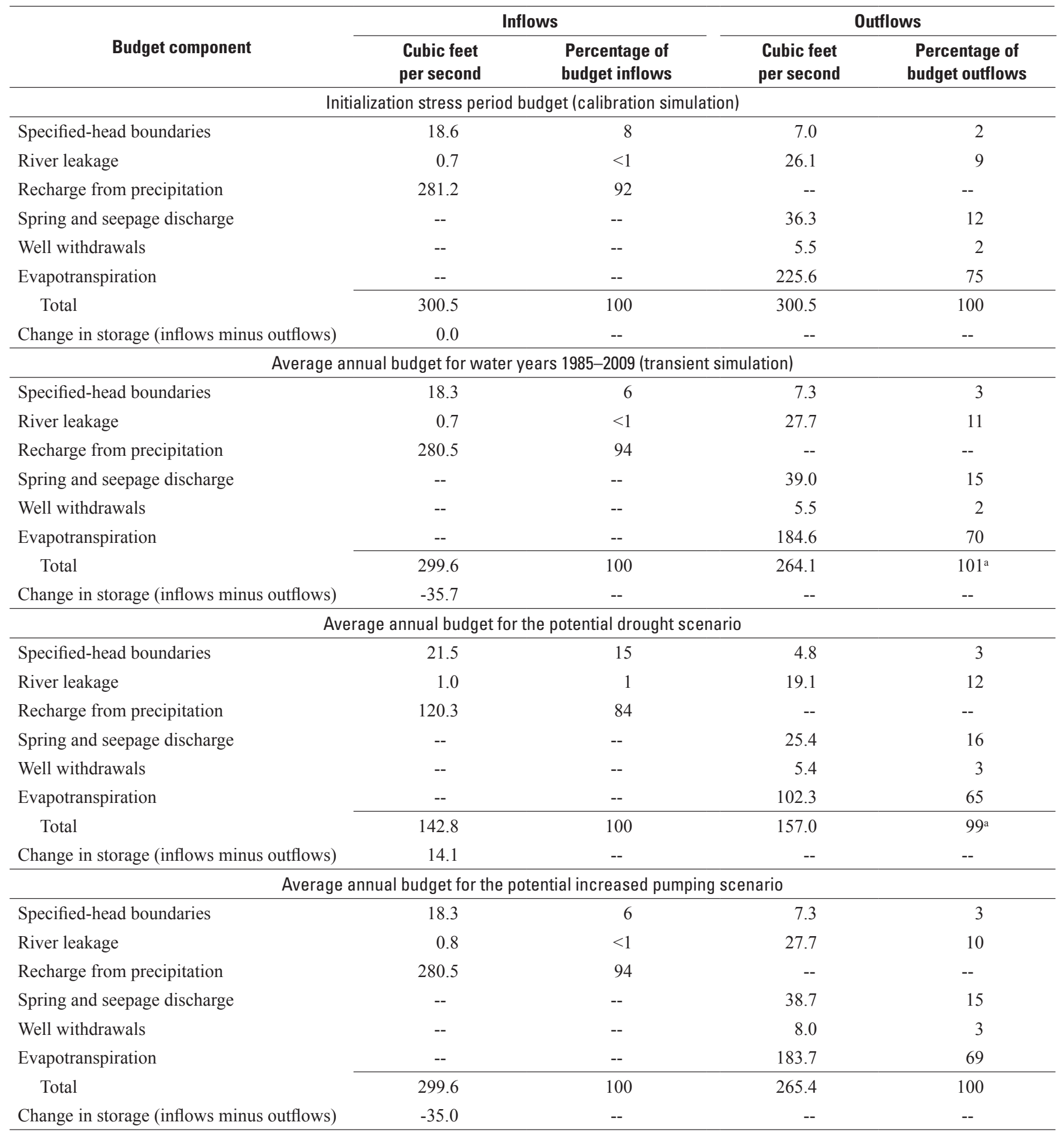

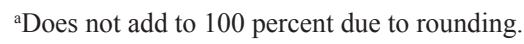


were determined from driller's completion logs, previous investigations, and water-use permits. In many cases, the actual well location was unknown, and therefore, the location was assumed based on the legal location provided in the source document. Assumed discharge locations affected local and regional groundwater-flow directions and the subsequently simulated hydraulic heads and discharges in the study area.

Better quantification of discharge locations would improve the model's ability to accurately simulate groundwater-flow directions, hydraulic heads, and discharge volumes in the study area.

Groundwater flow between the Ogallala aquifer and underlying hydrogeologic units was assumed to be negligible. In other parts of South Dakota, the Ogallala aquifer is hydraulically connected to underlying hydrogeologic units such as the Arikaree aquifer (Long and Putnam, 2010). Little information was available that indicated the Arikaree aquifer was a substantial source of groundwater in the study area; therefore, the assumption that the Arikaree aquifer serves as the lower impermeable boundary of the Ogallala aquifer within the study area seems appropriate.

Ranges of hydraulic conductivity used in the numerical model were based on general ranges of previously published values, but final values were determined through model calibration. The model's accuracy is dependent, in part, on the accuracy of the estimates of model parameters. Calibration of the model yielded a hydraulic conductivity distribution that was acceptable, given the data available, but it is reasonable to assume that similar hydraulic conductivity distributions could exist that also would yield satisfactory model results. Given the depositional origin of the Ogallala Formation, horizontal hydraulic conductivity anisotropy was assumed to exist in the Ogallala aquifer. Multiple anisotropy magnitudes and directions were tested to achieve the best fit between observed and simulated hydraulic head in the aquifer. The final anisotropy direction was coincident with the general flow direction of major streams within the study area. It is likely that the final horizontal hydraulic conductivity distribution was dependent on the accuracy of the horizontal anisotropy. Without more field data, a different hydraulic conductivity distribution and horizontal anisotropy cannot be verified.

Parameter values representing recharge and evapotranspiration were optimized to their upper limits during the calibration process and likely were the result of sparse flow data for the aquifer; therefore, the results of the calibration process are non-unique. The two primary calibration objectives for the model were to simulate transient hydraulic heads and discharge as base flow in the Keya Paha River. Because sparse discharge information was available in some parts of the study area, hydraulic-head measurements were the only means of calibration in those areas. An increase in simulated recharge was offset by an increase in evapotranspiration, and the parameters increased to their plausible limits. Even though the solution is non-unique, the remaining parameter estimates are a result of the plausible limits assigned to those parameters.
The calibration targets all contain error, which contributed to uncertainty in parameter estimation. It is difficult to quantify the error and uncertainty of individual targets. The two calibration targets, transient hydraulic-head measurements and discharge to the Keya Paha River, were used to the extent of available information. The number of calibration targets for individual hydraulic-head measurements at State observation wells was much greater compared to the number of calibration targets for base-flow estimates. To account for variability in the frequency of measurements associated with calibration targets, individual targets for base flow were given more weight in the calibration process, and individual hydraulic-head targets were given less weight. This weighting scheme was used to prevent the model calibration process from becoming biased to one calibration target type compared to the other.

Simulated hydraulic heads at State observation wells and simulated base flow generally had less seasonal variability when compared with observed or estimated values (figs. 23 and 25). A single-layer model grid with 1,640-ft spacing was determined to be sufficient spatial discretization, and three stress periods per year were determined to be sufficient temporal discretization for the scale of the model. The discretization of spatially varied aquifer parameters and temporally varied aquifer stresses likely smooth simulated changes in hydraulic head and base flow for the study area.

\section{Summary}

The Ogallala aquifer is an important water resource for the Rosebud Sioux Tribe in Gregory and Tripp Counties in South Dakota. The Ogallala aquifer is used extensively for irrigation and for public supply, domestic, and stock water supplies. Continued or increased withdrawals from the Ogallala aquifer in Gregory and Tripp Counties have the potential to affect water levels within the aquifer and base flow discharge to streams in the area. A water resource tool was needed to better understand management and environmental issues associated with the Ogallala aquifer, such as estimating the effects of various hydrologic stresses. These stresses include prolonged drought and increased groundwater withdrawal. To address this need, a conceptual model and a numerical model to simulate groundwater flow in the Ogallala aquifer in Gregory and Tripp Counties were developed by the U.S. Geological Survey in cooperation with the Rosebud Sioux Tribe. This report describes a conceptual model of groundwater flow in the aquifer and documents the development and calibration of the numerical model to simulate groundwater flow. Data for a 25-year period (water years 1985-2009) were analyzed for the conceptual model, and transient simulations were performed for the same 25-year period.

Regional flow in the Ogallala aquifer enters the study area from the west and southwest and exits the study area to the southeast. Recharge to the Ogallala aquifer occurs from precipitation on the outcrop areas. Groundwater from 
precipitation recharge moves from areas of high altitude toward streams that gain flow from the Ogallala aquifer. Discharge from the Ogallala aquifer occurs through evapotranspiration, discharge to streams, and well withdrawals. Evapotranspiration generally occurs in topographically low areas along streams, and maximum evapotranspiration occurs when the water level is at the land surface. Base flow was estimated for two streamgages on the Keya Paha River using a hydrograph separation method. The 25 -year estimated mean base flow was 35.8 cubic feet per second $\left(\mathrm{ft}^{3} / \mathrm{s}\right)$ for the Keya Paha River.

Well withdrawals in the study area are from irrigation, public supply, domestic, and stock wells. Mean annual withdrawals for irrigation were $1.1 \mathrm{ft}^{3} / \mathrm{s}$, and mean annual public supply use was estimated to be $4.38 \mathrm{ft}^{3} / \mathrm{s}$. Withdrawals for individual domestic and stock wells were not accounted for individually because the total withdrawals from domestic and stock wells were assumed to account for a small fraction of the total water budget for the study area.

The conceptual model of groundwater flow was simulated as a single-layer numerical model using MODFLOWNWT. The single layer model represented the Ogallala aquifer. The study was divided into grid blocks 500 meters [1,640 feet (ft)] on each side, with 282 rows and 133 columns. Cell heights were equal to the mean formation thickness in each cell. Combinations of constant-head and no-flow boundaries were used to best represent boundary conditions.

Hydraulic conductivity for the numerical model was represented using pilot points. Actual values were interpolated to the model domain and assigned to individual model cells. The vertical hydraulic conductivity used for the numerical model was assumed to be a uniform ratio of 10 percent of the horizontal hydraulic conductivity. Uniform storage coefficient and specific yield values were used for the numerical model.

Model calibration was accomplished using a parameter estimation program that adjusted individual model input parameters and assessed the difference between estimated and model simulated values of hydraulic head and base flow. A simulation that included an initialization period calibrated to steady-state conditions and transient stress periods calibrated to transient conditions was analyzed to optimize model parameters. The potentiometric surface calculated from the initialization part of the simulation was used to establish the initial conditions for the transient part of the simulation. Water-level measurements were available for 38 observation wells and 223 test holes and private wells. A sensitivity analysis was used to examine the response of the calibrated model to changes in model parameter values. The model was most sensitive to recharge and maximum potential evapotranspiration and least sensitive to riverbed and spring conductances.

Calibrated hydraulic conductivity for the numerical model ranged from 0.9 to 227 feet per day in the Ogallala aquifer. The annual recharge rates for the numerical model for the transient simulation (water years 1985-2009) ranged from 0.60 to 6.96 inches, with a mean of 3.68 inches for the Ogallala aquifer. This represents a mean recharge rate of $280.5 \mathrm{ft}^{3} / \mathrm{s}$ for the model area. Simulated annual evapotranspiration rates ranged from about 128 to $254 \mathrm{ft}^{3} / \mathrm{s}$, and net discharge to streams through river leakage and flow from springs and seeps ranged from 52.2 to $79.9 \mathrm{ft}^{3} / \mathrm{s}$. Mean annual discharge rates were about $185 \mathrm{ft}^{3} / \mathrm{s}$ for evapotranspiration, $66.7 \mathrm{ft}^{3} / \mathrm{s}$ for discharge to streams, and $5.48 \mathrm{ft}^{3} / \mathrm{s}$ for well withdrawals.

Constant values for storage coefficient and specific yield were used for the numerical model. The storage coefficient was 0.004 and specific yield was 0.13 .

Calibration objectives for the simulation included (1) simulating the long-term mean potentiometric surface and hydraulic gradients to those of the mapped potentiometric surface, (2) balancing inflows and outflows for the steady-state part of the simulation, (3) matching trends in hydrographs and hydraulic heads for the 38 State observation wells at 95 percent of wells to within plus or minus $25 \mathrm{ft}$ of observed hydraulic heads, and (4) matching the trends in the base flow hydrograph for the Keya Paha River.

Potential future scenarios were simulated using the input parameters from the calibrated simulation and included a potential drought and a potential increased pumping scenario. To simulate a potential drought scenario, a synthetic drought record was created, the mean of which was equal to 60 percent of the mean estimated recharge rate for the 25-year simulation period. The potential drought scenario resulted in water-level decreases as much as $30 \mathrm{ft}$ when compared with the calibrated simulation. To simulate the effects of potential increases in future pumping, production well withdrawal rates were increased by 50 percent from those estimated for the 25-year simulation period. The simulation representing an increased pumping scenario resulted in water-level decreases of as much as $26 \mathrm{ft}$ when compared with the calibrated simulation.

Groundwater budgets for the potential future scenario simulation were compared with the water budgets for the simulation for water years 1985-2009. Compared with the simulation for water years 1985-2009, the simulation that represented a potential drought scenario resulted in lower aquifer recharge from precipitation and decreased discharge from streams, springs, seeps, and evapotranspiration. The simulated groundwater budget that represented a potential increased pumping scenario was similar to the groundwater budget for water years 1985-2009, although well withdrawals accounted for a slightly larger portion of simulated outflow and river leakage, and evapotranspiration accounted for a slightly smaller portion of simulated outflow for the increased pumping scenario.

The numerical model is a tool that could be used to better understand the flow system of the Ogallala aquifer in Gregory and Tripp Counties. The long-term hydraulic-head measurements were simulated reasonably well using the numerical model. Discharge from the Ogallala aquifer to rivers, springs, and seeps was simulated using the model with reasonable accuracy where data were available. 


\section{References Cited}

Canadell, J., Jackson, R.B., Ehleringer, J.R., Mooney, H.A., Sala, O.E., and Schulze, E.-D., 1996, Maximum rooting depth of vegetation types at the global scale: Oecologia, v. 108, p. 583-595, accessed January 20, 2011, at http:// biology.duke.edu/jackson/oecol96d.pdf.

Carter, J.M., 1998, Water resources of Mellette and Todd Counties, South Dakota: U.S. Geological Survey WaterResources Investigations Report 98-4146, 68 p. (Also available at http://pubs.usgs.gov/wri/wri984146/.)

City of Winner, South Dakota, 2012, Water: City of Winner, South Dakota, accessed January 27, 2012, at http://www. winnersd.com/water.html.

Curve Number Work Group, 2004, Hydrologic soil-cover complexes, chap. 9 of National engineering handbook, Part 630-Hydrology: U.S. Department of Agriculture, Natural Resources Conservation Service/Agricultural Research Service 210-VI-NEH, 20 p., accessed June 28, 2010, at ftp:// ftp.wcc.nrcs.usda.gov/wntsc/H\&H/NEHhydrology/ch9.pdf.

Dennehy, K.F., 2000, High Plains regional ground-water study: U.S. Geological Survey Fact Sheet 2000-091, 2 p. (Also available at http://pubs.usgs.gov/fs/2000/0091/report. $p d f$.)

Diffendal, R.F., and Voorhies, M.R., 1994, Geologic framework of the Niobrara River drainage basin and adjacent areas in South Dakota generally east of the 100th meridian west longitude and west of the Missouri River: Nebraska Geological Survey Report of Investigations No. 9, 13 p. (Also available at http://digitalcommons.unl.edu/cgi/ viewcontent.cgi? article $=1093 \&$ context $=$ geosciencefacpub.)

Doherty, John, 2003, Ground water model calibration using pilot points and regularization: Ground Water, v. 41, no. 2, p. 170-177. (Also available at http://info.ngwa.org/gwol/ pdf/031075995.pdf.)

Doherty, J.E., 2008, Manual for the groundwater data utilities-PEST: accessed November 20, 2012, at http://www. pesthomepage.org/Downloads.php.

Doherty, J.E., 2010, PEST-Model-independent parameter estimation-User manual (5th ed.): Brisbane, Australia, Watermark Numerical Computing, accessed June 28, 2010, at http://www.pesthomepage.org/files/pestman.pdf.

Doherty, J.E., and Hunt, R.J., 2010, Approaches to highly parameterized inversion-A guide to using PEST for groundwater-model calibration: U.S. Geological Survey Scientific Investigations Report 2010-5169, 59 p., accessed June 28, 2010, at http://pubs.usgs.gov/sir/2010/5169/.
Doherty, J.E., Fienen, M.N., and Hunt, R.J., 2010, Approaches to highly parameterized inversion-Pilot-point theory, guidelines, and research directions: U.S. Geological Survey Scientific Investigations Report 2010-5168, 36 p., accessed June 28, 2010, at http://pubs.usgs.gov/sir/2010/5168/.

Dunlap, L.E., and Spinazola, J.M., 1984, Interpolating water-table altitudes in west-central Kansas using kriging techniques: U.S. Geological Survey Water-Supply Paper 2238, 19 p., accessed July 8, 2010, at http://pubs.usgs.gov/ wsp/2238/report.pdf.

Ellis, M.J., Ficken, J.H., and Adolphson, D.G., 1971, Hydrology of the Rosebud Indian Reservation, South Dakota: U.S. Geological Survey Hydrologic Investigations Atlas HA-335, 2 sheets, scale 1:100,000.

Esri, 2011a, An overview of the Geostatistical Analyst toolbar and toolbox: Redlands, Calif., Esri ArcGIS 10.0 help, accessed May 15, 2011, at http:// help.arcgis.com/en/arcgisdesktop/10.0/help/index. html\#//003000000002000000.htm.

Esri, 2011b, How kriging works: Redlands, Calif., Esri ArcGIS 10.0 help, accessed May 15, 2011, at http:// help.arcgis.com/en/arcgisdesktop/10.0/help/index. html\#//009z00000076000000.htm.

Esri, 2011c, Mapping and visualization in ArcGIS Desktop: Redlands, Calif., Esri ArcGIS 10.0 help, accessed July 11, 2010, at http://help.arcgis.com/en/arcgisdesktop/10.0/help/ index.html\#//00660000042t000000.

Farnsworth, R.K., Thompson, E.S., and Peck, E.L., 1982, Evaporation atlas for the contiguous 48 United States: National Oceanic and Atmospheric Administration Technical Report NWS 33, 26 p. (Also available at $h t t p: / / w w w$. nws.noaa.gov/oh/hdsc/PMP_related_studies/TR33.pdf.)

Fenneman, N.M., 1946, Physical divisions of the United States: U.S. Geological Survey, scale 1:7,000,000 (reprinted 1964).

Filipovic, Dragan, 2004, Hydrogeologic assessment of the High Plains aquifer in Gregory and Tripp Counties, South Dakota: South Dakota Geological Survey Open File Report 90-UR, 1 sheet, scale 1:100,000. (Also available at $h t t p: / /$ www.sdgs.usd.edu/pubs/pdf/UR-90_20040630.pdf.)

Freeze, R.A., and Cherry, J.A., 1979, Groundwater: Englewood Cliffs, N.J., Prentice-Hall, Inc., 604 p.

Gutentag, E.D., Heimes, F.J., Krothe, N.C., Luckey, R.R., and Weeks, J.B., 1984, Geohydrology of the High Plains aquifer in parts of Colorado, Kansas, Nebraska, New Mexico, Oklahoma, South Dakota, Texas, and Wyoming: U.S. Geological Survey Professional Paper 1400-B, 63 p. (Also available at http://pubs.usgs.gov/pp/1400b/report.pdf.) 
Hammond, P.D., 1996, Hydrogeologic investigation of the Herrick Formation near the city of Herrick, South Dakota: South Dakota Geological Survey Open-File Report 75-UR, 31 p. (Also available at $h t t p: / / w w w . s d g s . u s d . e d u / p u b s / p d f /$ UR-75.pdf.)

Harbaugh, A.W., 2005, MODFLOW-2005, the U.S. Geological Survey modular ground-water model-The groundwater flow process: U.S. Geological Survey Techniques and Methods, book 6, chap. A16, variously paged, accessed June 28, 2010, at http://pubs.usgs.gov/tm/2005/tm6A16/.

Hargreaves, G.H., and Samani, Z.A., 1985, Reference crop evapotranspiration from temperature: Applied Engineering in Agriculture, v. 1, no. 2, p. 96-99.

Harksen, J.C., and McDonald, J.R., 1969, Guidebook to the major Cenozoic deposits of southwestern South Dakota: South Dakota Geological Survey Guidebook, v. 2, 103 p.

Helsel, D.R. and R. M. Hirsch, 2002, Statistical Methods in Water Resources, U.S. Geological Survey Techniques of Water Resources Investigations, Book 4, chapter A3, 522 p. (Also available at $h t t p: / / p u b s . u s g s . g o v / t w r i / t w r i 4 a 3 / p d f /$ twri4a3-new.pdf.)

High Plains Regional Climate Center, 2011, Historical climate data summaries: Lincoln, Nebraska, University of Nebraska, accessed September 30, 2011, at http://www. hprcc.unl.edu/data/historical/.

Kolm, K.E., and Case, H.L., III, 1983, A two-dimensional, finite-difference model of the High Plains aquifer in southern South Dakota: U.S. Geological Survey Water-Resources Investigations Report 83-4175, 34 p. (Also available at http://pubs.usgs.gov/wri/1983/4175/report.pdf.)

Kremin-Smith, D.J., 1984, Hydrogeology of a portion of the Ogallala aquifer, south-central Todd County, South Dakota: Rapid City, South Dakota School of Mines and Technology M.S. thesis, $76 \mathrm{p}$.

LaBelle, Anneka, 2011, Using Thornthwaite-Mather soil-water balance method to estimate current and future recharge trends near Pine Ridge Reservation, South Dakota: Rapid City, South Dakota School of Mines and Technology M.S. thesis, $79 \mathrm{p}$.

Langbein, W.B. and others, 1949, Annual runoff in the United States: U.S. Geological Survey Circular 52, 14 p., 1 pl., scale 1:8,740,000. (Also available at http://pubs.usgs.gov/ circ/1949/0052/report.pdf.)

Long, A.J., and Putnam, L.D., 2010, Simulated groundwater flow in the Ogallala and Arikaree aquifers, Rosebud Indian Reservation area, South Dakota-Revisions with data through water year 2008 and simulations of potential future scenarios: U.S. Geological Survey Scientific Investigations Report 2010-5105, 64 p., accessed September 30, 2011, at http://pubs.usgs.gov/sir/2010/5105/.
Long, A.J., Putnam, L.D., and Carter, J.M., 2003, Simulated ground-water flow in the Ogallala and Arikaree aquifers, Rosebud Indian Reservation area, South Dakota: U.S. Geological Survey Water-Resources Investigations Report 03-4043, 69 p. (Also available at http://pubs.usgs.gov/wri/ wri034043/wri034043.html.)

Luckey, R.R., Gutentag, E.D., Heimes, F.J., and Weeks, J.B., 1986, Digital simulation of ground-water flow in the High Plains aquifer in parts of Colorado, Kansas, Nebraska, New Mexico, Oklahoma, South Dakota, Texas, and Wyoming: U.S. Geological Survey Professional Paper 1400-D, 57 p. (Also available at $h t t p: / / p u b s . u s g s . g o v / p p / 1400 d /$ report. $p d f$.)

Luckey, R.R., Gutentag, E.D., Heimes, F.J., and Weeks, J.B., 1988, Effects of future ground-water pumpage on the High Plains aquifer in parts of Colorado, Kansas, Nebraska, New Mexico, Oklahoma, South Dakota, Texas, and Wyoming: U.S. Geological Survey Professional Paper 1400-E, 44 p. (Also available at $h t t p: / / p u b s . u s g s . g o v / p p / 1400 e /$ report.pdf.)

Mace, R.E., 2001, Estimating transmissivity using specificcapacity data: Austin, Texas, University of Texas at Austin, Bureau of Economic Geology Geological Circular 01-2, $44 \mathrm{p}$.

Martin, J.E., Sawyer, J.F., Fahrenbach, M.D., Tomhave, D.W., and Schulz, L.D., 2004, Geologic map of South Dakota: South Dakota Geological Survey General Map G-10, 1 sheet, scale 1:500,000, $20 \mathrm{p}$. reference pamphlet. (Also available at $h t t p: / / w w w . s d g s . u s d . e d u / p u b l i c a t i o n s / g e n e r a l$. html.)

McCormick, K.A., 2010, Elevation contour map of the Precambrian surface of South Dakota: South Dakota Geological Survey General Map G-11, scale 1:500,000. (Also available at $h t t p: / / w w w . s d g s . u s d . e d u / p u b s / p d f / G-11 \% 20-\% 20$ statewide\%20map.pdf.)

McDonald, M.G., and Harbaugh, A.W., 1988, A modular three-dimensional finite-difference ground-water flow model: U.S. Geological Survey Techniques of WaterResources Investigations, book 6, chap. A1, variously paged. (Also available at http://pubs.usgs.gov/twri/ twri6al/.)

McGuire, V.L., 2001, Water-level changes in the High Plains aquifer, 1980 to 1999: U.S. Geological Survey Fact Sheet 2001-029, 2 p. (Also available at http://pubs.usgs.gov/ $f_{s} / 2001 / f_{s-029-01 / .)}$

McMahon, P.B., Dennehy, K.F., Bruce, B.W., Gurdak, J.J., and Qi, S.L., 2007, Water-quality assessment of the High Plains aquifer, 1999-2004: U.S. Geological Survey Professional Paper 1749, 136 p. (Also available at http://pubs.usgs.gov/ pp/1749/.) 
Multi-Resolution Land Characteristics Consortium, 2009, National land cover database 2001: U.S. Geological Survey, accessed October 26, 2010, at http://www.mrlc.gov/nlcd. php.

National Oceanic and Atmospheric Administration, 2010, NOAA satellite and information service: National Oceanic and Atmospheric Administration, accessed August 8, 2010, at http://www.ncdc.noaa.gov/oa/climate/stationlocator.html.

Natural Resources Conservation Service, 2009a, Physical soil properties - Tripp County, South Dakota, tabular data version 13: U.S. Department of Agriculture, Natural Resources Conservation Service, 25 p., accessed January 12, 2011, at http://soildatamart.nrcs.usda.gov/State.aspx?State $=S D$.

Natural Resources Conservation Service, 2009b, Water features - Tripp County, South Dakota, tabular data version 13: U.S. Department of Agriculture, Natural Resources Conservation Service, 19 p., accessed January 12, 2011, at http:// soildatamart.nrcs.usda.gov/State.aspx? State $=S D$.

Newport, T.G., 1959, Ground-water resources of the lower Niobrara River and Ponca Creek Basins, Nebraska and South Dakota, with a section on Chemical quality of the water, by R.A. Krieger: U.S. Geological Survey WaterSupply Paper 1460-G, p. 272-323. (Also available at http:// pubs.usgs.gov/wsp/1460g/report.pdf.)

Niswonger, R.G., Panday, Sorab, and Ibaraki, Motomu, 2011, MODFLOW-NWT, a Newton formulation for MODFLOW-2005: U.S. Geological Survey Techniques and Methods 6-A37, 44 p., accessed May 17, 2011, at http:// pubs.usgs.gov/tm/tm6a37/.

Qi, S.L., 2010, Digital map of the aquifer boundary of the High Plains aquifer in parts of Colorado, Kansas, Nebraska, New Mexico, Oklahoma, South Dakota, Texas, and Wyoming: U.S. Geological Survey Data Series 543, accessed May 15, 2011, at http://pubs.usgs.gov/ds/543/.

Rahn, P.H., and Paul, H.A., 1975, Hydrogeology of a portion of the Sand Hills and Ogallala aquifer, South Dakota and Nebraska: Ground Water, v. 13, no. 5, p. 428-437.

Rutledge, A.T., 1998, Computer programs for describing the recession of ground-water discharge and for estimating mean ground-water recharge and discharge from streamflow records-Update: U.S. Geological Survey Water-Resources Investigations Report 98-4148, 43 p., accessed December 29, 2011, at http://pubs.usgs.gov/wri/wri984148/.

Sevon, W.D., and Petsch, B.C., 1960, Geology of the Spring Creek quadrangle, South Dakota: South Dakota Geological Survey Geologic Quadrangle GQ62K-092, scale 1:62,500, 2 sheets. (Also available at http://www.sdgs.usd.edu/pubs/ $p d f / G Q 62 K-092 . p d f$.)
South Dakota Department of Environment and Natural Resources, 2010, Lithologic logs database: South Dakota Geological Survey, accessed July 15, 2010, at http://sddenr. net/lithdb/.

South Dakota Department of Environment and Natural Resources, 2011, South Dakota water rights database: South Dakota Department of Environment and Natural Resources, accessed November 30, 2011, at http://denr.sd.gov/des/wr/ dbwrsearch.aspx.

South Dakota State University, 2011, Frost dates for coop stations: South Dakota State University, accessed January 20, 2010, at http://climate.sdstate.edu/w_info/frost/frost.shtm.

Springer, R.F., 1979, Soil survey of Tripp County, South Dakota: U.S. Department of Agriculture Soil Conservation Service and Bureau of Indian Affairs, 197 p. plus guide to mapping units. (Also available at $h t t p: / / s o i l s . u s d a . g o v /$ survey/online_surveys/south_dakota/SD123/tripp.pdf.)

Stanton, J.S., Qi, S.L., Ryter, D.W., Falk, S.E., Houston, N.A., Peterson, S.M., Westenbroek, S.M., and Christenson, S.C., 2011, Selected approaches to estimate water-budget components of the High Plains, 1940 through 1949 and 2000 through 2009: U.S. Geological Survey Scientific Investigations Report 2011-5183, 79 p., accessed July 12, 2012, at http://pubs.usgs.gov/sir/2011/5183/.

Stevenson, R.E., and Buckmeier, F.J., 1958, Geology of the Gregory quadrangle, South Dakota: South Dakota Geological Survey Geologic Quadrangle GQ62K-066, scale 1:62,500, 2 sheets. (Also available at $h t t p: / / w w w . s d g s . u s d$. edu/pubs/pdf/GQ62K-066.pdf.)

Theis, C.V., Brown, R.H., and Meyer, R.R., 1963, Estimating the transmissibility of aquifers from the specific capacity of wells, in Bentall, Ray, comp., Methods of determining permeability, transmissivity, and drawdown: U.S. Geological Survey Water-Supply Paper 1536-I, p. 331-340. (Also available at $h t t p: / / p u b s . e r . u s g s . g o v / p u b l i c a t i o n / w s p 1536 I$.)

Thelin, G.P., and Heimes, F.J., 1987, Mapping irrigated cropland from Landsat data for determination of water use from the High Plains aquifer in parts of Colorado, Kansas, Nebraska, New Mexico, Oklahoma, South Dakota, Texas, and Wyoming: U.S. Geological Survey Professional Paper 1400-C, 38 p., 1 plate. (Also available at http://pubs.usgs. gov/pp/1400c/.)

Thornthwaite, C.W., 1948, An approach toward a rational classification of climate: Geographical Review, v. 38, no. 1, p. 55-94. (Also available at http://www.jstor.org/ sici? sici $=0016-7428 \% 28194801 \% 2938 \% 3 \mathrm{A1} \% 3 \mathrm{C55} \% 3 \mathrm{AA}$ ATARC\%3E2.0.CO\%3B2-O.) 
Thornthwaite, C.W., and Mather, J.R., 1957, Instructions and tables for computing potential evapotranspiration and the water balance: Centerton, N.J., Drexel Institute of Technology, Laboratory of Climatology Publications in Climatology, v. 10, no. 3, p. 183-311.

Tripp County Water User District, 2012, History: Tripp County Water User District, accessed January 27, 2012, at http://trippcountywater.com/?page_id $=179$.

U.S. Census Bureau, 2002, South Dakota-2000-Summary population and housing characteristics: U.S. Census Bureau 2000 Census of Population and Housing PHC-1-43, November, 351 p., accessed December 10, 2011, at http:// www.census.gov/prod/cen2000/phc-1-43.pdf.

U.S. Geological Survey, 2006, National elevation dataset: U.S. Geological Survey, accessed May 12, 2010, at http://ned. usgs.gov/.

U.S. Geological Survey, 2009, Water use in the United States: U.S. Geological Survey database, accessed March 17, 2011, at http://water.usgs.gov/watuse/.

U.S. Geological Survey, 2011, USGS water data for South Dakota: U.S. Geological Survey National Water Information System, accessed June 28, 2011, at http://waterdata. usgs.gov/sd/nwis/.

University of Nebraska-Lincoln, 2010, Bedrock geology of Nebraska: Lincoln, University of Nebraska-Lincoln GIS geology database, accessed July 12, 2012, at http://snr.unl. edu/data/geographygis/NebrGISgeology.asp\#bedrock.
Weeks, J.B., and Gutentag, E.D., 1981, Bedrock geology, altitude of base, and 1980 saturated thickness of the High Plains aquifer in parts of Colorado, Kansas, Nebraska, New Mexico, Oklahoma, South Dakota, Texas, and Wyoming: U.S. Geological Survey Hydrologic Investigations Atlas HA-648, 2 plates.

Weeks, J.B., Gutentag, E.D., Heimes, F.J., and Luckey, R.R., 1988, Summary of the High Plains regional aquifer-system analysis in parts of Colorado, Kansas, Nebraska, New Mexico, Oklahoma, South Dakota, Texas, and Wyoming: U.S. Geological Survey Professional Paper 1400-A, 30 p. (Also available at http://pubs.usgs.gov/pp/1400a/.)

Westenbroek, S.M., Kelson, V.A., Dripps, W.R., Hunt, R.J., and Bradbury, K.R., 2010, SWB-A modified Thornthwaite-Mather soil-water-balance code for estimating groundwater recharge: U.S. Geological Survey Techniques and Methods, book 6, chap. A31, 60 p., accessed June 28, 2011, at http://pubs.usgs.gov/tm/tm6-a31/.

Wiesner, C.H., 1984, Soil survey of Gregory County, South Dakota: U.S. Department of Agriculture, 175 p.

Wilson, W.E., and Moore, J.E., eds., 1998, Glossary of hydrology: Alexandria, Virginia, American Geological Institute, 248 p. 

Supplemental Information 


\section{Supplement 1. Data Used to Estimate Mean Potentiometric Surface}

Data for all wells used to estimate the mean potentiometric surface of the Ogallala aquifer for water years 1985 through 2009 are presented in table S1-1.

Table S1-1. Selected data from wells used for mean potentiometric surface of the Ogallala aquifer for water years $1985-2009$.

[NGVD 29, National Geodetic Vertical Datum of 1929; --, not available]

\begin{tabular}{|c|c|c|c|c|c|c|c|c|}
\hline $\begin{array}{l}\text { Index } \\
\text { num- } \\
\text { ber } \\
\text { (fig. 6) }\end{array}$ & $\begin{array}{c}\text { Site identification } \\
\text { number }\end{array}$ & Legal location & $\begin{array}{c}\text { Land- } \\
\text { surface } \\
\text { altitude } \\
\text { (feet above } \\
\text { NGVD 29) }\end{array}$ & $\begin{array}{l}\text { Well } \\
\text { depth }\end{array}$ & $\begin{array}{l}\text { Hydraulic head } \\
\text { measurement date or } \\
\text { range of dates }\end{array}$ & $\begin{array}{c}\text { Number } \\
\text { of mea- } \\
\text { sure- } \\
\text { ments }\end{array}$ & $\begin{array}{c}\text { Mean } \\
\text { measured } \\
\text { hydraulic } \\
\text { head } \\
\text { (feet above } \\
\text { NGVD 29) }\end{array}$ & $\begin{array}{c}\text { Other } \\
\text { identifier }\end{array}$ \\
\hline 1 & 425923099134101 & 35N16W20DC & 2,153 & 136 & $5 / 30 / 2009$ & 1 & 2,119 & -- \\
\hline 2 & 425902099085501 & $35 \mathrm{~N} 16 \mathrm{~W} 25 \mathrm{AB}$ & 2,111 & 134 & $10 / 12 / 2006$ & 1 & 2,066 & -- \\
\hline 3 & 425913099330401 & $35 \mathrm{~N} 19 \mathrm{~W} 28 \mathrm{AA}$ & 1,983 & 15 & $10 / 27 / 2000$ & 1 & 1,974 & -- \\
\hline 4 & 425944099521201 & $35 \mathrm{~N} 22 \mathrm{~W} 23 \mathrm{AA}$ & 2,360 & 90 & $6 / 14 / 2007$ & 1 & 2,349 & -- \\
\hline 5 & 425939099513501 & $35 \mathrm{~N} 22 \mathrm{~W} 24 \mathrm{BA}$ & 2,370 & 60 & $9 / 14 / 2001$ & 1 & 2,347 & -- \\
\hline 6 & 425856099530201 & $35 \mathrm{~N} 22 \mathrm{~W} 26 \mathrm{BB}$ & 2,424 & 140 & $7 / 16 / 1996$ & 1 & 2,339 & -- \\
\hline 7 & 425932099580401 & $35 \mathrm{~N} 23 \mathrm{~W} 24 \mathrm{AD}$ & 2,474 & 105 & 7/5/1999 & 1 & 2,426 & -- \\
\hline 8 & 425924099583801 & $35 \mathrm{~N} 23 \mathrm{~W} 24 \mathrm{CA}$ & 2,471 & 118 & $4 / 18 / 2000$ & 1 & 2,399 & -- \\
\hline 9 & 425937100095901 & $35 \mathrm{~N} 24 \mathrm{~W} 20 \mathrm{AC}$ & 2,549 & 120 & 9/3/1994 & 1 & 2,499 & -- \\
\hline 10 & 425919100092901 & $35 \mathrm{~N} 24 \mathrm{~W} 21 \mathrm{DA}$ & 2,561 & 146 & 9/3/1994 & 1 & 2,508 & -- \\
\hline 11 & 425846100113601 & $35 \mathrm{~N} 24 \mathrm{~W} 30 \mathrm{BC}$ & 2,515 & 80 & $8 / 9 / 2002$ & 1 & 2,503 & -- \\
\hline 12 & 430422098565001 & 95N69W 1BB 1 & 1,955 & 66 & $4 / 22 / 1998$ & 1 & 1,945 & -- \\
\hline 13 & 430405098563401 & 95N69W 1DDDD & 1,930 & 64 & $11 / 13 / 1984-9 / 30 / 2009$ & 174 & $1,897.7$ & GY-78C \\
\hline 14 & 430416098580901 & 95N69W 2DC & 1,970 & 70 & $12 / 30 / 1992$ & 1 & 1,947 & -- \\
\hline 15 & 430435099004001 & $95 \mathrm{~N} 69 \mathrm{~W} 4$ & 2,025 & 50 & $6 / 14 / 1985$ & 1 & 1,998 & -- \\
\hline 16 & 430403098580901 & $95 \mathrm{~N} 69 \mathrm{~W} 11 \mathrm{AB}$ & 1,961 & 60 & $7 / 16 / 1996$ & 1 & 1,947 & -- \\
\hline 17 & 430344098570701 & $95 \mathrm{~N} 69 \mathrm{~W} 12 \mathrm{CA}$ & 1,921 & 74 & $12 / 28 / 1984$ & 1 & 1,909 & -- \\
\hline 18 & 430310098574401 & 95N69W14AAAA & 1,943 & 83 & $11 / 13 / 1984-9 / 30 / 2009$ & 173 & $1,909.7$ & GY-78D \\
\hline 19 & 430350099054901 & 95N70W11BC & 2,069 & 37 & $12 / 16 / 2004$ & 1 & 2,049 & -- \\
\hline 20 & 430403099201001 & 95N72W10AAAA & 2,161 & -- & $6 / 11 / 2003$ & 1 & 2,153 & R2-2003-28 \\
\hline 21 & 430128099234101 & 95N72W20CCCC & 2,285 & 133 & $7 / 22 / 2003$ & 1 & 2,188 & $\mathrm{R} 2-2003-27^{\mathrm{a}}$ \\
\hline 22 & 430129099201201 & 95N72W22DDDD & 2,217 & 104 & $11 / 13 / 1984-9 / 30 / 2009$ & 174 & $2,182.7$ & $\mathrm{GY}-78 \mathrm{~B}$ \\
\hline 23 & 430203099193401 & $95 \mathrm{~N} 72 \mathrm{~W} 23 \mathrm{CD}$ & 2,193 & 94 & $2 / 25 / 1986$ & 1 & 2,163 & -- \\
\hline 24 & 430118099201901 & $95 \mathrm{~N} 72 \mathrm{~W} 27 \mathrm{AD}$ & 2,233 & 144 & $8 / 28 / 1993$ & 1 & 2,178 & -- \\
\hline 25 & 430144099194302 & $95 \mathrm{~N} 72 \mathrm{~W} 32 \mathrm{CD} 3$ & 2,223 & -- & 7/8/1993 & 1 & 2,193 & -- \\
\hline 26 & 430028099181401 & 95N72W36AC & 2,225 & 60 & $5 / 11 / 1995$ & 1 & 2,205 & -- \\
\hline 27 & 430404099282801 & 95N73W 4DDDD & 2,305 & -- & $6 / 10 / 2003$ & 1 & 2,258 & R2-2000-25 \\
\hline 28 & 430441099365401 & 95N74W 5BD & 2,309 & 60 & $5 / 25 / 2004$ & 1 & 2,297 & -- \\
\hline 29 & 425946099382001 & 95N74W31DDCC 1 & 1,990 & 30 & $11 / 14 / 1984-9 / 30 / 2009$ & 119 & $1,963.1$ & $\mathrm{TR}-57 \mathrm{C}$ \\
\hline 30 & 430454099482801 & 95N76W 2BB & 2,304 & 62 & $6 / 17 / 1992$ & 1 & 2,290 & -- \\
\hline
\end{tabular}


Table S1-1. Selected data from wells used for mean potentiometric surface of the Ogallala aquifer for water years 1985-2009.-Continued [NGVD 29, National Geodetic Vertical Datum of 1929; --, not available]

\begin{tabular}{|c|c|c|c|c|c|c|c|c|}
\hline $\begin{array}{l}\text { Index } \\
\text { num- } \\
\text { ber } \\
\text { (fig. 6) }\end{array}$ & $\begin{array}{c}\text { Site identification } \\
\text { number }\end{array}$ & Legal location & $\begin{array}{c}\text { Land- } \\
\text { surface } \\
\text { altitude } \\
\text { (feet above } \\
\text { NGVD 29) }\end{array}$ & $\begin{array}{l}\text { Well } \\
\text { depth }\end{array}$ & $\begin{array}{l}\text { Hydraulic head } \\
\text { measurement date or } \\
\text { range of dates }\end{array}$ & $\begin{array}{c}\text { Number } \\
\text { of mea- } \\
\text { sure- } \\
\text { ments }\end{array}$ & $\begin{array}{c}\text { Mean } \\
\text { measured } \\
\text { hydraulic } \\
\text { head } \\
\text { (feet above } \\
\text { NGVD 29) }\end{array}$ & $\begin{array}{c}\text { Other } \\
\text { identifier }\end{array}$ \\
\hline 31 & 430454099495701 & 95N76W 4AA & 2,297 & 38 & $5 / 1 / 2001$ & 1 & 2,277 & -- \\
\hline 32 & 430215099522801 & $95 \mathrm{~N} 76 \mathrm{~W} 19 \mathrm{~A}$ & 2,203 & 90 & $4 / 17 / 1993$ & 1 & 2,173 & -- \\
\hline 33 & 430035099465201 & 95N76W25CDDD & 2,138 & -- & $5 / 18 / 1999$ & 1 & 2,100 & R2-99-02 \\
\hline 34 & 430053099505001 & 95N76W28CC & 2,318 & 55 & $7 / 13 / 2000$ & 1 & 2,290 & -- \\
\hline 35 & 430128099520001 & 95N76W29BBBB & 2,253 & 77 & 11/14/1984-9/30/2009 & 172 & $2,222.4$ & $\mathrm{TR}-78 \mathrm{~F}$ \\
\hline 36 & 425956099520501 & 95N76W32CCCC & 2,348 & 66 & $11 / 14 / 1984-9 / 30 / 2009$ & 173 & $2,337.8$ & $\mathrm{TR}-78 \mathrm{~N}$ \\
\hline 37 & 430002099501501 & 95N76W33DC & 2,262 & 45 & $12 / 5 / 1996$ & 1 & 2,250 & -- \\
\hline 38 & 430429099575701 & $95 \mathrm{~N} 77 \mathrm{~W} 4 \mathrm{CB}$ & 2,204 & 55 & 9/5/1991 & 1 & 2,163 & -- \\
\hline 39 & 430312099554501 & 95N77W14BBBB & 2,214 & 50 & $3 / 11 / 2002-8 / 7 / 2003$ & 4 & 2,175 & $\mathrm{R} 2-2001-60^{\mathrm{a}}$ \\
\hline 40 & 430235099592601 & 95N77W18DD & 2,311 & 80 & 4/1/1998 & 1 & 2,297 & -- \\
\hline 41 & 430144099592601 & 95N77W19DD 1 & 2,326 & 60 & $10 / 2 / 2000$ & 1 & 2,318 & -- \\
\hline 42 & 430144099592602 & 95N77W19DD 2 & 2,326 & -- & $5 / 14 / 2001$ & 1 & 2,318 & -- \\
\hline 43 & 430037099535601 & 95N77W25DCCC & 2,288 & 185 & $11 / 14 / 1984-9 / 30 / 2009$ & 165 & $2,244.9$ & $\mathrm{TR}-78 \mathrm{M}$ \\
\hline 44 & 430053099551601 & 95N77W26CD & 2,289 & 98 & $3 / 8 / 1994$ & 1 & 2,278 & -- \\
\hline 45 & 430106099562801 & 95N77W27CA & 2,353 & 130 & $8 / 15 / 2006$ & 1 & 2,334 & -- \\
\hline 46 & 430043099584601 & 95N77W29CD & 2,289 & 60 & $8 / 16 / 2006$ & 1 & 2,277 & -- \\
\hline 47 & 430100100001001 & 95N77W30C & 2,340 & 58 & $2 / 25 / 1991$ & 1 & 2,329 & -- \\
\hline 48 & 430010099580601 & 95N77W32CAAD & 2,380 & 76 & 11/14/1984-9/30/2009 & 170 & $2,342.3$ & TR-59B \\
\hline 49 & 430332100012201 & $95 \mathrm{~N} 78 \mathrm{~W} 12 \mathrm{C}$ & 2,332 & 130 & 9/15/1994 & 1 & 2,292 & -- \\
\hline 50 & 430248100014801 & 95N78W14DB & 2,342 & 120 & 9/14/1994 & 1 & 2,312 & -- \\
\hline 51 & 430133100061501 & 95N78W20CCCC & 2,430 & 105 & $11 / 14 / 1984-9 / 30 / 2009$ & 174 & $2,388.3$ & TR-78E \\
\hline 52 & 430131100063401 & 95N78W30AA & 2,432 & -- & 7/19/1991 & 1 & 2,378 & -- \\
\hline 53 & 430015100061601 & 95N78W32DC & 2,421 & 100 & 9/23/1988 & 1 & 2,405 & -- \\
\hline 54 & 430035100040401 & 95N78W33AAAA & 2,426 & -- & 6/8/1999 & 1 & 2,400 & R20-99-16 ${ }^{\mathrm{a}}$ \\
\hline 55 & 430003100022401 & 95N78W35CD & 2,451 & 90 & $8 / 14 / 1986$ & 1 & 2,391 & -- \\
\hline 56 & 430003100014801 & 95N78W35DD & 2,402 & 60 & $12 / 7 / 2000$ & 1 & 2,382 & -- \\
\hline 57 & 430131100091401 & $95 \mathrm{~N} 79 \mathrm{~W} 26 \mathrm{AB}$ & 2,480 & 100 & $9 / 19 / 2001$ & 1 & 2,423 & -- \\
\hline 58 & 430053100121201 & 95N79W28CC & 2,431 & 90 & $7 / 30 / 1993$ & 1 & 2,427 & -- \\
\hline 59 & 430035100111001 & 95N79W33AAAA & 2,500 & -- & $7 / 20 / 1999$ & 1 & 2,414 & R20-99-40 \\
\hline 60 & 430856099014201 & 96N69W 8AC & 2,041 & 80 & 11/10/1990 & 1 & 2,013 & -- \\
\hline 61 & 430804099042101 & 96N70W13BD & 2,104 & 70 & $8 / 25 / 1994$ & 1 & 2,079 & -- \\
\hline 62 & 430738099053101 & 96N70W14CD 1 & 2,122 & 74 & 9/16/1989 & 1 & 2,072 & -- \\
\hline 63 & 430758099074401 & 96N70W16BD & 2,140 & 50 & 8/11/1997 & 1 & 2,131 & -- \\
\hline 64 & 430621099060701 & 96N70W27AD & 2,103 & 60 & $3 / 23 / 1994$ & 1 & 2,081 & -- \\
\hline 65 & 430635099085501 & 96N70W29BB 1 & 2,140 & 45 & $12 / 20 / 1984$ & 1 & 2,112 & -- \\
\hline
\end{tabular}


Table S1-1. Selected data from wells used for mean potentiometric surface of the Ogallala aquifer for water years 1985-2009.-Continued [NGVD 29, National Geodetic Vertical Datum of 1929; --, not available]

\begin{tabular}{|c|c|c|c|c|c|c|c|c|}
\hline $\begin{array}{l}\text { Index } \\
\text { num- } \\
\text { ber } \\
\text { (fig. 6) }\end{array}$ & $\begin{array}{c}\text { Site identification } \\
\text { number }\end{array}$ & Legal location & $\begin{array}{l}\text { Land- } \\
\text { surface } \\
\text { altitude } \\
\text { (feet above } \\
\text { NGVD 29) }\end{array}$ & $\begin{array}{l}\text { Well } \\
\text { depth }\end{array}$ & $\begin{array}{l}\text { Hydraulic head } \\
\text { measurement date or } \\
\text { range of dates }\end{array}$ & $\begin{array}{l}\text { Number } \\
\text { of mea- } \\
\text { sure- } \\
\text { ments }\end{array}$ & $\begin{array}{c}\text { Mean } \\
\text { measured } \\
\text { hydraulic } \\
\text { head } \\
\text { (feet above } \\
\text { NGVD 29) }\end{array}$ & $\begin{array}{c}\text { Other } \\
\text { identifier }\end{array}$ \\
\hline 66 & 430537099104001 & 96N70W31BBCC 1 & 2,155 & 74 & $6 / 27 / 1990$ & 1 & 2,107 & R20-90-26 \\
\hline 67 & 430543099071801 & 96N70W33AA & 2,147 & 80 & 3/1/1999 & 1 & 2,091 & -- \\
\hline 68 & 430542099055901 & 96N70W34AAAD & 2,085 & 16 & 11/13/1984-9/30/2009 & 175 & $2,080.0$ & GY-57B \\
\hline 69 & 430457099060001 & 96N70W34DDDD & 2,077 & -- & $6 / 17 / 2003$ & 1 & 2,064 & R2-2003-36 \\
\hline 70 & 430947099140501 & 96N71W 3BC & 2,140 & 60 & $9 / 22 / 2001$ & 1 & 2,092 & -- \\
\hline 71 & 431006099163801 & 96N71W 6AAAA & 2,165 & 123 & 11/13/1984-9/30/2009 & 173 & $2,112.9$ & GY-78A \\
\hline 72 & 430923099174601 & $96 \mathrm{~N} 71 \mathrm{~W} 6 \mathrm{CCCB}$ & 2,092 & -- & $7 / 19 / 1994$ & 1 & 2,084 & R20-94-42 \\
\hline 73 & 430830099164501 & 96N71W 7DD & 2,159 & 70 & 9/16/1991 & 1 & 2,152 & -- \\
\hline 74 & 430743099115001 & 96N71W13CCBB & 2,163 & 39 & 11/13/1984-9/30/2009 & 174 & $2,138.5$ & GY-57A \\
\hline 75 & 430758099122701 & $96 \mathrm{~N} 71 \mathrm{~W} 14 \mathrm{AC} 2$ & 2,172 & 73 & $11 / 18 / 1984$ & 1 & 2,134 & -- \\
\hline 76 & 430621099125401 & 96N71W26BC & 2,173 & 70 & 9/18/1991 & 1 & 2,166 & -- \\
\hline 77 & 430530099105001 & 96N71W36AD & 2,120 & 48 & $9 / 18 / 2000$ & 1 & 2,100 & -- \\
\hline 78 & 430556099305901 & 96N73W30DD & 2,284 & 60 & $5 / 15 / 1990$ & 1 & 2,279 & -- \\
\hline 79 & 430505099304901 & $96 \mathrm{~N} 73 \mathrm{~W} 32 \mathrm{CCBB}$ & 2,310 & -- & $6 / 6 / 2000$ & 1 & 2,280 & R2-2000-08 \\
\hline 80 & 430921099332101 & 96N74W 2DD & 2,291 & 70 & $3 / 31 / 1991$ & 1 & 2,281 & -- \\
\hline 81 & 431008099375501 & $96 \mathrm{~N} 74 \mathrm{~W}$ 5BBBB & 2,275 & -- & $6 / 25 / 2001$ & 1 & 2,245 & R20-2001-18 \\
\hline 82 & 430823099353501 & 96N74W16AAAA & 2,325 & -- & $10 / 2 / 2001$ & 1 & 2,300 & R2-2001-59 \\
\hline 83 & 430732099353201 & 96N74W16DDDD & 2,342 & 35 & 11/13/1984-9/30/2009 & 169 & $2,334.8$ & TR-79A \\
\hline 84 & 430725099341401 & 96N74W23BB & 2,290 & 48 & $11 / 17 / 1984$ & 1 & 2,278 & -- \\
\hline 85 & 430555099330301 & 96N74W25CC & 2,331 & 50 & $9 / 26 / 1990$ & 1 & 2,318 & -- \\
\hline 86 & 430608099345001 & 96N74W27DB 1 & 2,325 & 36 & 9/29/1999 & 1 & 2,317 & -- \\
\hline 87 & 430923099461001 & 96N75W 6CCCC & 2,301 & 30 & 11/13/1984-9/30/2009 & 175 & $2,290.3$ & $\mathrm{TR}-78 \mathrm{~K}$ \\
\hline 88 & 430902099411201 & 96N75W11DA & 2,311 & 40 & $4 / 29 / 1998$ & 1 & 2,302 & -- \\
\hline 89 & 430647099410301 & $96 \mathrm{~N} 75 \mathrm{~W} 32 \mathrm{CD}$ & 2,340 & 46 & $5 / 5 / 1993$ & 1 & 2,325 & -- \\
\hline 90 & 430545099424001 & 96N75W34BBBB & 2,275 & -- & $6 / 20 / 2001$ & 1 & 2,261 & R20-2001-15 \\
\hline 91 & 430546099401701 & 96N75W36BBBB & 2,360 & -- & $5 / 19 / 1999$ & 1 & 2,307 & R20-99-04 \\
\hline 92 & 430947099473501 & 96N76W 2AD & 2,349 & 54 & $7 / 11 / 2002$ & 1 & 2,342 & -- \\
\hline 93 & 430921099482801 & 96N76W 2CC & 2,308 & 70 & 9/20/1989 & 1 & 2,296 & -- \\
\hline 94 & 431000099503301 & 96N76W 4BA & 2,310 & 52 & $11 / 18 / 2000$ & 1 & 2,285 & -- \\
\hline 95 & 431000099510801 & 96N76W 5AA & 2,310 & 60 & $11 / 4 / 1988$ & 1 & 2,304 & -- \\
\hline 96 & 431008099521001 & 96N76W 5BBBB & 2,306 & -- & $6 / 13 / 2001$ & 1 & 2,267 & R20-2001-13 \\
\hline 97 & 430919099521501 & 96N76W 6DDDD & 2,309 & 25 & 11/13/1984-9/30/2009 & 175 & $2,305.5$ & $\mathrm{TR}-78 \mathrm{~J}$ \\
\hline 98 & 430855099510801 & 96N76W 8AD & 2,291 & 60 & $11 / 8 / 1988$ & 1 & 2,283 & -- \\
\hline 99 & 430823099483601 & 96N76W14BBBB & 2,282 & -- & $10 / 2 / 2001$ & 1 & 2,260 & R2-2001-58 \\
\hline 100 & 430638099520801 & 96N76W29BBBB & 2,246 & 46 & 11/14/1984-9/30/2009 & 175 & $2,235.7$ & $\mathrm{TR}-78 \mathrm{~L}$ \\
\hline
\end{tabular}


Table S1-1. Selected data from wells used for mean potentiometric surface of the Ogallala aquifer for water years 1985-2009.-Continued [NGVD 29, National Geodetic Vertical Datum of 1929; --, not available]

\begin{tabular}{|c|c|c|c|c|c|c|c|c|}
\hline $\begin{array}{l}\text { Index } \\
\text { num- } \\
\text { ber } \\
\text { (fig. 6) }\end{array}$ & $\begin{array}{c}\text { Site identification } \\
\text { number }\end{array}$ & Legal location & $\begin{array}{l}\text { Land- } \\
\text { surface } \\
\text { altitude } \\
\text { (feet above } \\
\text { NGVD 29) }\end{array}$ & $\begin{array}{l}\text { Well } \\
\text { depth }\end{array}$ & $\begin{array}{l}\text { Hydraulic head } \\
\text { measurement date or } \\
\text { range of dates }\end{array}$ & $\begin{array}{c}\text { Number } \\
\text { of mea- } \\
\text { sure- } \\
\text { ments }\end{array}$ & $\begin{array}{c}\text { Mean } \\
\text { measured } \\
\text { hydraulic } \\
\text { head } \\
\text { (feet above } \\
\text { NGVD 29) }\end{array}$ & $\begin{array}{c}\text { Other } \\
\text { identifier }\end{array}$ \\
\hline 101 & 430530099525501 & 96N76W31BD & 2,198 & 40 & $11 / 8 / 2000$ & 1 & 2,186 & -- \\
\hline 102 & 430504099520101 & 96N76W32CC & 2,168 & 51 & $10 / 22 / 2003$ & 1 & 2,150 & -- \\
\hline 103 & 430543099484601 & 96N76W34AA & 2,290 & 50 & 7/7/1992 & 1 & 2,278 & -- \\
\hline 104 & 431008099543301 & $96 \mathrm{~N} 77 \mathrm{~W} 1 \mathrm{BBBB}$ & 2,317 & -- & $6 / 13 / 2001$ & 1 & 2,291 & R20-2001-10 \\
\hline 105 & 431008099580401 & 96N77W 4BBBB & 2,375 & 207 & 6/9/1999 & 1 & 2,303 & R20-99-18 \\
\hline 106 & 430856099570401 & 96N77W 9DC & 2,354 & 32 & 8/24/1989 & 1 & 2,340 & -- \\
\hline 107 & 430811099563701 & 96N77W15B & 2,307 & 47 & $8 / 27 / 2000$ & 1 & 2,299 & -- \\
\hline 108 & 430824099565501 & 96N77W15BBBB & 2,309 & -- & $10 / 31 / 2000$ & 1 & 2,294 & R2-2000-83 \\
\hline 109 & 430811100001001 & $96 \mathrm{~N} 77 \mathrm{~W} 18 \mathrm{~B}$ & 2,290 & 66 & $4 / 1 / 1996$ & 1 & 2,255 & -- \\
\hline 110 & 430726099542401 & 96N77W24BB & 2,301 & 24 & $10 / 10 / 2003$ & 1 & 2,291 & -- \\
\hline 111 & 430609099590801 & $96 \mathrm{~N} 77 \mathrm{~W} 29 \mathrm{CB}$ & 2,227 & 70 & 9/16/1992 & 1 & 2,204 & -- \\
\hline 112 & 430923100035301 & $96 \mathrm{~N} 78 \mathrm{~W} 3 \mathrm{CC}$ & 2,314 & 55 & 6/7/1990 & 1 & 2,306 & -- \\
\hline 113 & 430825100025101 & 96N78W10DDDD & 2,288 & -- & $10 / 1 / 2001$ & 1 & 2,278 & R2-2001-55 \\
\hline 114 & 430648100022401 & 96N78W23CD & 2,244 & 42 & $11 / 10 / 2000$ & 1 & 2,230 & -- \\
\hline 115 & 430512100071701 & $96 \mathrm{~N} 78 \mathrm{~W} 31 \mathrm{C}$ & 2,401 & 200 & $9 / 16 / 1988$ & 1 & 2,286 & -- \\
\hline 116 & 430920100100001 & 96N79W 3DDDD & 2,300 & -- & 7/27/1999 & 1 & 2,285 & R20-99-42 \\
\hline 117 & 430816100095701 & 96N79W14BBCC & 2,240 & -- & $5 / 20 / 1997$ & 1 & 2,238 & R2-97-01 \\
\hline 118 & 430812100095901 & $96 \mathrm{~N} 79 \mathrm{~W} 14 \mathrm{BBCC} 2$ & 2,240 & 30 & 8/6/1997 & 1 & 2,237 & R20-97-38 \\
\hline 119 & 431304099140601 & 97N71W15CB & 2,022 & 60 & $9 / 2 / 2004$ & 1 & 2,014 & -- \\
\hline 120 & 431113099173801 & 97N71W30CCBA & 2,180 & 148 & $8 / 24 / 1988$ & 1 & 2,134 & R20-88-39 \\
\hline 121 & 431034099174501 & 97N71W31CBBB & 2,147 & 97 & $8 / 30 / 1988$ & 1 & 2,144 & R20-88-44 \\
\hline 122 & 431034099171101 & 97N71W31DBBB & 2,200 & 152 & $8 / 30 / 1988$ & 1 & 2,124 & R20-88-43 \\
\hline 123 & 431238099224101 & 97N72W20AA 1 & 2,169 & 72 & $12 / 2 / 1987$ & 1 & 2,148 & -- \\
\hline 124 & 431238099224102 & 97N72W20AA 2 & 2,169 & 40 & $5 / 3 / 1988$ & 1 & 2,146 & -- \\
\hline 125 & 431159099213001 & 97N72W21DD & 2,169 & 83 & $2 / 16 / 1996$ & 1 & 2,139 & -- \\
\hline 126 & 431153099212201 & 97N72W21DDDD & 2,150 & 53 & 11/13/1984-9/30/2009 & 175 & $2,145.2$ & GY-77A \\
\hline 127 & 431159099205501 & $97 N 72 W 22 C D$ & 2,148 & 70 & $10 / 15 / 1991$ & 1 & 2,126 & -- \\
\hline 128 & 431102099182501 & 97N72W25CDDD & 2,223 & 172 & $8 / 24 / 1988$ & 1 & 2,175 & $\mathrm{R} 20-88-40$ \\
\hline 129 & 431146099185001 & 97N72W25DC & 2,228 & 148 & $8 / 30 / 1989$ & 1 & 2,143 & -- \\
\hline 130 & 431146099200101 & 97N72W26BB & 2,143 & 55 & $6 / 20 / 1989$ & 1 & 2,134 & -- \\
\hline 131 & 431107099200101 & 97N72W26CC & 2,161 & 70 & $7 / 1 / 1992$ & 1 & 2,146 & -- \\
\hline 132 & 431101099211901 & 97N72W27DDDD & 2,163 & 56 & 11/13/1984-9/30/2009 & 175 & $2,152.9$ & $\mathrm{GY}-77 \mathrm{~B}$ \\
\hline 133 & 431047099195301 & 97N72W35BB 1 & 2,194 & 70 & $5 / 17 / 1990$ & 1 & 2,159 & -- \\
\hline 134 & 431047099195302 & 97N72W35BB 2 & 2,194 & 70 & $5 / 17 / 1990$ & 1 & 2,159 & -- \\
\hline 135 & 431052099174801 & 97N72W36AADA & 2,195 & 147 & $8 / 31 / 1988$ & 1 & 2,172 & $\mathrm{R} 20-88-45$ \\
\hline
\end{tabular}


Table S1-1. Selected data from wells used for mean potentiometric surface of the Ogallala aquifer for water years 1985-2009.-Continued [NGVD 29, National Geodetic Vertical Datum of 1929; --, not available]

\begin{tabular}{|c|c|c|c|c|c|c|c|c|}
\hline $\begin{array}{l}\text { Index } \\
\text { num- } \\
\text { ber } \\
\text { (fig. 6) }\end{array}$ & $\begin{array}{c}\text { Site identification } \\
\text { number }\end{array}$ & Legal location & $\begin{array}{l}\text { Land- } \\
\text { surface } \\
\text { altitude } \\
\text { (feet above } \\
\text { NGVD 29) }\end{array}$ & $\begin{array}{l}\text { Well } \\
\text { depth }\end{array}$ & $\begin{array}{l}\text { Hydraulic head } \\
\text { measurement date or } \\
\text { range of dates }\end{array}$ & $\begin{array}{c}\text { Number } \\
\text { of mea- } \\
\text { sure- } \\
\text { ments }\end{array}$ & $\begin{array}{c}\text { Mean } \\
\text { measured } \\
\text { hydraulic } \\
\text { head } \\
\text { (feet above } \\
\text { NGVD 29) }\end{array}$ & $\begin{array}{c}\text { Other } \\
\text { identifier }\end{array}$ \\
\hline 136 & 431055099181101 & 97N72W36ABAC & 2,222 & 164 & $8 / 24 / 1988$ & 1 & 2,176 & R20-88-41 \\
\hline 137 & 431054099183201 & 97N72W36BA & 2,235 & 150 & $8 / 15 / 1989$ & 1 & 2,157 & -- \\
\hline 138 & 431021099180601 & 97N72W36DD & 2,215 & 55 & 9/30/1999 & 1 & 2,180 & -- \\
\hline 139 & 431435099250401 & 97N73W 1DD & 2,167 & 50 & $6 / 30 / 1989$ & 1 & 2,157 & -- \\
\hline 140 & 431409099261501 & 97N73W11AD & 2,162 & 40 & $4 / 14 / 1989$ & 1 & 2,155 & -- \\
\hline 141 & 431422099255701 & 97N73W12BB & 2,178 & 63 & $10 / 20 / 2005$ & 1 & 2,169 & -- \\
\hline 142 & 431412099254501 & 97N73W12BD & 2,178 & 61 & $10 / 22 / 2005$ & 1 & 2,166 & -- \\
\hline 143 & 431047099314401 & 97N73W31BC 1 & 2,277 & 80 & $8 / 21 / 1989$ & 1 & 2,271 & -- \\
\hline 144 & 431116099331301 & 97N74W26DADA & 2,282 & -- & $6 / 26 / 2001$ & 1 & 2,272 & R20-2001-19 \\
\hline 145 & 431110099353401 & 97N74W27CCBB & 2,285 & 35 & $3 / 11 / 2002-8 / 7 / 2003$ & 4 & 2,262 & R20-99-35 a \\
\hline 146 & 431146099354401 & 97N74W28AA & 2,277 & 30 & $5 / 20 / 1991$ & 1 & 2,271 & -- \\
\hline 147 & 431028099374801 & $97 \mathrm{~N} 74 \mathrm{~W} 32 \mathrm{CB}$ & 2,290 & 22 & $3 / 25 / 1989$ & 1 & 2,282 & -- \\
\hline 148 & 431435099460601 & 97N75W 6CC & 2,328 & 41 & $7 / 21 / 2001$ & 2 & 2,313 & -- \\
\hline 149 & 431435099460602 & $97 \mathrm{~N} 75 \mathrm{~W} 6 \mathrm{CC} 2$ & 2,328 & 41 & $7 / 21 / 2001$ & 2 & 2,313 & -- \\
\hline 150 & 431343099454801 & 97N75W 7CD & 2,305 & 23 & $4 / 20 / 1990$ & 1 & 2,282 & -- \\
\hline 151 & 431107099421501 & 97N75W27CD & 2,249 & 60 & $10 / 30 / 1991$ & 1 & 2,228 & -- \\
\hline 152 & 431009099450001 & 97N75W32CCCC & 2,300 & 55 & $3 / 11 / 2002-8 / 7 / 2003$ & 4 & 2,276 & R2-2000-06 ${ }^{\mathrm{a}}$ \\
\hline 153 & 431009099424001 & 97N75W34CCCC & 2,292 & -- & 6/20/2001 & 1 & 2,280 & R20-2001-14 \\
\hline 154 & 431014099421501 & 97N75W34CD & 2,295 & 70 & $5 / 14 / 1991$ & 1 & 2,280 & -- \\
\hline 155 & 431009099413001 & 97N75W35CCCC 1 & 2,298 & -- & $6 / 18 / 2001$ & 1 & 2,295 & R20-2001-12 \\
\hline 156 & 431502099462401 & 97N76W 1AD & 2,317 & 36 & $12 / 5 / 2000$ & 1 & 2,313 & -- \\
\hline 157 & 431434099462401 & 97N76W 1DDDD & 2,341 & 45 & 11/13/1984-9/30/2009 & 173 & $2,323.3$ & TR-78G \\
\hline 158 & 431515099484601 & 97N76W 3AA & 2,256 & 46 & $5 / 7 / 1992$ & 1 & 2,248 & -- \\
\hline 159 & 431519099520301 & 97N76W 5BBBA & 2,264 & 42 & 11/13/1984-9/30/2009 & 172 & $2,257.3$ & TR-72E \\
\hline 160 & 431502099523701 & 97N76W 6AC 1 & 2,272 & 60 & $3 / 1 / 2000$ & 1 & 2,262 & -- \\
\hline 161 & 431449099521901 & 97N76W 6CC & 2,284 & 45 & $5 / 22 / 1990$ & 1 & 2,269 & -- \\
\hline 163 & 431403099521301 & 97N76W 7DAAA & 2,370 & -- & $5 / 20 / 2003$ & 1 & 2,305 & R2-2003-11 \\
\hline 162 & 431404099521701 & 97N76W 7DAAA 1 & 2,370 & 142 & $7 / 22 / 2003$ & 1 & 2,307 & R2-2003-12 \\
\hline 164 & 431403099524801 & 97N76W 7DBBB & 2,337 & 98 & $7 / 22 / 2003$ & 1 & 2,307 & R2-2003-07a \\
\hline 165 & 431410099490401 & 97N76W10AC & 2,392 & 130 & $7 / 10 / 2003$ & 1 & 2,316 & -- \\
\hline 166 & 431252099465901 & 97N76W13CD & 2,373 & 46 & $7 / 15 / 1989$ & 1 & 2,348 & -- \\
\hline 167 & 431330099484501 & 97N76W15AABA & 2,332 & 85 & 11/13/1984-9/30/2009 & 175 & $2,327.4$ & TR-78H \\
\hline 168 & 431336099510001 & 97N76W16BBBB & 2,420 & 163 & $3 / 11 / 2002-8 / 7 / 2003$ & 4 & 2,329 & R20-2001-08 \\
\hline 169 & 431334099520701 & 97N76W17BBBB 1 & 2,398 & 165 & 11/13/1984-9/30/2009 & 174 & $2,323.1$ & TR-78A \\
\hline 170 & 431312099524801 & 97N76W18ACCC 1 & 2,433 & -- & $5 / 7 / 2003$ & 1 & 2,324 & R2-2003-04 \\
\hline
\end{tabular}


Table S1-1. Selected data from wells used for mean potentiometric surface of the Ogallala aquifer for water years 1985-2009.—Continued [NGVD 29, National Geodetic Vertical Datum of 1929; --, not available]

\begin{tabular}{|c|c|c|c|c|c|c|c|c|}
\hline $\begin{array}{l}\text { Index } \\
\text { num- } \\
\text { ber } \\
\text { (fig. 6) }\end{array}$ & $\begin{array}{c}\text { Site identification } \\
\text { number }\end{array}$ & Legal location & $\begin{array}{l}\text { Land- } \\
\text { surface } \\
\text { altitude } \\
\text { (feet above } \\
\text { NGVD 29) }\end{array}$ & $\begin{array}{l}\text { Well } \\
\text { depth }\end{array}$ & $\begin{array}{l}\text { Hydraulic head } \\
\text { measurement date or } \\
\text { range of dates }\end{array}$ & $\begin{array}{c}\text { Number } \\
\text { of mea- } \\
\text { sure- } \\
\text { ments }\end{array}$ & $\begin{array}{c}\text { Mean } \\
\text { measured } \\
\text { hydraulic } \\
\text { head } \\
\text { (feet above } \\
\text { NGVD 29) }\end{array}$ & $\begin{array}{c}\text { Other } \\
\text { identifier }\end{array}$ \\
\hline 171 & 431313099524802 & 97N76W18ACCC 2 & 2,433 & 172 & $7 / 22 / 2003$ & 1 & 2,324 & R2-2003-05 \\
\hline 173 & 431338099525001 & 97N76W18BAAA & 2,409 & -- & $5 / 6 / 2003$ & 1 & 2,319 & R2-2003-02 \\
\hline 172 & 431338099525101 & 97N76W18BAAA 1 & 2,409 & 162 & $7 / 22 / 2003$ & 1 & 2,319 & R2-2003-03 \\
\hline 174 & 431318099531301 & 97N76W18BC & 2,432 & 254 & $10 / 6 / 2004$ & 1 & 2,344 & -- \\
\hline 175 & 431248099532301 & 97N76W18CCCC & 2,454 & 300 & $7 / 22 / 2003$ & 1 & 2,332 & R2-2003-16 ${ }^{\mathrm{a}}$ \\
\hline 176 & 431246099524701 & 97N76W18CDDD & 2,461 & -- & $5 / 28 / 2003$ & 1 & 2,314 & R2-2003-17 \\
\hline 177 & 431310099521301 & 97N76W18DAAA & 2,408 & -- & $5 / 13 / 2003$ & 1 & 2,337 & R2-2003-08 \\
\hline 178 & 431311099521401 & 97N76W18DAAA 2 & 2,408 & 182 & $7 / 22 / 2003$ & 1 & 2,337 & R2-2003-10 \\
\hline 179 & 431239099531301 & 97N76W19BB & 2,447 & 195 & $11 / 17 / 1986$ & 1 & 2,327 & -- \\
\hline 180 & 431226099531302 & 97N76W19BC & 2,405 & 126 & $7 / 11 / 1990$ & 1 & 2,338 & -- \\
\hline 181 & 431156099521701 & 97N76W19DDDD 2 & 2,390 & 168 & 11/13/1984-9/30/2009 & 174 & $2,342.8$ & TR-78B \\
\hline 182 & 431245099513701 & 97N76W20BAAA & 2,419 & 142 & $7 / 22 / 2003$ & 1 & 2,342 & R2-2003-22 ${ }^{\mathrm{a}}$ \\
\hline 183 & 431239099520101 & 97N76W20BB & 2,448 & 180 & $8 / 24 / 1998$ & 1 & 2,343 & -- \\
\hline 184 & 431244099521001 & 97N76W20BBBB & 2,446 & -- & $6 / 4 / 2003$ & 1 & 2,337 & R2-2003-23 \\
\hline 185 & 431220099521101 & 97N76W20BCCC & 2,463 & 182 & $7 / 22 / 2003$ & 1 & 2,342 & R2-2000-19a \\
\hline 186 & 431220099513601 & 97N76W20BDDD & 2,455 & -- & $6 / 3 / 2003$ & 1 & 2,344 & R2-2003-20 \\
\hline 187 & 431239099501501 & $97 N 76 W 21 A B$ & 2,418 & 100 & $8 / 29 / 2002$ & 1 & 2,377 & -- \\
\hline 188 & 431156099472601 & 97N76W23DDDD & 2,362 & 65 & 11/13/1984-9/30/2009 & 176 & $2,355.8$ & TR-78I \\
\hline 189 & 431239099465901 & 97N76W24AB & 2,383 & 60 & $10 / 25 / 1996$ & 1 & 2,367 & -- \\
\hline 190 & 431107099482801 & 97N76W26C & 2,352 & 58 & $10 / 4 / 1991$ & 1 & 2,338 & -- \\
\hline 191 & 431102099505801 & 97N76W28CCCC & 2,348 & 125 & $3 / 11 / 2002-8 / 7 / 2003$ & 4 & 2,340 & R20-99-37 \\
\hline 192 & 431146099512601 & 97N76W29AB & 2,404 & 58 & $8 / 2 / 1990$ & 1 & 2,391 & -- \\
\hline 193 & 431146099520101 & 97N76W29BB & 2,402 & 110 & 8/6/1992 & 1 & 2,360 & -- \\
\hline 194 & 431041099510801 & 97N76W32AD & 2,331 & 66 & $11 / 1 / 1988$ & 1 & 2,322 & -- \\
\hline 195 & 431436099534801 & 97N77W 1DC & 2,294 & 80 & $10 / 4 / 2000$ & 1 & 2,289 & -- \\
\hline 196 & 431436099544101 & 97N77W 2DD & 2,342 & 92 & $8 / 17 / 2001$ & 1 & 2,289 & -- \\
\hline 197 & 431344099534801 & 97N77W12DC 1 & 2,339 & 200 & 8/8/1994 & 1 & 2,322 & -- \\
\hline 198 & 431339099534101 & 97N77W12DCDD & 2,340 & -- & 7/27/1992 & 1 & 2,298 & R20-92-24 \\
\hline 199 & 431338099543201 & 97N77W13BBBB 1 & 2,362 & 141 & $7 / 22 / 2003$ & 1 & 2,327 & R2-2003-14a \\
\hline 200 & 431338099543301 & 97N77W13BBBB & 2,362 & -- & $5 / 21 / 2003$ & 1 & 2,327 & R2-2003-13 \\
\hline 201 & 431436099545901 & 97N77W13BD & 2,383 & 286 & $10 / 7 / 2004$ & 1 & 2,281 & -- \\
\hline 202 & 431315099540001 & 97N77W13BDDA & 2,410 & -- & $5 / 21 / 2003$ & 1 & 2,325 & R2-2003-15 \\
\hline 203 & 431312099550801 & 97N77W14DD & 2,381 & 160 & $7 / 10 / 1997$ & 1 & 2,296 & -- \\
\hline 204 & 431337099555301 & 97N77W15AAAB & 2,393 & -- & $6 / 12 / 2001$ & 1 & 2,316 & R20-2001-09 \\
\hline 205 & 431239099575701 & 97N77W21BB 1 & 2,350 & 60 & 10/22/1991 & 1 & 2,340 & -- \\
\hline
\end{tabular}


Table S1-1. Selected data from wells used for mean potentiometric surface of the Ogallala aquifer for water years 1985-2009.-Continued [NGVD 29, National Geodetic Vertical Datum of 1929; --, not available]

\begin{tabular}{|c|c|c|c|c|c|c|c|c|}
\hline $\begin{array}{l}\text { Index } \\
\text { num- } \\
\text { ber } \\
\text { (fig. 6) }\end{array}$ & $\begin{array}{c}\text { Site identification } \\
\text { number }\end{array}$ & Legal location & $\begin{array}{l}\text { Land- } \\
\text { surface } \\
\text { altitude } \\
\text { (feet above } \\
\text { NGVD 29) }\end{array}$ & $\begin{array}{l}\text { Well } \\
\text { depth }\end{array}$ & $\begin{array}{l}\text { Hydraulic head } \\
\text { measurement date or } \\
\text { range of dates }\end{array}$ & $\begin{array}{l}\text { Number } \\
\text { of mea- } \\
\text { sure- } \\
\text { ments }\end{array}$ & $\begin{array}{c}\text { Mean } \\
\text { measured } \\
\text { hydraulic } \\
\text { head } \\
\text { (feet above } \\
\text { NGVD 29) }\end{array}$ & $\begin{array}{c}\text { Other } \\
\text { identifier }\end{array}$ \\
\hline 206 & 431239099575702 & 97N77W21BB 2 & 2,350 & 27 & $10 / 25 / 1991$ & 1 & 2,345 & -- \\
\hline 207 & 431154099574501 & 97N77W21CDCC & 2,371 & -- & $10 / 31 / 2000$ & 1 & 2,355 & R2-2000-84 \\
\hline 208 & 431200099564601 & 97N77W22DD & 2,331 & 31 & $7 / 24 / 1986$ & 1 & 2,325 & -- \\
\hline 209 & 431243099553601 & 97N77W23BBBB & 2,340 & 105 & 11/13/1984-9/30/2009 & 174 & $2,335.7$ & $\mathrm{TR}-78 \mathrm{C}$ \\
\hline 210 & 431213099533001 & 97N77W24DA & 2,389 & 120 & $9 / 12 / 1991$ & 1 & 2,329 & -- \\
\hline 211 & 431134099533001 & $97 N 77 W 25 \mathrm{~A}$ & 2,379 & 54 & 8/3/1989 & 1 & 2,367 & -- \\
\hline 212 & 431108099545901 & 97N77W26DC & 2,325 & 85 & $6 / 14 / 1993$ & 1 & 2,315 & -- \\
\hline 213 & 431055099570401 & 97N77W33AB & 2,331 & 42 & $10 / 26 / 1993$ & 1 & 2,317 & -- \\
\hline 214 & 431042099575701 & 97N77W33BA & 2,336 & 50 & $10 / 26 / 1993$ & 1 & 2,316 & -- \\
\hline 215 & 431026099573101 & 97N77W33CD & 2,340 & 113 & $10 / 20 / 2004$ & 1 & 2,317 & -- \\
\hline 216 & 431042099555301 & 97N77W34AD & 2,346 & 70 & $5 / 10 / 2001$ & 1 & 2,336 & -- \\
\hline 217 & 431016099564601 & 97N77W34CC & 2,394 & 77 & $10 / 4 / 2000$ & 1 & 2,330 & -- \\
\hline 218 & 431417100041901 & 97N78W 9AB & 2,367 & 34 & 10/27/1989 & 1 & 2,361 & -- \\
\hline 219 & 431253100072601 & 97N78W18CC & 2,409 & 62 & $11 / 4 / 1997$ & 1 & 2,379 & -- \\
\hline 220 & 431437100080201 & 97N79W 1DC 1 & 2,441 & 60 & $5 / 28 / 1986$ & 1 & 2,433 & -- \\
\hline 221 & 431437100080202 & 97N79W 1DC 2 & 2,441 & 52 & $1 / 7 / 1998$ & 1 & 2,439 & -- \\
\hline 222 & 431345100122801 & 97N79W 8DD & 2,562 & 144 & $12 / 7 / 1987$ & 1 & 2,482 & -- \\
\hline 223 & 431412100111601 & 97N79W 9AD & 2,507 & 60 & $8 / 16 / 2006$ & 1 & 2,495 & -- \\
\hline 224 & 431358100100601 & 97N79W10DA 1 & 2,468 & 175 & $4 / 28 / 2003$ & 1 & 2,439 & -- \\
\hline 225 & 431351100073501 & 97N79W12DDAA & 2,420 & -- & $6 / 21 / 2000$ & 1 & 2,381 & $\mathrm{R} 2-2000-21$ \\
\hline 226 & 431332100094801 & 97N79W14BB & 2,480 & 58 & $11 / 20 / 1987$ & 1 & 2,452 & -- \\
\hline 227 & 431337100095701 & 97N79W14BBBB & 2,462 & 77 & $3 / 11 / 2002-8 / 7 / 2003$ & 4 & 2,455 & $\mathrm{R} 2-2000-18^{\mathrm{a}}$ \\
\hline 228 & 431327100111001 & 97N79W16AADD & 2,606 & -- & $6 / 13 / 2000$ & 1 & 2,476 & R2-2000-14 \\
\hline 229 & 431327100111002 & 97N79W16AADD 2 & 2,606 & 173 & $3 / 11 / 2002-8 / 7 / 2003$ & 4 & 2,476 & $\mathrm{R} 2-2000-15^{\mathrm{a}}$ \\
\hline 230 & 431306100122801 & 97N79W17DA & 2,539 & 90 & 6/6/1994 & 1 & 2,474 & -- \\
\hline 231 & 431102100111001 & 97N79W33AAAA & 2,440 & -- & $6 / 19 / 2000$ & 1 & 2,399 & R2-2000-16 \\
\hline 232 & 431528099445501 & $98 \mathrm{~N} 75 \mathrm{~W} 32 \mathrm{CC}$ & 2,274 & 60 & $7 / 16 / 2004$ & 1 & 2,267 & -- \\
\hline 233 & 431711099510601 & 98N76W20DDDD & 2,231 & 70 & $11 / 13 / 1984-9 / 30 / 2009$ & 146 & $2,169.7$ & $\mathrm{TR}-72 \mathrm{~A}$ \\
\hline 234 & 431703099502901 & 98N76W28BAAA & 2,198 & 84 & 11/13/1984-9/30/2009 & 176 & $2,171.8$ & TR-72B \\
\hline 235 & 431714099510501 & 98N76W29DDAA & 2,231 & 57 & 11/13/1984-9/30/2009 & 172 & $2,216.4$ & $\mathrm{TR}-72 \mathrm{C}$ \\
\hline 236 & 431550099524501 & 98N76W31ACCC & 2,260 & 28 & $11 / 13 / 1984-9 / 30 / 2009$ & 164 & $2,248.8$ & $\mathrm{TR}-74 \mathrm{~A}$ \\
\hline 237 & 431553099525701 & 98N76W31BDCA & 2,282 & 118 & $11 / 13 / 1984-9 / 30 / 2009$ & 129 & $2,238.3$ & $\mathrm{TR}-72 \mathrm{~F}$ \\
\hline 238 & 431553099524602 & 98N76W31BDDB 2 & 2,265 & -- & 11/13/1984-9/30/2009 & 130 & $2,231.2$ & $\mathrm{TR}-72 \mathrm{G}$ \\
\hline 239 & 431553099525503 & 98N76W31BDDB 3 & 2,265 & -- & $11 / 13 / 1984-9 / 30 / 2009$ & 129 & $2,225.3$ & $\mathrm{TR}-72 \mathrm{H}$ \\
\hline 240 & 431528099522801 & 98N76W31DCBB & 2,263 & 29 & 11/13/1984-3/18/2009 & 159 & $2,257.1$ & $\mathrm{TR}-74 \mathrm{~F}$ \\
\hline
\end{tabular}


Table S1-1. Selected data from wells used for mean potentiometric surface of the Ogallala aquifer for water years 1985-2009.-Continued [NGVD 29, National Geodetic Vertical Datum of 1929; --, not available]

\begin{tabular}{|c|c|c|c|c|c|c|c|c|}
\hline $\begin{array}{l}\text { Index } \\
\text { num- } \\
\text { ber } \\
\text { (fig. 6) }\end{array}$ & $\begin{array}{c}\text { Site identification } \\
\text { number }\end{array}$ & Legal location & $\begin{array}{c}\text { Land- } \\
\text { surface } \\
\text { altitude } \\
\text { (feet above } \\
\text { NGVD 29) }\end{array}$ & $\begin{array}{l}\text { Well } \\
\text { depth }\end{array}$ & $\begin{array}{l}\text { Hydraulic head } \\
\text { measurement date or } \\
\text { range of dates }\end{array}$ & $\begin{array}{c}\text { Number } \\
\text { of mea- } \\
\text { sure- } \\
\text { ments }\end{array}$ & $\begin{array}{c}\text { Mean } \\
\text { measured } \\
\text { hydraulic } \\
\text { head } \\
\text { (feet above } \\
\text { NGVD 29) }\end{array}$ & $\begin{array}{c}\text { Other } \\
\text { identifier }\end{array}$ \\
\hline 241 & 431527099524501 & 98N76W31DCCC & 2,275 & 39 & 11/13/1984-9/30/2009 & 173 & $2,253.4$ & TR-74E \\
\hline 242 & 431527099523001 & 98N76W31DCDD & 2,279 & 34 & $11 / 13 / 1984-9 / 30 / 2009$ & 201 & $2,258.2$ & TR-74D \\
\hline 243 & 431604099510401 & 98N76W32AADD & 2,241 & 63 & 11/14/1984-9/30/2009 & 172 & $2,221.8$ & TR-72D \\
\hline 244 & 431605099504001 & 98N76W33BACC & 2,230 & 65 & $11 / 14 / 1984-2 / 19 / 2008$ & 132 & $2,223.3$ & TR-75B \\
\hline 245 & 431528099473501 & 98N76W35DD & 2,281 & 55 & $8 / 5 / 2004$ & 1 & 2,275 & -- \\
\hline 246 & 431521099461501 & 98N76W36DDDD & 2,320 & -- & $6 / 6 / 2001$ & 1 & 2,302 & R20-2001-06 \\
\hline 247 & 431621100035201 & 98N78W27CC & 2,452 & 75 & $12 / 13 / 2001$ & 1 & 2,421 & -- \\
\hline 248 & 431621100042801 & 98N78W28DC & 2,452 & 75 & $12 / 13 / 2001$ & 1 & 2,429 & -- \\
\hline 249 & 431608100051101 & 98N78W33BBBB & 2,430 & 78 & 11/14/1984-9/30/2009 & 177 & $2,416.7$ & TR-78D \\
\hline 250 & 431555100050301 & 98N78W33BC & 2,439 & 82 & $12 / 18 / 1993$ & 1 & 2,409 & -- \\
\hline 251 & 431533100051201 & 98N78W33CCBB & 2,421 & -- & $10 / 25 / 2000$ & 1 & 2,390 & R2-2000-78 \\
\hline 252 & 431542100025901 & 98N78W34DA & 2,414 & 55 & $1 / 20 / 1992$ & 1 & 2,389 & -- \\
\hline 253 & 431546100025101 & 98N78W34DAAA & 2,420 & -- & 6/14/1999 & 1 & 2,380 & R20-99-19 \\
\hline 254 & 431608100020501 & 98N78W35AB & 2,422 & 55 & $10 / 3 / 1990$ & 1 & 2,398 & -- \\
\hline 255 & 431759100110801 & $98 \mathrm{~N} 79 \mathrm{~W} 15 \mathrm{CCCC}$ & 2,406 & -- & $6 / 6 / 2000$ & 1 & 2,382 & R2-2000-10 \\
\hline 256 & 431615100110801 & 98N79W34BBBB & 2,522 & -- & $6 / 7 / 2000$ & 1 & 2,469 & R2-2000-11 \\
\hline 257 & 431615100110802 & 98N79W34BBBB 2 & 2,522 & 95 & 3/11/2002-8/7/2003 & 4 & 2,469 & $\mathrm{R} 2-2000-12^{\mathrm{a}}$ \\
\hline 258 & 431529100104101 & 98N79W34CC & 2,469 & 50 & $6 / 25 / 1990$ & 1 & 2,459 & -- \\
\hline 259 & 431523100110801 & 98N79W34CCCC & 2,493 & 75 & $3 / 11 / 2002-8 / 7 / 2003$ & 4 & 2,456 & $\mathrm{R} 2-2000-04^{\mathrm{a}}$ \\
\hline 260 & 431523100095701 & 98N79W34DDDD & 2,493 & 78 & $3 / 11 / 2002-8 / 7 / 2003$ & 4 & 2,445 & $\mathrm{R} 2-2000-20^{\mathrm{a}}$ \\
\hline 261 & 431529100091201 & 98N79W35DC & 2,493 & 100 & $5 / 29 / 1986$ & 1 & 2,471 & -- \\
\hline
\end{tabular}




\section{Supplement 2. Estimates of Transmissivity and Hydraulic Conductivity from Specific Capacity Data}

Data from five production wells (table 3) were analyzed to determine transmissivity values for the Ogallala aquifer. Specific capacity tests, where the well was pumped at a constant rate and the drawdown was measured after 1 to 39 hours, were conducted on 88 wells when they were completed (table S2-1). Well construction data included saturated thickness, well radius, pumping rate, drawdown, and pumping period. The specific yield, which is the storage term for unconfined aquifers, was assumed to be 0.036 because typical values range from 0.01 to 0.30 for unconfined aquifers (Freeze and Cherry, 1979).

Table S2-1. Specific capacity data, transmissivity, and hydraulic conductivity for selected wells completed in the Ogallala aquifer in the study area.

\begin{tabular}{|c|c|c|c|c|c|c|c|}
\hline $\begin{array}{c}\text { Index } \\
\text { number } \\
\text { (fig. 10) }\end{array}$ & $\begin{array}{l}\text { Discharge rate } \\
\text { (gallons per } \\
\text { minute) }\end{array}$ & $\begin{array}{c}\text { Drawdown } \\
\text { (feet) }\end{array}$ & $\begin{array}{l}\text { Pumping time } \\
\text { (hours) }\end{array}$ & $\begin{array}{l}\text { Well radius } \\
\text { (inches) }\end{array}$ & $\begin{array}{c}\text { Specific capacity } \\
\text { (gallons per minute } \\
\text { per foot of drawdown) }\end{array}$ & $\begin{array}{c}\text { Transmissivity } \\
\text { (square feet } \\
\text { per day) }\end{array}$ & $\begin{array}{c}\text { Hydraulic } \\
\text { conductivity } \\
\text { (feet per day) }\end{array}$ \\
\hline 1 & 20 & 13 & 12 & 2 & 1.54 & 300 & 9.1 \\
\hline 3 & 2 & 4 & 2 & 2 & 0.50 & 73.0 & 1.7 \\
\hline 4 & 30 & 16 & 1 & 2 & 1.88 & 294 & 11.3 \\
\hline 5 & 3 & 22 & 2 & 2 & 0.14 & 16.8 & 0.3 \\
\hline 6 & 15 & 74 & 1 & 2 & 0.20 & 24.0 & 0.5 \\
\hline 7 & 20 & 49 & 1 & 2 & 0.41 & 53.3 & 0.9 \\
\hline 8 & 20 & 71 & 1 & 2 & 0.28 & 34.9 & 0.7 \\
\hline 9 & 25 & 30 & 2 & 2 & 0.83 & 129 & 1.8 \\
\hline 10 & 10 & 3 & 1 & 2.5 & 3.33 & 529 & 18.9 \\
\hline 14 & 125 & 18 & 39 & 3 & 7.07 & 1,600 & 26.7 \\
\hline 15 & 20 & 3 & 1 & 2.5 & 6.67 & 1,140 & 19.9 \\
\hline 16 & 7 & 10 & 2 & 2 & 0.70 & 106 & 2.3 \\
\hline 17 & 2 & 65 & 1 & 2 & 0.03 & 2.59 & 0.3 \\
\hline 18 & 10 & 2 & 1 & 12 & 5.00 & 558 & 37.2 \\
\hline 19 & 32 & 5 & 2 & 2 & 6.40 & 1,210 & 43.2 \\
\hline 20 & 30 & 2 & 3 & 2 & 15.00 & 3,150 & 286 \\
\hline 21 & 7 & 12 & 2 & 2.5 & 0.58 & 82.2 & 1.6 \\
\hline 22 & 5 & 10 & 24 & 2 & 0.50 & 93.9 & 4.3 \\
\hline 23 & 15 & 14 & 1.5 & 2.5 & 1.09 & 159 & 8.9 \\
\hline 30 & 10 & 5 & 3 & 2 & 2.00 & 352 & 5.4 \\
\hline 31 & 15 & 12 & 1 & 2 & 1.25 & 187 & 4.0 \\
\hline 32 & 33 & 10 & 2 & 2 & 3.30 & 587 & 15.0 \\
\hline 33 & 62 & 38 & 12 & 6 & 1.63 & 260 & 2.5 \\
\hline 34 & 20 & 24 & 2 & 2 & 0.83 & 129 & 1.3 \\
\hline 35 & 15 & 6 & 1 & 2 & 2.50 & 404 & 8.6 \\
\hline
\end{tabular}


Table S2-1. Specific capacity data, transmissivity, and hydraulic conductivity for selected wells completed in the Ogallala aquifer in the study area.-Continued

\begin{tabular}{|c|c|c|c|c|c|c|c|}
\hline $\begin{array}{l}\text { Index } \\
\text { number } \\
\text { (fig. 10) }\end{array}$ & $\begin{array}{c}\text { Discharge rate } \\
\text { (gallons per } \\
\text { minute) }\end{array}$ & $\begin{array}{l}\text { Drawdown } \\
\text { (feet) }\end{array}$ & $\begin{array}{l}\text { Pumping time } \\
\text { (hours) }\end{array}$ & $\begin{array}{c}\text { Well radius } \\
\text { (inches) }\end{array}$ & $\begin{array}{c}\text { Specific capacity } \\
\text { (gallons per minute } \\
\text { per foot of drawdown) }\end{array}$ & $\begin{array}{c}\text { Transmissivity } \\
\text { (square feet } \\
\text { per day) }\end{array}$ & $\begin{array}{c}\text { Hydraulic } \\
\text { conductivity } \\
\text { (feet per day) }\end{array}$ \\
\hline 36 & 35 & 10 & 1 & 2 & 3.50 & 585 & 58.5 \\
\hline 37 & 20 & 9 & 2 & 2.5 & 2.22 & 364 & 9.6 \\
\hline 38 & 72 & 35 & 12 & 6 & 2.06 & 335 & 7.8 \\
\hline 39 & 15 & 13 & 1 & 2 & 1.15 & 171 & 1.5 \\
\hline 40 & 10 & 75 & 2 & 3 & 0.13 & 14.5 & 0.3 \\
\hline 41 & 35 & 40 & 2 & 3 & 0.88 & 124 & 2.9 \\
\hline 42 & 15 & 15 & 2 & 2 & 1.00 & 158 & 1.2 \\
\hline 43 & 15 & 7 & 1 & 2 & 2.14 & 340 & 10.0 \\
\hline 44 & 37 & 43 & 2 & 3 & 0.86 & 122 & 2.1 \\
\hline 45 & 30 & 35 & 2 & 2 & 0.86 & 133 & 2.3 \\
\hline 46 & 20 & 27 & 2 & 2 & 0.74 & 113 & 1.0 \\
\hline 47 & 15 & 11 & 1 & 2 & 1.36 & 206 & 1.6 \\
\hline 48 & 20 & 20 & 2 & 2 & 1.00 & 158 & 1.6 \\
\hline 49 & 30 & 32 & 26 & 2 & 0.94 & 187 & 1.8 \\
\hline 50 & 4 & 18 & 3 & 2 & 0.22 & 30.9 & 1.9 \\
\hline 51 & 15 & 5 & 1 & 2 & 3.00 & 494 & 13.7 \\
\hline 52 & 15 & 16 & 2 & 2 & 0.94 & 147 & 1.5 \\
\hline 53 & 10 & 5 & 2 & 2 & 2.00 & 339 & 9.2 \\
\hline 54 & 10 & 25 & 2 & 2 & 0.40 & 56.8 & 5.7 \\
\hline 55 & 25 & 41 & 1 & 15 & 0.61 & 39.0 & 3.9 \\
\hline 56 & 18 & 5 & 1 & 2 & 3.60 & 604 & 11.6 \\
\hline 57 & 30 & 15 & 3 & 2 & 2.00 & 352 & 3.5 \\
\hline 58 & 750 & 65 & 24 & 8 & 11.54 & 2,240 & 20.2 \\
\hline 59 & 500 & 60 & 4 & 6 & 8.33 & 1,400 & 26.4 \\
\hline 60 & 720 & 30 & 24 & 8 & 24.00 & 4,950 & 31.3 \\
\hline 61 & 225 & 60 & 10 & 6 & 3.75 & 638 & 26.6 \\
\hline 62 & 900 & 139 & 20 & 6 & 6.47 & 1,240 & 15.1 \\
\hline 63 & 12 & 6 & 1.5 & 2 & 2.00 & 329 & 7.5 \\
\hline 64 & 225 & 65 & 10 & 6 & 3.46 & 584 & 34.4 \\
\hline 65 & 35 & 34 & 1 & 2 & 1.03 & 151 & 2.6 \\
\hline 66 & 8 & 19 & 1 & 2 & 0.42 & 55.2 & 1.6 \\
\hline 67 & 12 & 5 & 1.5 & 2 & 2.40 & 402 & 12.6 \\
\hline 68 & 45 & 23 & 1 & 15 & 1.96 & 169 & 15.4 \\
\hline 69 & 45 & 46 & 1 & 15 & 0.98 & 71.7 & 6.5 \\
\hline 70 & 780 & 109 & 12 & 8 & 7.13 & 1,240 & 22.6 \\
\hline 71 & 10 & 10 & 2 & 2 & 1.00 & 158 & 13.1 \\
\hline 72 & 700 & 98 & 24 & 8 & 7.14 & 1,330 & 41.5 \\
\hline 73 & 25 & 17 & 2 & 2 & 1.47 & 242 & 6.2 \\
\hline 74 & 10 & 5 & 1 & 2 & 2.00 & 315 & 5.8 \\
\hline 75 & 8.5 & 38 & 4 & 2 & 0.22 & 32.2 & 3.2 \\
\hline 76 & 6 & 30 & 2 & 2 & 0.20 & 26.0 & 2.6 \\
\hline
\end{tabular}


Table S2-1. Specific capacity data, transmissivity, and hydraulic conductivity for selected wells completed in the Ogallala aquifer in the study area.-Continued

\begin{tabular}{|c|c|c|c|c|c|c|c|}
\hline $\begin{array}{l}\text { Index } \\
\text { number } \\
\text { (fig. 10) }\end{array}$ & $\begin{array}{c}\text { Discharge rate } \\
\text { (gallons per } \\
\text { minute) }\end{array}$ & $\begin{array}{l}\text { Drawdown } \\
\text { (feet) }\end{array}$ & $\begin{array}{l}\text { Pumping time } \\
\text { (hours) }\end{array}$ & $\begin{array}{l}\text { Well radius } \\
\text { (inches) }\end{array}$ & $\begin{array}{c}\text { Specific capacity } \\
\text { (gallons per minute } \\
\text { per foot of drawdown) }\end{array}$ & $\begin{array}{l}\text { Transmissivity } \\
\text { (square feet } \\
\text { per day) }\end{array}$ & $\begin{array}{c}\text { Hydraulic } \\
\text { conductivity } \\
\text { (feet per day) }\end{array}$ \\
\hline 77 & 20 & 10 & 2 & 2 & 2.00 & 339 & 7.7 \\
\hline 78 & 35 & 12 & 1 & 2 & 2.92 & 479 & 8.1 \\
\hline 79 & 30 & 21 & 2 & 2 & 1.43 & 234 & 21.3 \\
\hline 80 & 25 & 11 & 3 & 2 & 2.27 & 405 & 6.2 \\
\hline 81 & 10 & 1 & 2 & 2 & 10.00 & 1,960 & 67.7 \\
\hline 82 & 8 & 4 & 2 & 2 & 2.00 & 339 & 7.5 \\
\hline 83 & 20 & 10 & 1 & 2 & 2.00 & 315 & 5.4 \\
\hline 84 & 256 & 127 & 4 & 8 & 2.02 & 271 & 4.7 \\
\hline 85 & 25 & 6 & 2 & 2 & 4.17 & 757 & 21.6 \\
\hline 86 & 15 & 6 & 1 & 2 & 2.50 & 404 & 7.8 \\
\hline 87 & 15 & 7 & 1 & 2 & 2.14 & 340 & 6.9 \\
\hline 88 & 10 & 15 & 2 & 2 & 0.67 & 101 & 1.4 \\
\hline
\end{tabular}

Transmissivity for the Ogallala aquifer was calculated using a form of the Theis and others (1963) nonequilibrium equation:

$$
S_{c}=\frac{4 \pi T}{\left[\ln \left(\frac{2.25 T t_{p}}{r_{w}^{2} S}\right)\right]},
$$

where

$S_{c} \quad$ is specific capacity, in gallons per day per foot of drawdown;

$T$ is transmissivity, in gallons per day per foot;

$t_{p} \quad$ is pumping time, in days;

$r_{w}^{p} \quad$ is the radius of the well, in feet; and

$S$ is storativity (dimensionless).

The Theis and others (1963) method used in this analysis probably is the most common way to analytically estimate transmissivity from specific capacity (Mace, 2001).

The assumptions behind equation S2-1 are that the well is fully penetrating, the porous media is homogeneous and isotropic, the well loss is negligible, and the effective radius is equal to the radius of the production well (Mace, 2001). The equation was solved iteratively by rearranging equation S2-1 to solve for transmissivity $(T)$ in the numerator (equation S2-2):

$$
T=\frac{S_{c}}{4 \pi} \ln \left(\frac{2.25 T t_{p}}{r_{w}^{2} S}\right) .
$$

Values for specific capacity $\left(S_{c}\right)$, pumping time $\left(t_{p}\right)$, and well radius $\left(r_{w}\right)$ were available from the well completion report, storage coefficient $(S)$ was based on previously published values (table 3 ), and an initial estimate for the $T$ in the numerator on the right side of equation S2-2 was used to calculate the $T$ on the left side of equation S2-2. The calculated $T$ was then substituted back into the numerator on the right side of equation $\mathrm{S} 2-2$, and this process was repeated using an iterative function until the $T$ on the left side was within 0.01 gallons per day per foot of the $T$ in the right side of equation $\mathrm{S} 2-2$. 


\section{Supplement 3. Analysis of Recharge and Evapotranspiration With a Soil-Water- Balance Method}

This supplement describes the use of a soil-water-balance (SWB) method using the SWB software program developed by Westenbroek and others (2010) to determine the amount of recharge available to the Ogallala aquifer and the evapotranspiration from the aquifer. Two recharge simulations were completed using the SWB program, and the mean outputs were aggregated for use in the numerical model as described in the "Recharge" section of this report.

The SWB program uses daily precipitation and temperature data along with land cover, soil type, root depth, and runoff flow direction data to calculate runoff, evapotranspiration, and recharge. The SWB program can account for frozen ground, snowfall, snowmelt, and the dependency of recharge on the timing and spatial distribution of precipitation. A modified Thornthwaite-Mather soil-water accounting (Westenbroek and others, 2010) is used to calculate recharge as follows:

$$
\text { recharge }=(\text { precipitation }+ \text { snowmelt }+ \text { inflow })-(\text { interception }+ \text { outflow }+E T)-\Delta(\text { soil moisture }),
$$

where precipitation, snowmelt, and inflow are sources; interception, outflow, and evapotranspiration (ET) are sinks; and $\Delta$ soil moisture is the change in soil moisture as the amount of water added to or lost from the soil, with the maximum set by the holding capacity of the soil and the minimum set by the wilting point.

Runoff is calculated through the following equation (Westenbroek and others, 2010):

$$
R=\frac{\left(P-I_{a}\right)^{2}}{\left(P+\left[S_{\max }-I_{a}\right]\right)},
$$

where

$$
\begin{aligned}
R & \text { is runoff, in inches; } \\
P & \text { is daily precipitation, in inches; } \\
I_{a} & \text { is initial abstraction, the amount of precipitation that must fall before any runoff is generated, in inches; and } \\
S_{\max } & \text { is maximum soil-moisture holding capacity, in inches. }
\end{aligned}
$$

Daily precipitation $(P)$ is greater than initial abstraction $\left(I_{a}\right)$. The parameter $I_{a}$ is related to maximum soil-moisture $\left(S_{\max }\right)$ through the following equation (Westenbroek and others, 2010):

$$
I_{a}=0.2 S_{\max } .
$$

The maximum soil-moisture $\left(S_{\max }\right)$ is based on the Natural Resources Conservation Service curve number (CN; Curve Number Work Group, 2004) for a soil using the following equation (Westenbroek and others, 2010):

$$
S_{\max }=\left(\frac{1,000}{C N}\right)-10 .
$$

Two separate simulations were made using different climate inputs for the SWB program, one for each of two climate stations. Daily climatic data from two National Oceanic and Atmospheric Administration climate stations (Winner and Gregory, S. Dak., stations 399367 and 393452, respectively) were used as the climatic inputs for each of two simulations using the SWB program (fig. 11; National Oceanic and Atmospheric Administration, 2010). Daily climatic data for water years 1975-2009 were used in the SWB model and included daily values for maximum and minimum temperature and total precipitation. Data for 1975-1984 were used as an initialization time period for the SWB program. Mean daily temperatures were calculated as the mean of the maximum and minimum daily values. For days of incomplete record, the mean precipitation for the month in which the missing record occurred and the mean daily precipitation during that month were used to create a synthetic precipitation record. One complete precipitation and temperature record for each station was used for two independent SWB model simulations, and outputs were averaged for input to MODFLOW_NWT. The precipitation data were in water-equivalent inches when the precipitation came in the form of snow (National Oceanic and Atmospheric Administration, 2010), and the SWB program used temperature data to determine when precipitation was snow (Westenbroek and others, 2010). The Hargreaves-Samani method of evapotranspiration calculation was chosen for use in the SWB program because only minimum, maximum, and mean temperature and precipitation data were required on a daily time step. 
The flow direction grid was created from a resampled 30-meter [m; 98-foot (ft)] digital elevation model (DEM) of the study area (U.S. Geological Survey, 2006). The 30-m DEM was resampled to the 500-m (1,640-ft) grid that was used for the numerical groundwater-flow model (fig. 14). The SWB model only allows runoff to flow in one direction from a cell (Westenbroek and others, 2010), so cells that could have multiple runoff directions from the resampled DEM were examined and modified. If the runoff could flow in opposite directions, the cell was assigned an arbitrary number that was used for all depression cells. All depressions were allowed to infiltrate water from runoff the day the runoff was generated, but any ponding was removed at the start of the next day. The continuous frozen ground index (in degree Celsius-days) was used to increase the runoff resulting from precipitation or snowmelt that occurs while the ground is frozen. Antecedent moisture conditions are considered from the previous 5 days.

The hydrologic soil groups were assigned the designations A, B, C, D, C/D, and A/D based on soil survey data (fig. S3-1; Natural Resources Conservation Service, 2009a). The infiltration rate of each hydrologic soil groups A, B, C, and D was limited by the vertical hydraulic conductivity estimates of Long and Putnam (2010) for the Ogallala aquifer. Soil group A has the highest infiltration rate, and soil groups $\mathrm{C}$ and $\mathrm{D}$ has the lowest infiltration rate. The infiltration rate of combination soil groups was calculated from the mean of the two soil groups that were mixed (table S3-1).

Land-cover data for 2006 were obtained from Multi-Resolution Land Characteristics Consortium (2010) as 30-m (98-ft) raster data. The most prevalent land cover (fig. 3) was selected for each 500-m (1,640-ft) model cell (fig. 14). Each land cover was assigned values for interception storage in the growing seasons (table S3-2). For the dormant season, interception storage was assumed to be negligible. The growing season was set as the period from April 7 to October 26 and corresponds to the last and first frost occurrences each year for the climate station at Gregory, S. Dak. (station 393452; South Dakota State University, 2011). Land cover and soil group were assigned to every cell in the model, and each combination of land cover and soil type was assigned a curve number and depth of root zone (table S3-2).

The curve number was identified for each soil type and land cover combination in the study area. Curve numbers were assigned based on classifications in the National Engineering Handbook (Curve Number Work Group, 2004). Land cover and soil group combinations were available for soil groups B, C, and D. Curve numbers for soil group A were determined by fitting a power trend function through the curve numbers plotted against soil groups $\mathrm{B}, \mathrm{C}$, and $\mathrm{D}$. The curve number for combination soil groups was calculated from the mean of the two soil groups that were mixed.

The root zone depths were assigned as identical for every soil, but varied by land cover using data compiled by Canadell and others (1996) and Westenbroek and others (2010) because data were not sufficient to further constrain the inputs. The SWB model uses available water capacity for each root zone category to calculate the maximum amount of water that the soil can hold in storage (Westenbroek and others, 2010). The Natural Resources Conservation Service soil survey for Gregory and Tripp Counties contained available water capacity ranges for each horizon in every soil type (Natural Resources Conservation Service, 2009b). The available water capacity ranges for each soil horizon were aggregated to determine a mean available water capacity for each individual soil type. The soil types were lumped according to hydrologic group, and the aggregate available water capacity data were averaged to generate one value per hydrologic group. 


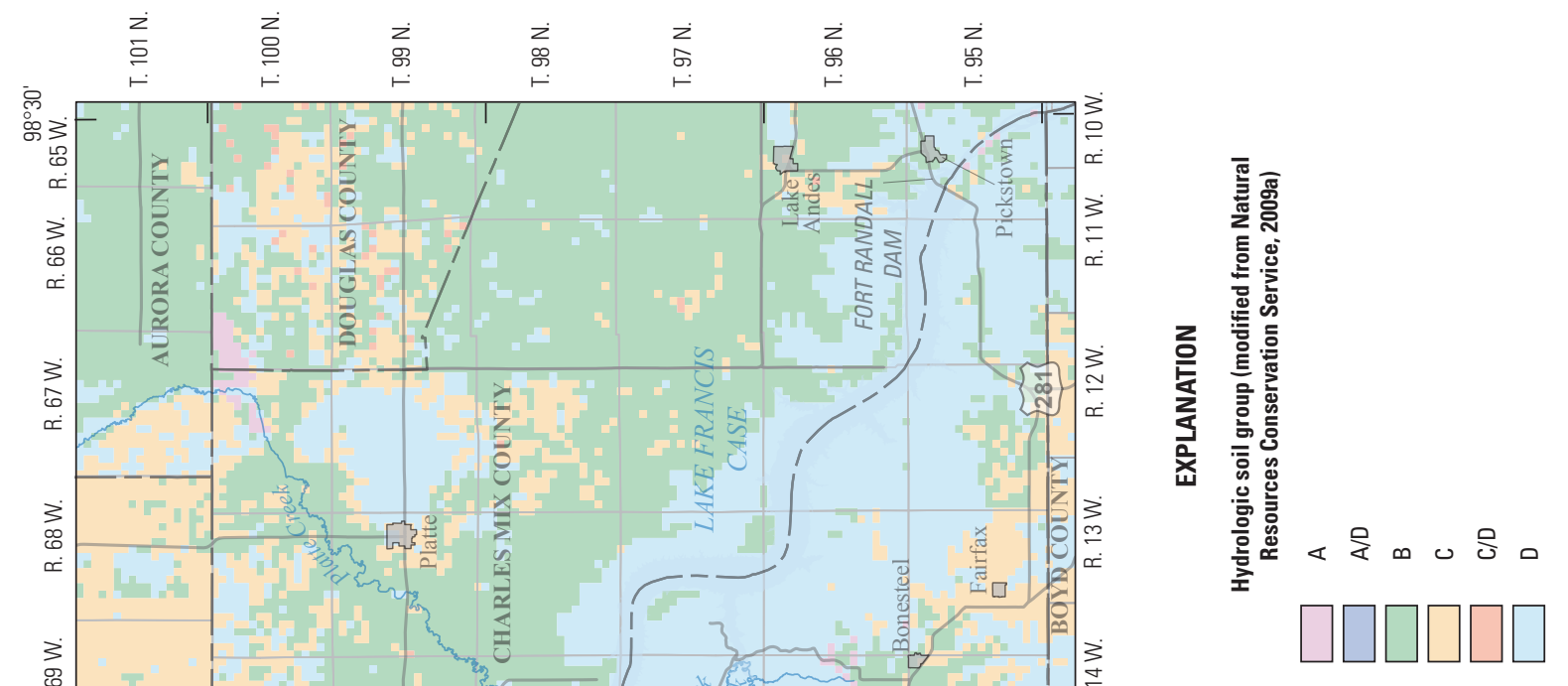

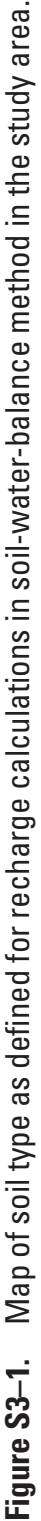


Table S3-1. Infiltration rates assigned by soil type.

[Soil type designations are from Natural Resources Conservation Service (2009a)]

\begin{tabular}{cccccc}
\hline \multicolumn{7}{c}{$\begin{array}{c}\text { Infiltration rate for soil type } \\
\text { (inches per day) }\end{array}$} \\
\hline A & AD & B & C & CD & D \\
\hline 7.20 & 4.26 & 1.88 & 1.32 & 1.32 & 1.32 \\
\hline
\end{tabular}

Table S3-2. Interception storage values and depth of root zone assigned by land-cover category.

[Land cover categories are from Multi-Resolution Land Characteristics Consortium (2010)]

\begin{tabular}{lcc}
\hline \multicolumn{1}{c}{ Land-cover category } & $\begin{array}{c}\text { Interception } \\
\text { storage, } \\
\text { in inches }\end{array}$ & $\begin{array}{c}\text { Depth of } \\
\text { root zone, } \\
\text { in feet }\end{array}$ \\
\hline Open water & 0.00 & 0.0 \\
Developed, open space & 0.06 & 2.0 \\
Developed, low intensity & 0.08 & 2.0 \\
Developed, medium intensity & 0.08 & 2.0 \\
Developed, high intensity & 0.08 & 2.0 \\
Deciduous forest & 0.09 & 4.5 \\
Evergreen forest & 0.11 & 5.5 \\
Herbaceous grassland & 0.09 & 4.0 \\
Pasture/hay & 0.09 & 4.0 \\
Cultivated crops & 0.09 & 3.5 \\
Woody wetlands & 0.05 & 4.5 \\
Emergent herbaceous wetlands & 0.00 & 2.0 \\
\hline
\end{tabular}


Publishing support provided by:

Pembroke and Rolla Publishing Service Centers

For more information concerning this publication, contact: Director, USGS South Dakota Water Science Center 1608 Mountain View Road

Rapid City, South Dakota 57702

(605) 394-3200

Or visit the South Dakota Water Science Center Web site at: http://sd.water.usgs.gov/ 
